Martín Dojčár

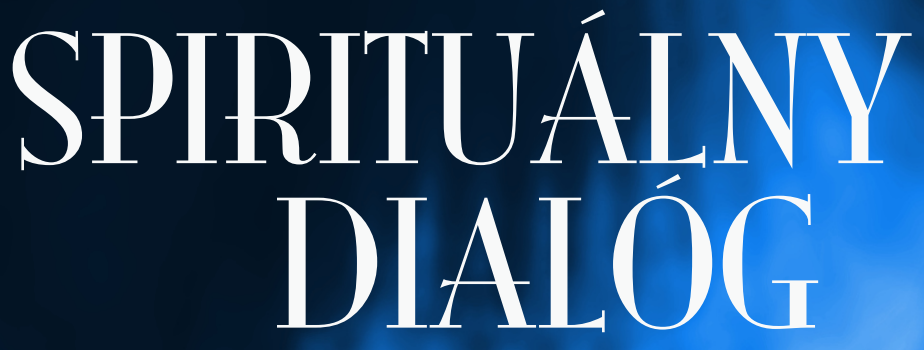




\section{Spirituálny dialóg}

Martin Dojčár 
(C) doc. PaedDr. Martin Dojčár, PhD., 2021

Návrh a grafický dizajn obálky

(C) MgA. Štefan Blažo, PhD.

Jazyková korektúra

PaedDr. Žofia Tkáčová

Typografické spracovanie

Ivan Janák

Recenzenti

prof. ThLic. Miloš Lichner SJ, D.Th.

prof. PhDr. Ing. Ladislav Bučko, PhD.

Monografia je výstupom z projektu Otvárame dvere medzináboženskému dialógu: Žalmy v židovsko-krestanskej tradicii (GR-00523B)

Vydavatel'

Teologická fakulta

Trnavskej univerzity v Trnave

Kostolná 1

81499 Bratislava

Prvé vydanie

Strán 118 - AH 4,30

DOI 10.31262/978-80-568-0414-8/2021

ISBN 978-80-568-0413-1 (print)

ISBN 978-80-568-0414-8 (online) 


\section{Obsah}



1 Planetárna civilizácia . . . . . . . . . . . 7

1.1 Sociálny aspekt globálneho spolužitia:

konflikt civilizácií . . . . . . . . . . . . . . . .9

1.2 Kultúrny aspekt globálneho spolužitia:

pluralistická paradigma postmoderny . . . . . . . . . . 12

1.3 Náboženský aspekt globálneho spolužitia:

postsekulárna spoločnost' . . . . . . . . . . . . . . . 14

1.4 Antropologický aspekt globálneho spolužitia:

alterita $\&$ identita . . . . . . . . . . . . . . 20

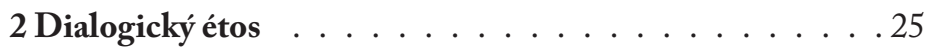

2.1 Komunikácia . . . . . . . . . . . . . . . 25

2.2 Dialóg ako forma komunikácie . . . . . . . . . . . . . . . 26

2.3 Dialóg ako interpersonálna udalost' . . . . . . . . . . 27

2.4 Dialogický spôsob existencie . . . . . . . . . . . . 29

2.5 Dialogický model medzináboženských vztahov . . . . 30

2.6 Dialóg ako forma ohlasovania . . . . . . . . . . 35

2.7 Záver . . . . . . . . . . . . . . . . . . 40

3 Perspektívy medzináboženského dialógu . . . . . . . . . 41

3.1 Perspektívy katolícko-hinduistického dialógu . . . . . 41

3.1.1 Náčrt dejín krestanskej misie v Indii . . . . . . . 42

3.1.2 Obrat k dialógu . . . . . . . . . . . . . .46

3.2 Perspektívy katolícko-buddhistického dialógu . . . . . 49 
3.2.1 Historický prierez vzájomných vztahov . . . . . . 49

3.2.2 Spoločné putovanie . . . . . . . . . . . . . . . . . 53 55

3.3 Perspektívy katolícko-židovského dialógu . . . . . . . 55

3.3.1 Dejiny konfliktu . . . . . . . . . . . . . . . . . . . . . 55

3.3.2 Obrat od konfliktu k dialógu . . . . . . . . . . . . . . . . 67

3.4 Perspektívy katolícko-moslimského dialógu . . . . . . 61

3.5 Záver . . . . . . . . . . . . . . . . 67

4 Spirituálny dialóg . . . . . . . . . . . . . . . . . . 69

4.1 Doktrinálne ukotvenie spirituálneho dialógu

v učení Magistéria . . . . . . . . . . . . . . 70

4.2 Hlavné rysy spirituálneho dialógu

v podaní Huga M. Enomiya-Lassalleho . . . . . . . . . 72

4.3 Diskusia k univerzálnej povahe

transcendentnej „skúsenosti“ . . . . . . . . . . . . . . . . . . . . . . . . . . . . .

4.4 Záver . . . . . . . . . . . . . . . . 88

5 Mystika - styčný bod spirituálneho dialógu . . . . . . . 91

5.1 Mystické jadro náboženstva . . . . . . . . . . . . . . . 92

5.2 Morfológia mystickej skúsenosti . . . . . . . . . . 994

5.3 Neintencionalita a fenomenálna identita

mystickej kontemplácie . . . . . . . . . . . . . . 999

Záver . . . . . . . . . . . . . . . 103

Bibliografia . . . . . . . . . . 105

Register .................... 111 


\section{Úvod}

Bol január roku 2012. Mrazivý ako je pravidlom v oných končinách Severnej Ameriky, kde teploty klesajú hlboko pod nulu. Mohutná vrstva snehu zahalila krajinu ako čarovná prikrývka, sadla na strechy univerzitných budov, schovala ich plášte z červenej tehly, betónu a skla do svojho trblietavého závoja. Hladel som na jej krásu spoza vločiek na oknách môjho nového domova na brehu jazera Stumpf. Bol som hostom na inštitúte v Collegeville, v tom jedinečnom „laboratóriu dialógu“.

Tam sme sa stretli. A to bol vlastne hlavný dôvod mojej cesty.

William Skudlarek je mních, benediktín výnimočných kvalít - promótor dialógu medzi stúpencami rôznych náboženstiev, medzi nasledovníkmi rôznych spiritualít; generálny sekretár Mnišskeho medzináboženského dialógu (DIMMID), inštitucionálneho lídra dialógu medzi náboženstvami, organizujúceho z poverenia Pápežskej rady pre medzináboženský dialóg unikátne dialogické stretnutia mníchov a mníšok odlišných náboženských tradícií, ktoré svojím účastníkom ponúkajú participáciu na duchovnej praxi partnerov v dialógu a vzájomné zdielanie vlastných duchovných skúseností.

Bol to môj prvý osobný kontakt s predstavitelom spirituálneho dialógu. Rozšíril môj obzor o svedectvo z praxe, doplnil mozaiku poznania dialógu duchovnej skúsenosti, ktorú som roky skladal z úlomkov životných príbehov 
jeho velkých reprezentantov - Thomasa Mertona, Huga Makibi Enomiya-Lassalla, Jean-Marie Déchaneta, Eduarda a Míly Tomášových, a dalších priekopníkov tejto novej formy medzináboženského dialógu.

Kniha, ktorú beriete do rúk, je syntézou desiatok rokov angažovaného bádania autora, jeho poznávania tejto fascinujúcej podoby dialógu. Na pozadí aktuálnych výziev doby (kap. 1 Planetárna civilizácia) v nej nájdete náčrt kontúr spirituálneho dialógu (kap. 4 Spirituálny dialóg), zakomponovaný do celkového obrazu dialógu (kap. 2 Dialogický étos), ktorého podobu dokreslujú perspektívy dialógu v náboženskej oblasti (kap. 3 Perspektivy medzináboženského dialógu) a portréty, či skôr skice niektorých jeho významných osobností. Jednotlivé motívy autorovho obrazu spirituálneho dialógu sa napokon zbiehajú v centrálnom motíve, ktorým je preň mystika ako styčný bod dialógu duchovnej skúsenosti (kap. 5 Mystika-styčný bod spirituálneho dialógu).

Odkaz tejto knihy sa dá zhrnút do niekolkých slov: je to stretnutie a spoločné putovanie. A tým chce aj kniha predovšetkým byt: pozvaním na stretnutie a spoločné putovanie ludí rôznej náboženskej a duchovnej orientácie. 


\section{Planetárna civilizácia}

Nikoho už azda neprekvapuje pestrofarebné panoptikum etník, rás, kultúr a národov, čo defiluje ulicami našich miest a prevracia monokultúrny pohlad na svet naruby, málokto sa už v súčasnosti pozastaví nad kultúrnou a náboženskou rôznorodostou. Kultúrna pluralita sa ukazuje v celej svojej pestrosti a s ňou aj pluralita náboženská.

Zviditelnenie plurality je predovšetkým dielom globalizácie. A hoci je pluralita vždy prítomná, nejaví sa vždy problematická. Proces prelamovania hraníc medzi kultúrami a náboženstvami robí mnohost'len zjavnejšou - nevytvára ju nutne, iba ju komunikuje.

V globalizujúcom sa svete vstupujú tiež do vzájomného kontaktu jednotlivé náboženské a duchovné tradície. Navzdory pochybnostiam skeptikov, náboženstvo v nejakej forme nad’alej ostáva životným štýlom väčšiny ludstva. $\mathrm{Z}$ približne 7,3 miliardy obyvatelov našej planéty, podla zistení americkej sociologickej agentúry Pew Research Center z roku 2015, sa hlási okolo 2,3 miliárd ku krestanstvu (čo predstavuje $31,2 \%$ svetovej populácie) a dalších 1,8 miliárd (24,1\% svetovej populácie) deklaruje svoju príslušnost' $\mathrm{k}$ islamu; približne 1,1 miliardy ludí $(15,1 \%$ svetovej populácie) sa identifikuje $s$ hinduizmom, temer 500 miliónov s buddhizmom (6,9 \% svetovej populácie), zhruba 40 miliónov sa hlási ku kmeňovým náboženstvám (5,7 \% svetovej populácie) a asi 14,3 miliónov k judaizmu $(0,2 \%$ svetovej populácie). Početná skupina 1,2 miliardy 
(16 \% svetovej populácie) nedeklaruje príslušnost k žiadnemu vierovyznaniu. ${ }^{1}$

Prognóza agentúry Pew predpokladá, že do roku 2060 vzrastie svetová populácia o $32 \%$ na 9,6 miliárd ludí a súčasne s tým narastie aj populácia moslimov o $70 \%$ a krestanov o $31 \%$. Do roku 2060 by tak moslimovia mali tvorit $31 \%$ globálnej populácie, teda približne 3 miliardy ludí, kým krestania by mali predstavovat $32 \%$ svetovej populácie, teda 3,1 miliardy. Prognóza dalej predpokladá, že stúpne počet hinduistov o $27 \%$ na 1,4 miliardy, kým počet stúpencov buddhizmu klesne o $7 \%$ zo súčasných 500 miliónov na 462 miliónov.

Charakteristickým znakom globalizácie je to, že spája dovedna všetky oblasti života, nielen ekonomické a politické štruktúry, ale aj kultúrne, náboženské a duchovné fenomény. Svet sa stáva človeku čoraz stiesnenejším príbytkom, „globálnou dedinou“. Ludstvo je na ceste k „planetárnej civilizácii“. ${ }^{2}$

Velkou výzvou globalizácie je problém globálneho spolužitia. Na pozadí xenofóbie $\mathrm{v}$ rozmanitosti jej foriem, ktorá kde-tu prerastá do animozity, zoči-voči hrozbe terorizmu, čoby špecifickej forme totalitarizmu, sa s osobitnou naliehavostou aktualizuje odveký problém vzájomného porozumenia a dorozumenia. Za problémom globálneho spolužitia treba totiž hladat práve absenciu medziludského porozumenia a zlyhanie dorozumenia.

1 Pew Research Center 2017.

2 Liptay 2000, s. 6. Sporné je, či vyústením dejinnej dynamiky bude akási ,jednotná“ globálna civilizácia, alebo skôr diverzifikovaný multicivilizačný svet, ako je nám známy z dejín. 
Problém globálneho spolužitia je komplexný fenomén, ktorý má viacero aspektov. Pre našu monografickú štúdiu o spirituálnom dialógu majú zvláštny význam štyri: sociálny (politický), kultúrny, náboženský a antropologický aspekt globálneho spolužitia.

\subsection{Sociálny aspekt globálneho spolužitia: konflikt civilizácií}

Proti optimistickej vízii planetárnej, prípadne multikultúrnej civilizácie americký politológ Samuel P. Huntington poukazuje na hrozbu ,konfiktu civilizáciı“ ako najvýznamnejšieho faktora globálneho spolužitia v súčasnosti.

Huntington dôvodí dejinným vývojom: novoveký multipolárny svet národných vel’mocí západnej civilizácie sa v období studenej vojny (druhá polovica 20. storočia) rekonfiguroval do bipolárnej podoby ideologicko-antagonistických „táborov“ Východu a Západu, aby bol na jej sklonku vystriedaný novým typom svetového poriadku - multicivilizačným svetom, ktorý čerpá svoj inherentný dynamizmus z konfliktu kultúr, ako $\mathrm{z}$ nového historicko-dialektického fenoménu, nahrádzajúceho dominanciu konfliktov ideologickej, politickej či ekonomickej povahy, takých charakteristických pre predchádzajúce dejinné obdobia. „Súperenie velmoci vystriedal konfikt civilizácii,“" tvrdí Huntington. $\mathrm{V}$ novom geopolitickom poriadku „hlavnými aktérmi svetovébo diania nadalej zostávajú národné štáty" a "ich konanie určuje, rovnako ako v minulosti

3 Huntington 2001, s. 15. 
snaha, ziskat moc a bohatstvo", no tiež, na rozdiel od minulosti, aj „ich kultúrna orientácia, ich príbuznosti a rozdiely“. ${ }^{4}$

Od konca studenej vojny sa dominantnou spoločensko-politickou silou stala kultúra. Samuel Huntington si všimol, že "národy rozdelené ideológiou, ale spojené kultúrou, sa začinajú zjednocovat" (napr. zjednotenie Nemecka), kým spoločnosti zjednotené ideológiou, ale rozdelené kultúrou, sa rozpadajú (napr. Sovietsky zväz, Juhoslávia). ${ }^{5}$ Základným kritériom spolupráce a spojenectva je preto pre Huntingtona kultúrna príbuznost.

Pozorovanie a analýza dejinného vývoja vedú amerického politológa $\mathrm{k}$ záveru, že "v novom svete nebude dochádzat k najzávažnejšim, najuäčšim a najnebezpečnejšim konfliktom medzi spoločenskými triedami, medzi chudobnými a bohatými, či inak ekonomicky definovanými skupinami, ale medzi národmi patriacimi k rôznym kultúrnym entitám."6 To v konečnom dôsledku znamená, že „priestor“ stretnutia alebo konfliktu bude, či skôr je, vymedzený hranicami civilizácií.

Pre Hungtintona civilizácia nie je $\mathrm{v}$ zásade odlišná od kultúry - „ivilizácia je najšrirsou kultúrnou entitou, " píše je to ,kultúra vo velkom" ${ }^{8}$ Naproti tomu francúzsky filozof Paul Ricoeur striktne rozlišuje medzi civilizáciou a kultúrou: kým civilizácia má byt produktom racionality, kultúra má mat svoj pôvod v re-kreácii symboliky. ${ }^{9}$ Akokolvek, zdá sa, že „civilizácia i kultúra sa vztahujú k celkovému spôsobu

$4 \quad$ Ibid., s. 14.

5 Ibid., s. $15-16$.

6 Ibid., s. 15.

$7 \quad$ Ibid., s. 34.

8 Ibid., s. 33.

9 Ricoeur 1993, s. $148-155$. 
života toho či onoho národa ${ }^{\text {"10 }}$ a definujú sa spoločnými objektívnymi prvkami, ako sú jazyk, náboženstvo, dejiny, zvyky či inštitúcie. ${ }^{11}$ Pritom základným civilizačným zdrojom a „blavným faktorom, charakterizujúcim civilizácie “12, ostáva náboženstvo. „Velké náboženstvá sú základy, na ktorých spocìvajú velké civilizácie, "13 tvrdí v uvedenom zmysle anglický historik Christopher Dawson. „Kultúra krajin sveta je formovaná predoršetkým náboženským myslením a konanim jej obyvateloov, "14 dodáva slovenská teologička a religionistka Monika Zaviš. Historickým faktom je, že štyri z piatich svetových náboženstiev založili civilizácie - krestanstvo, islam, hinduizmus a čínske, resp. japonské národné náboženstvá (konfucianizmus, taoizmus, šintoizmus). ${ }^{15}$

Svet po studenej vojne je multikultúrnym svetom diverzifikovaným do šiestich, resp. siedmich hlavných civilizácií: čínskej, japonskej, hinduistickej, islamskej, západnej, latinsko-americkej, prípadne africkej. ${ }^{16} \mathrm{~V}$ turbulentnej ére globalizácie sa "konflikt civilizácií" zdá byt" najväčšou hrozbou pre svetový mier a globálnu stabilitu, zatial' čo úsilie o mierové a humánne spolužitie sa ukazuje ako najväčšia výzva súčasnosti.

Samuel P. Huntington vidí záruku mierového spolužitia v medzinárodnom poriadku založenom na civilizáci-

10 Huntington 2001, s. 33.

11 Ibid., s. 35.

12 Ibid., s. 40.

13 Dawson „Dynamics of World History“ in Huntington 2001, s. 40.

14 Zaviš „Inkulturácia evanjelia v živote a diele Alberta Schweitzera“ in Gulán 2011, s. 109.

15 Výnimku predstavuje buddhizmus, ktorý bol v Číne a Japonsku asimilovaný.

16 Huntington 2001, s. 37 - 40. 
ách. ${ }^{17}$ Isto môžeme súhlasit s prominentným politológom $\mathrm{v}$ tom, že „budúcnost' mieru a civilizácie závisi od porozumenia a kooperácie medzi politickými, duchoonými a intelektuálnymi vodcami blavných svetových civilizáciı", ${ }^{18}$ ale nemôžeme súhlasit’ s tým, že závisí len od nich. Bolo by zjednodušené prenášat zodpovednost na "elity“ a ignorovat spôsob života jedincov a spoločnosti, ktorý určuje ludské konanie a správanie.

Predpokladáme preto, že základným faktorom globálneho spolužitia je morálny aspekt kultúry, ktorý sa vztahuje $k$ spôsobu života človeka, a tak vytvára rámcové predpoklady na mierové a humánne spolužitie na spoločenskej rovine. $V$ nasledujúcej kapitole budeme argumentovat' pre dialogický spôsob existencie (dialogický étos) ako taký spôsob života, ktorý vykazuje osobitný potenciál na mierové a humánne spolužitie.

\subsection{Kultúrny aspekt globálneho spolužitia: pluralistická paradigma postmoderny}

Ak niečo charakterizuje kultúru „planetárnej civilizácie", tak najskôr oslava plurality. Nejde pritom len o rešpekt $k$ pluralite možností, spojenej so slobodou volby, ako ho vyjadruje heslo popkultúry freedom of choice; nejde ani tak o uznanie mnohosti $\mathrm{v}$ jej spektakulárnej mnohotvárnosti ide najmä o oslavu mnohost $i$ a je to práve táto oslava mno-

17 Ibid., s. 393.

18 Ibid., s. 393. 
hosti, čo, ako sa zdá, stojí v pozadí postmoderného kultúrneho pohybu, ktorý je vlastný „planetárnej civilizácii“.

Pluralistická paradigma patrí k samotnému „genotypu“ postmoderny. Ked' postmoderna ohlásila koniec univerza moderny, a s ním aj koniec jednotného svetového názoru, ked' zavrhla racionalistickú ambíciu na všeobsiahlu teóriu, jedným dychom vyhlásila „nové univerzum“, predstavované mnohostou výkladových teórií. „Postmoderná éra sa zrodila zo straty modernej predstavy univerza,${ }^{19}$ píše Stanley J. Grenz, smerodajný americký interpretátor postmodernizmu, a namiesto toho ponúkla pluralitu parciálnych výkladov partikulárnych fragmentov mnohorako podmienenej skutočnosti. „Svet“ sa pred zrakom postmoderného človeka rozpadol na tisíce úlomkov.

Radikálnej pluralite postmoderny chýba jednotiaci motív, ak zaň nepovažujeme oslavu plurality ako základného „životného pocitu“. „Rozmanité a navzájom si odporujúce proky postmoderny nespája v jeden celok žiadne spoločné ohnisko,"20 sumarizuje svoje pozorovania Stanley Grenz. Usporiadanost' je "prežitok", kým neusporiadanost' sa Radimovi Paloušovi javí ako základný znak postmoderny. ${ }^{21}$ Bezbrehá pluralita hodnôt, ideí a foriem bez jednotiaceho ukotvenia, robí z postmoderny eklektickú zmes na spôsob koláže, ktorej je cudzia každá slohotvorná ambícia. Eklektický charakter postmoderny názorne ilustruje videoklip. Palouš ho považuje za najadekvátnejší výrazový prostriedok postmodernej doby, ${ }^{22}$ pretože mieša rozmanité výra-

\footnotetext{
19 Grenz 1997, s. 55.

20 Ibid., s. 27.

21 Palouš 1993, s. 12.

22 Ibid., s. 12.
} 
zové prostriedky a ignoruje štruktúru ustáleného slohu, hoci, paradoxne, napokon akýsi „sloh“ zakladá (videoéra). Ked' interpretuje život ako hru a slobodu ako svojvôlu (ktorá však nie je len anarchiou, ale tiež reakciou na kanonizovanú usporiadanost' slohových foriem - technokratický systém moderny), postmodernizmus znova objavuje rozmanitost' ako hodnotu.

$\mathrm{V}$ generačnej výmene rolí univerzalistickú interpretáciu skutočnosti nahradila interpretácia konštruktivistická. Konštruktivistická paradigma sa stala smerodajným intelektuálnym výkladom postmodernizmu. Konštruktivisti zdôrazňujú sprostredkovanú povahu l'udskej skúsenosti a akcentujú úlohu jazyka $\mathrm{v}$ procese porozumenia sveta, ktorý viac nie je daný, ale mnohonásobne podmienený. Význam sa utvára - konštruuje, nie odhaluje.

Pluralistická paradigma postmodernej kultúry nanovo problematizuje základnú etickú otázku morálneho zdôvodnenia. $\mathrm{V}$ postmodernom kontexte treba nanovo premysliet', prečo interiorizovat' hodnoty mravnej povahy, predovšetkým tie, ktoré sa vzt’abujú k spôsobu životajedinca a spoločenstva, a teda, konzekventne, $k$ medziludskému spolužitiu.

\subsection{Náboženský aspekt globálneho spolužitia: postsekulárna spoločnost’}

Náboženstvo je integrálnou súčastou sociálnej reality a zrejme tomu ani nikdy nebolo inak. Pre svoju trvalú prítomnost' v dejinách sa preto považuje za „antropologickú konštantu“. Náboženské prejavy pritom majú d’aleko od 
akejkolvek uniformity, zatial' čo v pozadí plurality náboženských javov treba hladat pre náboženstvo konštitutívnu skuisenost posvätna (lat. sacrum, numinosum). Do vztahu $\mathrm{k}$ tomuto tajomstvu, ktoré vzbudzuje úžas a bázeñ (Rudolf Otto), potom fenomenológovia náboženstva situujú pôvod náboženskej a spirituálnej vitality.

Osvietenské proroctvá o úpadku či dokonca zániku náboženstva - prinajmenšom jeho verejných prejavov a vplyvu - s pokrokom modernity, najmä s rozvojom vedy a techniky, formulované $\mathrm{v}$ sekularizačných teóriách novoveku, sa nenaplnili. Svet náboženstiev však v zmenených socio-kultúrnych podmienkach prechádza premenami. $\mathrm{V}$ protiklade $\mathrm{k}$ sekularizačným teóriám konkurenčná postsekularizačná téza charakterizuje sekularizáciu ako „dočasný odklon od určitého typu religiozity", ktorý je súčasne kompenzovaný nárastom záujmu o iný typ religiozity. ${ }^{23}$

Novodobé metamorfózy religiozity možno ilustrovat' na príklade nástupnických štátov Česko-slovenskej federácie. Kým v Českej republike modernita viedla k empiricky meratelnému úpadku tradičnej religiozity a jej nahradeniu alternatívnymi formami religiozity $\mathrm{v}$ podobe nových náboženských hnutí s rozličnými stupňami inštitucionalizácie, na Slovensku si tradičná religiozita v podobe etablovaných cirkví a náboženských spoločností nadalej uchováva svoje dominantné postavenie a alternatívne formy religiozity sa vo verejnom priestore presadzujú tažšie. $\mathrm{S}$ náboženstvami neeurópskeho pôvodu sa $\mathrm{v}$ oboch krajinách stretávame zväšša $\mathrm{v}$ podobe nových náboženských hnutí, ktoré z pôvodných tradícií nejakým spôsobom vychádzajú, ale pôsobia exteritoriálne mimo geografickej

23 Nešpor 2020, s. 12. 
a kultúrnej oblasti svojho pôvodného rozšírenia. $V$ tomto zmysle je napríklad buddhizmus na Slovensku a v Česku prítomný v podobe nových náboženských hnutí, ako sú Kwan Um Zen alebo Karma Kagjü. ${ }^{24}$

Český sociológ Zdeněk Nešpor konštatuje, že v oboch krajinách došlo po páde komunistického režimu a zrušení štátneho dozoru nad cirkvami v priebehu 90. rokov k rýchlej organizačnej konsolidácii tradičných náboženských inštitúcii. ${ }^{25}$ "Cirkvi, predovšetkým tie etablované, tak trualo ostávajú spoločensky významnými organizáciami a aktérmi verejnébo diania. “26 Ale pri obnove náboženského života etablované cirkvi nedokázali, resp. nechceli zmenit' modus svojej prevádzky, domnieva sa český sociológ. ${ }^{27}$ „V českých krajinách zostali uzatvorenév, náboženskom gete;, na Slovensku sa to týka menšich etablovaných cirkvi, zatial' co najuäčsia Rimskokatolicka cirkev vsadila na tradicionalistické spojenectvo so štátnymi orgánmi a využiva postavenie neoficiálnej (polo)štátnej cirkvi. “28

Pokles záujmu o inštitucionalizovanú cirkevnú religiozitu, ktorý, ako ukazuje Zdeněk Nešpor, prebieha v oboch krajinách v odlišnej miere, bol do istej miery kompenzovaný rastom záujmu o personalizované formy religiozity $v$ podobe spirituality. Trend nárastu dopytu po spiritualite, ako cirkevnej, tak aj necirkevnej s viaczdrojovým sýtením, je v súčasnosti zjavný.

24 Podoby novej religiozity na Slovensku mapujú dve vydania odbornej monografie Duchovná scéna na Slovensku (Macháčková, Dojčár 2001, 2002).

25 Nešpor 2020, s. 88.

26 Ibid., s. 47.

27 Ibid., s. 105.

28 Ibid., s. 105. 
Pre postsekulárnu spoločnosṫ západného typu je charakteristická progresívna kultúrna a náboženská diverzita. Kultúrnym rámcom tejto diverzity je „trh ideí“, kde vstupujú do vzájomného kontaktu a volnej sútaže trhového typu jednotlivé „ponuky zmyslu“ ako v náboženských i pseudonáboženských podobách, tak aj v spirituálnych i pseudospirituálnych formách. Tradičné etablované náboženstvá sa tu stretávajú s netradičnými náboženstvami (nové náboženské hnutia) a novými či staronovými duchovnými prúdmi ako rovný s rovným. Sú to práve nové náboženské hnutia, ktoré sa postupne stali smerodajným činitelom náboženského diania od druhej polovice 20. storočia. V situácii, ked',štát už dávno nemá monopol na oblast politiky a cirkvi, už dávno nemajú monopol na oblast' náboženstva a'29, ako upozorňuje Tomáš Halík, oslabuje postavenie národných štátov a spolu s klasickými politickými inštitúciami upadá aj význam cirkevných inštitúcií. Ak je „politický život súčasnej občianskej spoločnosti nesený viac dynamikou rôznych nových sociálnych hnutí a obcianskych iniciativ“, tak „dynamiku náboženského života dnes nesú blavne nové náboženské bnutia, "30 tvrdí Tomáš Halík.

Nové náboženské bnutia, teda „doteraz neetablované náboženské spoločenstvă", ktoré „vznikajú na základe náboženskej idey, ktorá je v určitej spoločnosti považovaná za novu ", ${ }^{31}$ predstavujú ,prirodzený dôsledok úsilia nájst' relevantné odpovede na otázky ludskej existencie“.32 Ako „výraz inovácie

\footnotetext{
29 Halík 2002, s. 194.

30 Ibid., s. 196.

31 Vojtíšek „Výzvy, specifika a možnosti dialogu se stoupenci nových náboženských hnuti ve svètle díla W. C. Smithe" in Floss, Hošek, Stampach, Vojtíšek 2008, s. 130 - 131.

32 Ibid., s. 131.
} 
duchovnébo života“"33 pritahujú záujem tých, ktorých neuspokojujú tradičné ponuky zmyslu tak, ako ich ponúkajú etablované náboženské inštitúcie. V prvom prípade sociológovia hovoria o „hladajúcich“ (angl. seekers), v druhom prípade o „zabývaných“ (angl. dwellers).

Od svojich počiatkov sa nové náboženské hnutia, inými slovami nová netradičná či alternatívna religiozita vyskytujú v bohato diferencovanej, temer neprehladnej podobe. Náboženská diferenciácia pokračuje dalej ako výraz hladania nových foriem duchovného a náboženského života, ktoré by lepšie zodpovedali novým potrebám a zmeneným životným podmienkam $v$ súčasnosti. Náboženská scéna sa triešti do pestrej mozaiky duchovných prúdov a smerov i siekt a kultov, ktoré sa delia o svoj životný priestor s tradičnými náboženskými formami a inštitúciami. Ale ani historicky staršie podoby náboženského života nie sú imúnne voči diferenciácii, aj oni môžu prechádzat' reformou a obnovou.

Hoci niektoré $\mathrm{z}$ inovácií náboženského života nadobúdajú sociálno-patologický charakter v podobe náboženského sektárstva, paušálne stotožnenie novej religiozity s fenoménom náboženského sektárstva nie je korektné. Sektárska mentalita prechádza naprieč celým náboženským spektrom a nie je obmedzená na inovácie náboženského života v podobe nových náboženských hnutí.

Sociológom a religionistom sa náboženská sekta môže javit' ako „náboženská spoločnost's totalitnými tendencia$m i$ “ ${ }^{34}$ Nehrá pritom rolu, akého je veku alebo pôvodu. ${ }^{35}$ Omnoho dôležitejšie sú znaky, ktoré takéto spoločenstvá

\footnotetext{
33 Ibid., s. 131.

34 Štampach 1998 in Rozmer 2, s. 7.

35 Stampach 1998, s. $164-165$.
} 
vykazujú. ${ }^{36} \check{C}_{i}$ je to autoritatívne vedenie, fundamentalizmus, uzavretost' a selekcia informácii, ${ }^{37}$ alebo kult osobnosti, exkluzivita, štruktúry vyznačujúce sa závislostou a konfiktnostou, ${ }^{38} \mathrm{v}$ sektách vždy dochádza $\mathrm{k}$ zneuživaniu. Je to predovšetkým náboženskost', teda vedomie a postoj závislosti od transcendentnej skutočnosti, čo sa v sektách stáva predmetom zneužitia.

Ani termíny sekta a kult sa významovo nekryjú. Na rozdiel od kultu, sekta v sociologickom zmysle vzniká ako prejav herézy, tzn. oddelenia, odštiepenia či odtrhnutia od väčšej a historicky staršej náboženskej skupiny, bez úmyslu zaviest' nové náboženstvo. ${ }^{39}$

Záujmom demokratickej a pluralitnej spoločnosti je pokojná denominalizácia nových náboženských hnutí a nekonfliktné spolužitie väčšinovej spoločnosti s nimi. Proti základnému celospoločenskému záujmu o pokojnú denominalizáciu a nekonfliktné spolužitie stojí krátkodobý záujem niektorých médií a občianskych iniciatív upútat pozornost nadviazaním na negatívne stereotypy vo vztahu $\mathrm{k}$ inováciám náboženského života. „Úlohou úradov, médií a obcianskych iniciativ, ktoré sa spolupodielajú na vytvárani postojor spoločnosti, teda je," ako upozorňuje Zdeněk Vojtíšek, "predist' hyperkritickému stavu morálnej paniky, pri ktorom spoločenský priestor ovládne, hoci neoprávnene, ale predsa len jednostranné stanovisko kritikov bnutia." "40

\footnotetext{
36 Vojtíšek 1998, s. 19.

37 Štampach 1998, s. 165 - 168.

38 Hummel „Sekty, nová náboženská hnuti? Kobjasnèni pojmů a obsahü in Sekty z pobledu cirkvi v Evropè 1998, s. 41.

39 Lužný 1997, s. 121.

40 Vojtíšek „Výzvy, specifika a možnosti dialogu se stoupenci nových náboženských hnuti ve svétle dila W. C. Smithe“ in Floss, Hošek, Štampach,
} 
Pokojná denominalizácia alternatívnej religiozity do celku religiozity určitej spoločnosti predpokladá kultiváciu morálneho aspektu kultúry danej spoločnosti, ktorý sa vztahuje na spôsob života človeka, a tak vytvára rámcové predpoklady pre nekonfliktné medziludské spolužitie. Tradičnými nositelmi morálky sú náboženstvá. Sú to práve náboženstvá, ktoré naprieč dejinami nesú posolstvo o hodnotovo ukotvenom spôsobe života a toto posolstvo zdôvodñujú odkazom na rôzne poňatú transcendenciu, ktorá sa rozličnými spôsobmi manifestuje $v$ imanencii.

\subsection{Antropologický aspekt globálneho spolužitia: alterita \& identita}

Vitálne medzikultúrne a medzináboženské interakcie v súčasnom mnohorako prepojenom svete so sebou prinášajú celý rad existenciálnych a socio-kultúrnych výziev. Kontakt s odlišnostou či inakostou (alterita, z lat. alter, „iný") sa môže stat podnetom pre názorovú konfrontáciu, ktorá má potenciál prerást do afektívne sýteného konfliktu a prejavovat' sa $\mathrm{v}$ duševnom prežívaní zúčastnených osôb ako kriza.

Pozorovanie ukazuje, že kontakt s alteritou môže vyvolat psychické reakcie kvalitatívne odlišného typu. V jednom prípade ide o xenofóbnu odpoved' na podnet, ktorý ako neznámy budí u zainteresovaných osôb obavy. $\mathrm{V}$ druhom prípade podnet, ktorý je prvoplánovo percipovaný

Vojtíšek 2008, s. 139. 
ako ohrozujúci, môže katalyzovat procesy kritickej reflexie, prípadne transformácie osobnej identity v zmysle jej reštrukturalizácie. Kým v prvom prípade sa psychická energia, blokovaná „šokom“ z kontaktu s alteritou uvolňuje $\mathrm{v}$ prejavoch animozity, ktoré predstavujú regresínny vývinový pohyb, $\mathrm{v}$ druhom prípade smeruje do procesov transformácie, resp. reštrukturalizácie osobnej identity, ktoré naopak predstavujú progresíny vývinovú pohyb.

Predpokladáme teda, že krizová situácia, ktorá vzniká v reakcii na odlišné kultúrne, resp. náboženské prejavy a formy, sa môže, medzi iným, manifestovat v xenofóbii. Xenofóbia má ex definitione pôvod v skúsenosti toho, čo je nám cudzie, a teda neznáme (gr. xenos), a preto v nás vyvoláva obavy (gr.fobia). Nech je jej podoba akákolvek, xenofóbia môže súvisiet's vedomím ohrozenia vlastnej identity, nakol'ko ,odlišnost', inakost' a cudzost'si nemôžeme jednoducho privlastnit" ${ }^{41}$ a zaradit do vlastného poriadku sveta. ${ }^{42}$

Špecifickú formu xenofóbie predstavuje religiofóbia., $R e-$ ligiofóbiou rozumieme také formy xenofóbie, ktoré sa nejakým spôsobom vztahujú ku náboženstvu (napr. antijudaizmus, islamofóbia, militantný ateizmus a pod.) ${ }^{{ }^{* 43} \mathrm{~V}}$ uvedenom zmysle religiofóbia predstavuje podmnožinu xenofóbie.

Pôvod xenofóbie sa niekedy vysvetluje cez výkladový vzorec: stereotypy + predsudky $=$ xenofóbia. Zdá sa však, že táto interpretácia xenologického problému nemôže uspokojivo vysvetlit jeho povahu, ani ponúknut východisko pre jeho riešenie. Pochopitelne, význam stereotypov a predsudkov vo vztahu k xenofóbii netreba ani marginalizovat'. Stereo-

\footnotetext{
41 Mráz 1999, s. 96.

42 Poláková 1998, s. 471.

43 Dojčár „Religiofóbia v epoche konfliktu civilizáciı“ in Dojčár 2016, s. 10.
} 
typy a predsudky, ako relatívne stabilné „predstavy, názory a postoje "vo vztahu $\mathrm{k}$ iným, ${ }^{44}$ treba považovat za významné faktory správania zvláśt', ak sú spojené $s$ animozitou. ${ }^{45}$

Domnievame sa ale, že pre porozumenie xenologického problému je dôležitejšia súvislost' medzi xenofóbnou percepciou alterity a sebaporozumenim, teda individuálnou identitou jedinca a sociálnou identitou spoločenstva, vrátane jej náboženského aspektu (náboženská identita). Práve náboženská identita nesie $\mathrm{v}$ sebe mohutnú dynamiku, napájanú z náboženských zdrojov, medzi ktoré patria systémy presvedčení, hodnôt, symbolov, rovnako ako náboženské rituály a úkony.

Individuálna identita, čiže spôsob, akým jedinec rozumie sám sebe, tak isto ako sociálna identita, čiže spôsob sebaporozumenia v sociálnom kontexte, sú založené na rovnakom mechanizme identifikácie s určitými osobnostnými a socio-kultúrnymi hodnotami, vlastnostami, schopnostami a pod. Pod pojmom identita teda rozumieme dynamický komplex identifikácii s objektivizovatelnými fenoménmi psychickej, somatickej, kultúrnej, náboženskej, sociálnej a hodnotovej povahy.

Predpokladáme súvislost' medzi xenofóbiou a individuálnou, resp. sociálnou identitou v tom zmysle, že v obrozeni ci spochybneni tohto komplexu identifikáciu, inymi slovami-v krize identity navrbujeme bladat'korene každej formy xenofóbie.

Dalej predpokladáme, že medzikultúrne a medzináboženské interakcie, spojené s xenofóbnou percepciou alterity, môžu katalyzovat procesy kritickej reflexie vlastnej

44 Průcha 2004, s. 67.

45 Ibid., s. 173. 
identity, teda procesy reflexie nášho vlastného sebaporozumenia, čiže obrazu o tom, kto sme, či konceptu, ktorý si o sebe vytvárame počas nášho života. Je to tento obraz o sebe, s ktorým sa identifikujeme v procese konštruovania našej osobnej identity, a je to ten istý obraz, ktorý považujeme za ohrozený v konfrontácii s alteritou. Xenofóbia takto nemusí byt' jedinou reakciou na kultúrnu či náboženskú inakost' - krízové situácie môžu tiež katalyzovat’ kritickú reflexiu vlastnej identity a následne procesy jej reštrukturalizácie, či transformácie. Zatial čo xenofóbia sa javí ako „reaktívna“ odpoved' na krízovú situáciu a z morálneho hladiska zodpovedá pojmu „čin človeka“ (lat. actus hominis), kritická reflexia na úrovni vlastnej identity sa ukazuje ako autenticky ludská odpoved' na životnú výzvu a z morálneho hladiska zodpovedá pojmu „ludský čin“"(lat. actus humanus).

Životné poslanie človeka byt' človekom a konat' ludsky ( humanita, z lat. humanitas, „ludskost") nachádza svoj osobitný výraz v dialogickom spôsobe existencie (dialogický étos) ako špecifickej modalite dialógu, ktorý si predstavíme v nasledujúcej kapitole. 



\section{Dialogický étos}

Pojmy dialóg a komunikácia sa často zamieňajú a považujú za synonymá. Dialóg sa však v skutočnosti od komunikácie líši hĺbkou a bohatstvom svojich významov. Rozlišujeme tu tri významové roviny tohto pojmu: dialóg ako forma komunikácie, dialóg ako interpersonálna udalost', a napokon dialóg ako spôsob existencie (dialogický étos). Prístupovým pojmom na ich interpretáciu nám bude pojem komunikácia.

\subsection{Komunikácia}

Človek je súčasne tvorcom kultúry (lat. bomo faber, homo creans) i spoločenskou bytostou (gr. zóon politikon). Ako homo creans používa znaky a vytvára štruktúry, aby vyjadril sám seba. Ako zóon politikon vstupuje do interpersonálnych vztahov a vytvára sociálne väzby, ktoré patria $\mathrm{k}$ jeho plne ludskej existencii.

Znaky a štruktúry sú správy. Tie osoba explicitne alebo implicitne adresuje iným osobám či spoločenstvám osôb.

Človek teda svoje správy komunikuje. Komunikácia je výmena správ medzi osobami prostrednictvom média jazyka, obrazu ci zvuku. Jazyk je systém znakov, resp. kódov, ktorý slúži na transfer správ.

Z interpersonálnej povahy komunikácie vyplýva, že komunikačný proces má dve štrukturálne zložky - odo- 
sielatela a prijímatela správ. Komunikácia, ako zdielanie zvnútorneného a socio-kultúrne podmieneného porozumenia sveta $\mathrm{v}$ podobe správ, je manifestáciou osoby ad extra. Adekvátna interpretácia komunikácie preto predpokladá hermeneutiku, ako teóriu porozumenia, a antropológiu, ako teóriu o človeku - nevystačí si len s lingvistikou, semiotikou, či logikou, hoci ich prínos pre porozumenie komunikačných procesov je nespochybnitelný.

\subsection{Dialóg ako forma komunikácie}

Dialóg vo svojom bazálnom zmysle je jednou $\mathrm{z}$ foriem komunikácie. To, čo ho odlišuje od iných foriem komunikácie, je predovšetkým jeho personálny charakter. Obsahom dialógu totiž nikdy nie je samotná správa ako „plochá" informácia; súčasne s ňou je to aj personálny kontext správy. Ten zahŕña porozumenie predmetnej veci v jej relácii ku poznávajúcemu subjektu i reflexiu tejto navýsost individuálnej relácie. Autentický dialóg preto začína až uznaním onej relatívnej povahy vlastného pohladu, ktorá je súčasne uznaním plurality pohladov - nebol, nie je a nebude jeden a výlučný pohlad na skutočnost'.

$\mathrm{V}$ dialógu potom dochádza $\mathrm{k}$ oceňujúcej konfrontácii čiastkových pohladov na skutočnost', založenej na predpoklade, že táto konfrontácia môže viest' úplnejšiemu pohladu - k plnšiemu porozumeniu skutočnosti. ${ }^{46}$ Ked' otvára priestor slobodnej výmeny a tvorivého hladania porozumenia, dialóg legitimizuje autonómiu drubého ako

46 Štampach 1993, s. 13. 
svojbytného a žiaduceho partnera onej interpersonálnej výmeny a odkrývania porozumenia. Dialóg je takto zo svojej povahy afirmáciou druhého ako druhého - je potvrdením autonómie a neodcudzitelnej vnútornej hodnoty osoby dôstojnosti človeka.

\subsection{Dialóg ako interpersonálna udalost’}

Dialóg ako stretnutie autonómnych osôb založené na princípoch vztahovosti („vzájomnost", Martin Buber) a $f$ nality predstavuje personálny rozmer komunikácie - je interpersonálnou udalostou.

Finalita zameraná na ciel" odlišuje dialóg od konverzácie, ktorá môže byt samoúčelná alebo bezobsažná, zatial' čo dialóg bez ciela nejestvuje. ${ }^{47}$ Druhým základným identifikačným znakom tejto modality dialógu je, že ide o stretnutie (Jolana Poláková), vzájomnost'(Martin Buber), vztảb: účastníci dialogického stretnutia sa stávajú partner$\mathrm{mi} \mathrm{v}$ dialógu, vo svojej osobnej autonómii slobodne vstupujú do vzájomného vztáhu (vzájomnost'), aby vytvorili spoločenstvo osôb (lat. communio personarum) stmelené spoločným cielom (finalita).

Súčasne platí, ako upozorňuje český teológ a religionista Pavel Hošek, že „[d]ialogické stretnutie s Drubým nemožno vopred naplánovat,' ${ }^{48}$ jeho výsledky nemožno anticipovat', pretože „neviem, kto [pozn. druhý] je, neviem to

47 Poláková 1998, s. 465 - 466.

48 Hošek 2005, s. 157. 
vopred ". ${ }^{49}$ Inakost' druhého sa odhaluje až v dialogickom spoločenstve, $\mathrm{v}$ obojstrannom prijatí a uznaní, založenom na ,etike pohostinnosti “. ${ }^{50}$

Interpersonálny rozmer dialógu s jeho akcentom na prioritu vztabu a autonómiu exteriority vystupuje do popredia vo fllozofi dialogu. ${ }^{51}$ Pre Martina Bubera je klúčom porozumenia druhého práve vztah ako stretnutie autonómnych osôb - „Ja a Ty“. ${ }^{2}$ Porozumiet' druhého možno iba v priestore vztahu, pretože „Ty“ uniká zvecneniu. ${ }^{53}$ "Vztả h je vzájomnost ${ }^{\prime \prime 54}$ hovorí Buber, ktorou sa subjekty vztahu otvárajú pre intersubjektívne porozumenie.

$\mathrm{Na}$ rozdiel od sokratovsko-platónskeho typu dialógu (maieutika, gr. „metóda pôrodnej baby“, resp. , pôrodnícka metóda"), základom buberovského typu dialógu je preto vzájomnost.' Kým Sokratés kladie dôraz na dialektický rozmer dialógu ${ }^{55}$ ked' predpokladá, že poznanie je latentne prítomné v človeku a treba ho len „priviest' na svet“, Martin Buber akcentuje (inter)personálny rozmer dialógu, ked' poukazuje na prioritu vztahu s partnerom v dialógu (vzájomnost) a jeho autonómiu ako svojbytnej osoby (exteriorita).

Buber považuje vztah za hodnotu osebe. „Vieme, že melódia nie je len niečím, co sa skladá z tónov," píše, „verš len niečím, co sa skladá zo slor, a ozdobný stlp len niečim, co sa skladá z linii. Vieme, že to visetko musime takpovediac

\footnotetext{
49 Ibid., s. 158.

50 Ibid., s. 162.

51 Buber 2001, s. 144.

52 Buber 2005, s. 38 - 39.

53 Ibid., s. $39-42$.

54 Ibid., s. 48.

55 Hošek 2005, s. 149.
} 
roztrhat' a rozšklbat', ak máme premenit jednotu na mnohost'. Rovnako je tomu sčlovekom, ktorému hovorím ty. Môžem sa zamerat' na to, aby som poznal farbu jeho vlasov alebo farbu jeho reči či farbu jeho dobroty, a musim si tak počinat' znova a znova; ale on pritom prestáva byt'Ty. " ${ }^{6}$

Je to práve jeho vztahový rozmer, ktorý prepožičiava dialógu privilegované postavenie $\mathrm{v}$ súčasnom multicivilizačnom svete. Vo svojom interpersonálnom rozmere sa dialóg ponúka ako nástroj facilitácie xenofóbie, ked’obnovuje komunikáciu tam, kde z nedostatku vzájomnosti stroskotala a otvára stretnutie, ktoré umožňuje prijat inakost' druhého. ${ }^{57}$ "Znepokojivá skúsenost' cudzieho" 58 sa v dialógu stáva výzvou otvorenia sa voči inakosti druhého, je príležitostou $\mathrm{k}$ stretnutiu a začiatkom osobného vztahu, ktorý môže vyústit do vzájomného porozumenia, dorozumenia a spolužitia.

\subsection{Dialogický spôsob existencie}

Dialóg vo svojej dimenzii interpersonálnej udalosti môže vyústit do dialogického spôsobu existencie, ak sa stane spôsobom života založenom na morálnom postoji, ktorý vychádza z dialogického princípu vztahovosti ( $v z a^{-}$ jomnost). Interpersonálny rozmer dialógu takto spolutvorí, inšpiruje a rozvíja dialogický étos - „základný morálny postoj jednotlivca, resp. spolocenstva, formovany principom

\footnotetext{
56 Buber 2005, s. 42.

57 Dojčár 2010, s. 15.

58 Waldenfels 1998.
} 
vztahovosti". ${ }^{59}$ Vice versa, dialogický étos sa manifestuje vo svojich dvoch základných prejavoch - ako interpersonálna udalost’ a ako personálna forma komunikácie.

Dialogický étos existenciálnym spôsobom potvrdzuje autonómiu človeka ako nepodmienenú a jeho vnútornú hodnotu ako neodcudzitel'nú, a súčasne sa ponúka ako personálny prístup k riešeniu xenologického problému, ked' proti neprijatiu druhého, stavia jeho nepodmienené prijatie. V dialogickej vztahovosti, ktorá je príklonom k druhému ako druhému, sa rodí lepšie porozumenie a ocenenie iného ako osoby v jej svojbytnosti a dôstojnosti. Ako taký dialogický spôsob existencie (dialogický étos) sa tiež ponúka ako prvotná podoba oblasovania, predchádzajúca všetkým formám misijnej aktivity, v ktorých sa rozličným spôsobom uplatňuje ludská racionalita, afektivita a voluntarita. Je to prvotná forma misie vo svojej primordiálnej - predpojmovej a predverbálnej podobe - založená na „bytí človekom“, ktoré prijíma, uznáva a oceňuje bytie iného človeka ako Bohom chcené a stvorené. Priestor afirmácie autonómie a dôstojnosti druhého je priestorom stretnutia, je vztahovostou, odkazujúcou na krestanský model každého spoločenstva - na dynamiku vnútorného života trojjediného Boha.

\subsection{Dialogický model medzináboženských vztahov}

Dialogický model medzináboženských vztahov sa objavuje na scéne dejín v 20. storočí. Aj predtým boli síce

59 Dojčár 2012, s. 65. 
v histórii známe momenty tolerancie, porozumenia a spolupráce, predchádzajúce dejinné obdobia však mali iné akcenty v náboženskej oblasti. Až predchádzajúce storočie vytvorilo podmienky pre vznik takého modelu medzináboženských vztahov, ktorý je založený na dialógu.

Ak dialóg vo všeobecnosti predpokladá osobné stretnutie autonómnych a vo svojej nepodmienenej dôstojnosti rovnocenných osôb - jeho východiskom je neredukovatelná a nedisponovatel'ná inakost' druhého - tak pre medzináboženský dialóg, čoby špecifický typ dialógu, to platí v nezmenenej podobe: „Dialóg nemá byt' konfrontáciou náboženských systémov a tradicii, ale skôr stretnutím veriacich rozličných náboženstiev, "60 zdôrazňuje slovenský misiológ Ladislav Bučko.

Spoločenský a politický vývoj v našich časoch ukazuje, akú významnú úlohu zohráva dialóg v pluralitnej a demokratickej spoločnosti západného typu. Predchádzajúce storočie prinieslo nové ocenenie dialogického myslenia medzi iným vo filozofii (napr. flozofia dialógu), v edukácii (napr. tvorivo bumanistické vzdelávanie), či v systematickej a praktickej teológii (napr. teológia náboženstiev, ekumenickýa medzináboženskýdialóg). K dialógu sa oficiálne prihlásila Katolícka cirkev, najväčšia náboženská inštitúcia sveta, ked’ výzvu k dialógu Cirkvi adresoval Druhý vatikánsky koncil (1962 - 1965). V cirkevnom Magistériu dialóg rezonuje nielen ako forma komunikácie, ale aj ako nástroj otvorenia sa, zdnešnenia (tal. aggiornamento) Katolíckej cirkvi, ktoré ohlásil Druhý vatikánsky koncil. Otvorenie sa Katolíckej cirkvi smerom dovnútra i navonok sa má, podla

60 Bučko 2003, s. 400. 
ostatného cirkevného snemu, uskutočňovat’ predovšetkým prostredníctvom dialógu. ${ }^{61}$

Na Druhom vatikánskom koncile Katolícka cirkev po prvý raz vo svojich dejinách doktrinálne záväzným spôsobom sformulovala a teologicky odôvodnila svoj postoj k mimokrestanským náboženstvám. V koncilovej deklarácii o vzt’ahu Cirkvi k nekrest’anským náboženstvám Nostra aetate z 28. októbra 1965 tak urobila príkladne dialogickým spôsobom:

"Katolicka cirkev nezavrbuje nič z toho, čo je v týchto náboženstvách pravdivé a sväté. S úprimnou úctou hl'adi na tie spôsoby konania a správania, na pravidlá a učenia, ktoré sa sice v mnohom liśia od toho, co ona sama zachováva a uči, no predsa sú nezriedka odbleskom tej Pravdy, ktorá osvecuje všetkých ludi. Cirkev však oblasuje a je povinná neprestajne oblasovat'Krista, ktorý je Cesta, Pravda a Život (Jn 14, 6), v ktorom ludia nachádzajú plnost' náboženského života a v ktorom Boh zmieril so sebou všetko.

Preto Cirkev porzbudzuje svojich synov a dcéry, aby $s$ múdrostou a láskou vydávali svedectvo o viere a krestanskom živote, nadviažuc dialóg a spoluprácu s vyznávačmi iných náboženstiev, a uznávali, chránili a zveladovali duchovné, mravné a spoločensko-kultúrne hodnoty, ktoré sa v nich nachádzajú."

Tromi jednoduchým a súčasne silnými slovami deklarácia charakterizuje postoj krestana k nekrestanským náboženstvám - uznat', chránit' a zveladovat'. Krestan má nielen rešpektovat či tolerovat hodnoty iných náboženských tradícií - a už vôbec nie ich popierat'-, ale naopak,

61 Lehman 1996, s. $2-3$.

62 Nostra aetate, čl. 2. 
má ich pozitívne a proaktívne oceňovat', ochraňovat' a rozvijat! Týmto spôsobom tiež vyznáva svoju vieru vo všemohúceho a všadeprítomného Boha, ked’ iniciatívne hladá a nachádza "stopy“ Božieho pôsobenia v stvorení „semená Slova“ a "lúce Pravdy“ patristickej teológie, pretože ostatný cirkevný snem potvrdzuje patristické učenie o univerzálnom pôsobení Božej milosti: Božia milost' je prítomná v stvorení ako "lúc Pravdy, ktorá osvecuje vošetkých ludi", 63 ako „semená Slova" a „bohatstvo, ktoré stedrý Boh rozdelil medzi národy“, ${ }^{64}$ ako dobro „zasiate v mysliach a srdciach ludı" a "v obradoch a zoykoch národov". 65

Oficiálny postoj Katolíckej cirkvi k nekrestanským náboženstvám je založený na pozitíunom hodnoteni nekrestanských náboženských tradicii. Cirkev $\mathrm{k}$ nim pristupuje „citlivo vzhladom na duchovné a ludské hodnoty, ktoré v sebe ukrývajü. ${ }^{66}$

Ocenenie je východiskom medzináboženského dialógu ako v koncilovom, tak aj pokoncilovom učení Katolíckej cirkvi. Dialóg „vychádza z blbokého rešpektu pred všetkým, co spôsobil v človeku Duch, ktorý veje kam chce," rozvíja koncilové učenie o dialógu pápež Ján Pavol II. vo svojej encyklike Redemptoris missio: „V ňom sa Cirkev usiluje objavit', semená Slova' a lúce pravdy', ktoré osvecujú vóetkých ludí, semená a lúce, ktoré sú pritomné v osobách a náboženských tradiciách ludstva. "67 Ako nositelia pozitívnych hodnôt a manifestácie Božej milosti „[i]né náboženstvá sú pre

\footnotetext{
$63 \quad$ Ibid., čl. 2.

64 Ad gentes, čl. 11.

65 Lumen gentium, čl. 17.

66 Dialóg a oblasovanie, čl. 11.

67 Ján Pavol II. 1997, čl. 56.
} 
Cirkev výzvou; podnecujú ju objavovat' a uznávat'znamenia pritomnosti Krista a pôsobenia Ducha“ ${ }^{68}$

Práve dialóg má, podla koncilového pápeža Pavla VI., pomôct' človeku objavit', „aké rozličné cesty vedú $k$ svetlu a môżu smerovat' $k$ tomu istému cielu. A ked'sa aj niekedy rozchádzajú, môžu sa navzájom zasa doplňovat' a pobádat' nás zrevidovat' obvykly postup myslenia, preblbit' naše výskumy a zdokonalit'spôsob vyjadrovania. Trpezlivé cvičenie sa v tejto dialektike myslenia bude mat'za následok, že aj v nábl'adoch iných nájdeme zrnká pravdy. " 69

Z uvedených dôvodov „Cirkev podporuje a podnecuje medzináboženský dialóg, nielen pokial'ide o jej dialóg s inými náboženskými tradíciami, ale aj ked'ide o vzájomny dialóg medzi týmito tradiciami. Toto je jeden zo spôsobor, ktorými naplña svoju úlohu ,byt' sviatostou, to jest znakom a nástrojom spoločenstva s Bohom a jednoty medzi lud'mi'(Lumen gentium 1)." "70

Verná svojmu dialogickému záväzku pokoncilová Katolícka cirkev kreuje inštitúcie, ktoré majú napomáhat’ medzináboženskému dialógu. $\mathrm{Na}$ centrálnej úrovni cirkevnej správy (dikastérie Rímskej kúrie) je to Pápežská rada pre medzináboženský dialóg, ako nástupnícky orgán Sekretariátu pre nekrestanov (1964 - 1988). Od roku 1966 vychádza Bulletin venovaný medzináboženskému dialógu a od roku 1978 sa živo rozvíja medzimníšsky dialóg, ktorého súčasným lídrom je Mnišsky medzináboženský dialóg (DIMMID) - komisia benediktínskej konfederácie implementujúca dialogické politiky pokoncilovej cirkvi a $P a ́-$ pežskej rady pre medzináboženský dialóg.

68 Ibid., čl. 56.

69 Pavol VI. 1968, čl. 85, s. 50.

70 Dialóg a oblasovanie, čl. 80. 
Koncilové aggiornamento bolo možno príliš optimistické, ale predsa len smerodajné. ${ }^{71}$ Katolíckym krestanom je dnes zrejmé, že „schopnost' a ochota viest dialóg je pre Cirkev i spoločnost životnou otázkou" ". ${ }^{72}$ "Cirkev musi nadviazat" dialóg so svetom, v ktorom žije, "73 deklaruje pápež Pavol VI. vo svojej encyklike Ecclesiam suam z roku 1964, pretože dialóg, „je v úmysloch Božičch ${ }^{74}$ Aby sa Cirkev stala „znamenim bratstva, ktoré umožňuje a preblbuje dialóg" tak, ako to od nej žiada pastorálna konštitúcia Druhého vatikánskeho koncilu Gaudium et spes o Cirkvi v súčasnom svete, ${ }^{75}$ je potom potrebné v samotnej Cirkvi prehlbovat vzájomnú úctu a jednotu pri rešpektovaní legitímnej rozmanitosti mienok. ${ }^{76}$

\subsection{Dialóg ako forma ohlasovania}

„Dvojitý záväzok“ Katolíckej cirkvi k dialógu a ohlasovaniu ${ }^{77}$ stavia katolíckych krestanov pred otázku: $A k o$ uviest' do súladu dialóg a oblasovanie, ked,' ako sa zdá, stoja vpriamom protiklade?

71 Konštitúcie Druhého vatikánskeho koncilu Lumen gentium, Gaudium et spes a Dei verbum predstavujú vieroučne záväznú teologickú reflexiu výzvy Jána XXIII. k aggiornamentu. Vyhlásenie o náboženskej slobode Dignitatis humanae a Dekrét o apoštoláte laikov zas reprezentujú najmarkantnejšie svedectvo koncilového obratu k otvorenosti.

72 Lehman 1996, s. 5.

73 Pavol VI. 1968, čl. 67, s. 43.

74 Ibid., čl. 72, s. 45.

75 Gaudium et spes, čl. 92.

76 Ibid., čl. 92.

77 Dialóg a oblasovanie, čl. 89. 
Do teologickej diskusie o vztahu medzi ohlasovaním (evanjelizácia, resp. misia) a dialógom (medzináboženský dialóg) prispejeme nasledujúcou tézou: fundamentálnou formou misie je dialogický spôsob existencie, a ponúkneme argument pre porozumenie dialógu, ako autonómnej formy ohlasovania v uvedenom zmysle založený na teologicko-antropologickej interpretácii človeka ako „obrazu Boha“.

Teologické premyslenie vztahu medzi dialógom a ohlasovaním je témou, ktorá nachádza odozvu vo vyjadreniach Učitelského úradu Cirkvi, v publikáciách teológov, aj v úvahách krestanov angažovaných v misijnej práci a v medzináboženskom dialógu. Tejto téme sa výslovne venuje dokument Magistéria Dialóg a oblasovvanie, ktorý 19. mája 1991 vydali dve dikastérie Rímskej kúrie - Pápežská rada pre medzináboženský dialóg a Kongregácia pre evanjelizáciu národov. Dokument bol zverejnený pri príležitosti 25 . výročia vyhlásenia Nostra aetate, prelomovej deklarácie Druhého vatikánskeho koncilu o vztahu Cirkvi k nekrestanským náboženstvám, a priamo nadväzuje na starší dokument Postoj Cirkvi $k$ stúpencom iných náboženstiev: úvahy a usmernenia týkajúce sa dialógu a poslania Cirkvi, ktorý v roku 1984 publikoval vtedajši Sekretariát pre nekrestanov. Oba uvedené dokumenty súhlasne predstavujú dialóg a ohlasovanie ako dve zložky jedného evanjelizačného poslania Cirkvi, pričom neskorší dokument Dialóg a oblasovanie tento vztah dalej teologicky rozpracováva vzhladom na možné pochybnosti čo sa týka zmyslu dialógu, ako aj ohlasovania, ${ }^{78}$ a súčasne ,podrobnejšse rozvija náuku o dialógu a jeho vztahu k oblasovaniu" obsiahnutú v encyklike Jána Pavla II. Redemptoris missio. ${ }^{79}$

78 Ibid., čl. 4c.

79 Ján Pavol II. 1997, čl. 55 - 57. Dialóg a oblasovanie, čl. 4c. 
V koncilovej deklarácii Nostra aetate zaznel „dvojitý záväzok" Cirkvi k medzináboženskému dialógu a ohlasovaniu Krista, ktorý je Cesta, Pravda a Život. ${ }^{80}$ Dokument Dialóg a oblasovanie potvrdzuje koncilové ocenenie dialógu, a súčasne aj záväzok Cirkvi ohlasovat Krista, a teda „privádzat ludi k jasnému poznaniu toho, čo Boh vykonal v Ježišovi Kristovi pre všetkých ludi, a pozýnat ich, aby sa stali Ježišovými učenikmi tým, že sa stanú členmi Cirkvi “.81

Dialóg a ohlasovanie dalej interpretuje ako dve komplementárne zložky evanjelizačnej misie: „Sú úzko späté, no nezamenitelnê", sú „oddelene" ${ }^{\text {"82 }} \mathrm{v}$ tom zmysle, že dialóg je „zameraný na oblasovanie“", 83 ale súčasne spojené, pretože oblasovanie sa má uskutočnovat formou dialógu. ${ }^{84}$

Téza o dialógu ako forme ohlasovania ponúka viacero možností interpretácie. $V$ najširšom zmysle môže odkazovat' na dialóg ako formu komunikácie, $\mathrm{v}$ užšom zmysle môže poukazovat' na vztahový rozmer dialógu ako interpersonálnej udalosti, ale rovnako dobre môže odkazovat' aj na dialogický spôsob existencie, ako je tomu v prípade našej premisy: fundamentálnou formou misie je dialogický spôsob existencie.

Prvotná forma misie založená na „bytí človekom“ a manifestujúca sa v dialogickej vztahovosti, ktorú tu nazývame dialogický spôsob existencie alebo dialogický étos, predpokladá porozumenie človeka ako nositela neodcu-

\footnotetext{
80 Nostra aetate, čl. 2.

81 Dialóg a oblasovanie, čl. 81.

82 Ibid., čl. 77.

83 Ibid., čl. 82.

84 „Ohlasovanie Ježiša Krista preto prebieha v evanjeliovom duchu dialógu." Ibid., čl. 77.
} 
dzitelnej vnútornej hodnoty - dôstojnosti, zakladajúcej jeho autonómiu.

Dôstojnost' človeka (lat. dignitatis humanae) je vnútorná hodnota, ktorú vlastní každý človek nepodmieneným spôsobom a ktorá ho robí účelom osebe. Takto, ako účel osebe, človek je autonómny - môže si klást mravný zákon - určovat spôsob svojho života (z gr. auto, „sám“, nomos, „zákon“). Jeho vnútorná hodnota nepochádza zo sociálnej interakcie ani zo spoločenského statusu, role, či z akejkolvek aktivity, ale zo samotného bytia človekom.

Biblická, židovsko-krestanská tradícia odvodzuje vnútornú hodnotu človeka zo stvorenia človeka ,na obraz Boha“ (lat. imago Dei) a "podla podoby Boha" (lat. similitudo Dei), ako o ňom vypovedajú dve biblické správy o stvorení človeka v jahvistickom $(\mathrm{Gn} 2,7)$ a kñazskom (Gn 1, 26 - 27) podaní.

V Novom zákone je „obrazom neviditelného Boha“ Kristus (Kol 1,15). Človek je „obrazom Boha“ lebo je stvorený "podla podoby Boha“, ktorou je Kristus. Preto Kristus, ako predobraz človeka, dáva človeku poznat', čo to vôbec znamená byt' človekom.

Pojem „Boží obraz“ (gr. eikón tou Theou) vyjadruje výnimočný charakter vztahu, ktorý spája človeka s jeho Stvoritel'om, odlišuje ho od mimoludskej skutočnosti a udeluje $\mathrm{mu}$ osobitnú vnútornú hodnotu - dôstojnost.' Takto neodcudzitelná vnútorná hodnota človeka, ako účelu osebe $\mathrm{v}$ euro-atlantickom civilizačnom priestore, odvodzuje svoj pôvod kultúrne určujúcim spôsobom $\mathrm{z}$ antropologickej paradigmy imago Dei.

Dôstojnost človeka nachádza svoj výraz v étose ludských práv, ktorý paradigmaticky charakterizuje civilizáciu západného typu. Všetci ludia sú si rovní a rovnost’ 
medzi lud'mi sa zakladá na ich ničím nepodmienenej autonómii a neodcudzitel'nej dôstojnosti a na právach, ktoré z nej vyplývajú.

Dôstojnost človeka si vyžaduje uznanie kategoricky, teda bezpodmienečne, čiže bez ohladu na úžitok, aký jednotlivec prináša alebo môže prinášat iným. Interkultúrne univerzálnym spôsobom ju garantuje zlaté pravidlo morálky: Čo nechceš, aby druhí robili tebe, nerob ani ty im! (negatívna formulácia Tob 4,15); Čo chceš, aby druhí robili tebe, rob aj ty im! (pozitívna formulácia Mt 7, 12; Lk 6, 31).

K afirmácii autonómie a dôstojnosti človeka v kontexte sociálnej interakcie dochádza predovšetkým v dialógu. Dialóg jedinečným spôsobom potvrdzuje autonómiu a vnútornú hodnotu partnera $\mathrm{v}$ dialógu oceňujúc jeho existenciu ako žiadúcu a obohacujúcu. Deje sa tak vo všetkých troch modalitách dialógu - v dialógu ako forme komunikácie, v dialógu ako interpersonálnej udalosti, a napokon v dialógu ako špecifickom existenciálnom postoji, ktorý tu označujeme výrazom dialogický spôsob existencie, resp. dialogický étos.

Potvrdenie autonómie a dôstojnosti človeka $\mathrm{v}$ medzináboženskom dialógu je zo strany krestana aktom jeho viery v stvorenie človeka „na Boží obraz“ - je uznaním človeka ako imago Dei-, a je tiež svedectvom o Kristovi, ktorý je „Božou podobou“ a prvotným modelom človeka. $\mathrm{V}$ tomto zmysle je dialogický spôsob existencie fundamentálnou formou ohlasovania. 


\subsection{Záver}

Katolícki krestania vyznávajú, že Cirkev je zárodkom a počiatkom Božieho králoustva na zemi. ${ }^{85}$ Pretože Cirkev už prijala plnost' zjavenia, ale neprijala ešte plnost' jeho porozumenia, je Cirkvou putujúcou ${ }^{86}$ - je Božím ludom, ktorý „smeruje k plnosti Božej pravdy“ ${ }^{87} \mathrm{Na}$ tejto ceste sa stretáva s inými pútnikmi, objavuje „stopy“ jednej a tej istej "pravdy" a podla príkladu Boha vstupuje do dialógu spásy - toho dialógu, ktorý Boh vedie s ludstvom od počiatku času - aby sa v ňom otvárala pre plnšie porozumenie „Božejpravdy“. Na tejto perspektíve potom spočíva teologická hodnota medzináboženského dialógu. ${ }^{88}$

Dokument Učitel'ského úradu Cirkvi Dialóg a oblasovanie konštatuje, že záväzok Cirkvi viest’ dialóg, odvodený $\mathrm{z}$ iniciatívy Boha, vstupujúceho do dialógu s ludstvom a z príkladu Ježiša Krista, „zostáva peoný a nemenny “ aj „napriek početným tažkostiam“. 89

Dokument súčasne charakterizuje dialóg a ohlasovanie ako „dvojitý záväzok" Cirkvii a všetkým krestanom adresuje pozvanie, aby sa "osobne zapojili do týchto dvoch spôsobov uskutočnovania jediného poslania Cirkvi“..91

\footnotetext{
85 Lumen gentium, čl. 5.

86 Ibid., čl. 48.

87 Dei verbum, čl. 8.

88 Dialóg a oblasovanie, čl. 33 - 41.

89 Ibid., čl. $53-54$.

90 Ibid., čl. 89.

91 Ibid., čl. 82.
} 


\section{Perspektívy medzináboženského dialógu}

Dialogické iniciatívy pokoncilovej Cirkvi nemajú v dejinách obdobu. Jedinečné sú čo do svojho obsahu, ale aj rozsahu. $V$ tejto kapitole si predstavíme niektoré zo širokého spektra dialogických iniciatív v kontexte piatich svetových náboženstiev. Nezávisle od ich podoby, iniciatívy dialogického typu predstavujú alternatívu konfrontácie a konfliktu, ktoré po stáročia sprevádzali kontakty medzi náboženstvami. Dialogický model medzináboženských vztahov otvára novú perspektívu spoločného postupu, napríklad proti kríze hodnôt, manifestujúcej sa v konzumnej mentalite súdobých spoločností, a v spoločnom úsilí o rehabilitáciu hodnôt na náboženskom základe (finalita) prostredníctvom stretnutia a spolupráce stúpencov odlišných náboženských tradícií (vztahovost').

\subsection{Perspektívy katolícko-hinduistického dialógu}

Vztah katolíckych krestanov k stúpencom tradičných náboženstiev indického subkontinentu, ktoré Európania koloniálneho obdobia európskych dejín začali označovat' termínom binduizmus, sa po Druhom vatikánskom koncile nesie v znamení obratu od misie $\mathrm{k}$ dialógu. Tento obrat predstavuje zásadnú zmenu perspektívy v katolícko-hinduistických vztahoch. 
Obrat od misie k dialógu symbolicky znázorňuje fotografia z medzináboženského stretnutia na Srí Lanke z 13. januára 2015, na ktorom pápeža Františka víta brahman Kurukkal Šiva Šrí Mahadéva. Išlo o prvú návštevu pápeža na Srí Lanke po 20. rokoch a symbolické obnovenie vzájomných vztahov medzi predstavitelmi Katolíckej cirkvi a tamojšieho spoločenstva hinduistov.

\subsubsection{Náčrt dejín krest’anskej misie v Indii}

Dejiny krestanskej misie na indickom subkontinente siahajú do ranokrestanských čias. Krestania v Indii patria $\mathrm{k}$ troch tradíciám - sýrskej, rímskokatolíckej a protestantskej. ${ }^{92} \mathrm{~K}$ starobylému sýrskemu rítu sa hlásia najmä tomášovski krestania; katolícki a protestantskí krestania sú prevažne potomkami konvertitov z obdobia európskej kolonizácie Indie v novoveku.

Hoci pôvod tradície tomášovských krestanov v súčasnosti nemožno historicky potvrdit ani vyvrátit', pretože nie je vierohodne doložené, či a ako apoštol Tomáš v Indii pôsobil, tomášorski krestania odvodzujú svoj pôvod od príslušníkov troch vy̌ších spoločenských stavov (štyri varny, „farba“, resp. džátí, „Zrodenie“, podskupiny várn; brahmani, kšatrijovia, vaišjovia, šúdrovia), ktorých mal na krestanstvo obrátit sám apoštol Tomáš po svojom príchode do Indie $(50-52$ ?).

92 Počet krestanov v Indii sa odhaduje na 32 miliónov, čo v roku 2010 predstavovalo 2,6 \% populácie Indie a 1,5 \% celkovej populácie krestanov (Pew Research Center 2011). 
Od 4. storočia udržiava táto komunita prvých indických krestanov úzke vztahy so sýrskou cirkvou, ktoré tradícia spája s príchodom Tomáša z Kány do Indie okolo roku 345. ${ }^{93}$ Podla tradície Tomáš z Kány zreorganizoval komunitu tomášovských krestanov a začlenil ju pod jurisdikciu sýrskej cirkvi ako malabarskú cirkev. Liturgickým jazykom sýrsko-malabarskej cirkvi je preto sýrčina a jej obrad je antiochijský. Takto vznikla originálna tradícia, ktorá je súčasne indická aj krestanská, a pritom plne integrovaná do majoritnej hinduistickej spoločnosti. Až na výnimky boli dejiny vzájomných vztahov tomášovských krestanov a stúpencov tradičných indických náboženstiev pokojné a harmonické.

$S$ príchodom Portugalčanov na indický subkontinent v roku 1498 začína menej pokojná etapa kontaktu krestanov s domorodým obyvatel'stvom Indie. Portugalčania vedení Vasco da Gama mali dva ciele - priamy obchod s Indiou, ktorý dovtedy ovládali arabskí a benátski obchodníci, a šírenie krestanstva, ktorého patrónom bol, na základe patronátnych zmlúv so Svätou stolicou, portugalský panovník.

Spoločne s obchodníkmi a vojakmi preto prichádzali do Indie aj kňazi. Spočiatku slúžili prevažne portugalským osadníkom. Rímskokatolícka misia sa v Indii šíri až po príchode františkánov v roku 1517, ktorí sa stávajú jej nositelmi. Väčšina konvertitov v tomto období zrejme

93 Tomáš z Kány bol krestanský obchodník z Perzie, ktorý sa spolu s d’alšími približne sedemdesiatimi sýrskymi rodinami usadil v Indii. Počet sedemdesiat sa obvykle interpretuje symbolicky, podobne ako je tomu v prípade sedemdesiatich prekladatelov Septuaginty (LXX, rabínsky preklad židovskej Biblie $\mathrm{z}$ hebrejčiny do gréčtiny), alebo sedemdesiatich učeníkov Ježiša. 
pochádza z nižších spoločenských stavov (šúdrovia). Konverzia im ponúkla možnost’ získat' spoločenské výhody a ochranu portugalskej koruny.

Katolícka misia v Indii zaznamenala svoj najväčší rozmach s príchodom jezuitov. Prví jezuiti na čele s Františkom Xaverským vstúpili na pôdu indického subkontinentu v roku 1542. Pre misijné pôsobenie jezuitov bolo od počiatku charakteristické úsilie o inkulturáciu - snaha ponúknut' krestanskú vierouku vo forme zrozumitelnej domorodým adresátom (akomodácia). Jezuiti sa preto oboznamovali s miestnymi kultúrami, učili sa miestne jazyky, prekladali do nich pôvodne latinské texty modlitieb a podobne.

Príkladom úspešnej akomodácie bola misia talianskeho jezuitu Roberta de Nobili (1577 - 1656). Na rozdiel od františkánskych misionárov sa De Nobili zameral na pôsobenie medzi brahmanmi v juhoindickom meste Madurai a tomu prispôsobil aj svoj spôsob života: odieval sa do tradičného šafranového odevu indických sannjásinov (mendikantov), stravoval sa vegetariánsky, osvojil si sanskrit. Hoci bol jeho spôsob misie úspešný, narazil na ostrú kritiku niektorých cirkevných autorít. Rastúca jezuitská misia v Indii napokon skončila predčasne v roku 1773 v dôsledku zrušenia Spoločnosti Ježišovej rozhodnutím Svätej stolice.

$\mathrm{S}$ úpadkom portugalskej moci $\mathrm{v}$ Indii v 18. storočí upadal aj vplyv rímskokatolíckej misie, ktorá sa vo všeobecnosti zameriavala na nižšie spoločenské stavy a nedokázala oslovit’ nositelov starobylých a kultúrne vyspelých náboženských tradícii Indie.

Od 17. storočia sa v Indii presadzujú d’alšie európske mocnosti - Nizozemsko, Vel'ká Británia a Francúzsko. Ich 
obchodné záujmy spočiatku reprezentujú Východoindické spoločnosti - nizozemská Zjednotená východoindická spoločnost' (založená v roku 1602), britská Východoindická spoločnost' (založená v roku 1600) a francúzska Východoindická spoločnost' (založená v roku 1664).V mocenskom boji o ovládnutie Indie nakoniec získali prevahu Briti a od roku 1858 tak hovoríme o Britskej Indii.

Obchodné misie koloniálnych mocností boli sprevádzané krestanskými misiami. $\mathrm{V}$ prípade Holandanov a Britov to boli misie protestantské. Protestantské misie pôsobili predovšetkým prostredníctvom školského systému (misijné školy) a ohlasovania založenom na prekladoch Biblie do miestnych jazykov. K nim sa v 20. storočí pridávajú aj misie evanjelikálnych cirkví.

Od začiatku 19. storočia dochádza $\mathrm{k}$ zaujímavému úkazu - objavujú sa masové konverzie ku krestanstvu medzi dalitmi, „nedotknutelnými“ - najnižšou spoločenskou vrstvou indickej spoločnosti, stojacou mimo tradičného stavovského poriadku.

Napriek niektorým úspechom krestanská misia $v$ novoveku nemala zásadný úspech pri pokrestančení Indie zrejme aj preto, lebo bola spojená s koloniálnou mocou - najprv s portugalskými katolíkmi, neskôr prevažne $s$ britskými protestantmi - a krestanom sa nepodarilo zbavit' stigmy tohto spojenia.

$\mathrm{V}$ reakcii na misijné pôsobenie krestanských cirkví v Indii sa ako výraz národného a náboženského obrodenia na indickom subkontinente 19. storočia formuje neobinduizmus. Nositelmi neohinuistických ideí boli obrodné hnutia ako Brahma-samádž (Spolok veriacich v Brahma), Árja-samádž (Spolok Árjov), Rámakršnova misia a iné. Významným predstavitelom neohinduizmu bol Mahátmá 
Gándhí, symbol národno-oslobodzovacieho hnutia Indov, ktoré vyvrcholilo 15. augusta 1947, ked' India získala nezávislost' od Vel'kej Británie a následne 26. januára 1950, vznikla samostatná Indická republika.

Neohinduistické hnutie prejavuje malý záujem o medzináboženský dialóg. Nezáujem o dialóg zrejme súvisí s tradične hinduistickým inkluzivizmom, ktorý vykazuje tendenciu zahŕňat rôznorodé náboženské tradície do velkej univerzalistickej syntézy rôznych manifestácií posvätna.

\subsubsection{Obrat k dialógu}

Oficiálnemu obratu Katolíckej cirkvi k dialógu s hinduizmom, promulgovanom na Druhom vatikánskom koncile, predchádzali desatročia príprav a iniciatív angažovaných jednotlivcov. Medzi priekopníkov katolícko-hinduistického dialógu v Indii patria dve mimoriadne osobnosti - francúzsky kňaz Jules Monchanin (18951957) a francúzsky benediktín Henri Le Saux (1910 1973), známym tiež pod svojím indickým menom svámí Abhikšiktanada. V roku 1938 v indickom štáte Tamil Nádu spoločne založili originálny projekt benediktínskeho ášramu, ktorý dostal meno Satčitánanda ášram alebo tiež Šantivam. Cielom zakladatelov bolo vytvorit integrovaný model benediktinskeho klästora a indického ášramu.

Iný inovatívny projekt integrácie krestanského a indického mnišstva predstavuje Kurisumala âšram v indickom štáte Kérala, ktorý vznikol z iniciatívy belgického cisterciána Francisa Mahieu a anglického benediktína Bede Griffithsa v roku 1956. Tento ášram je tiež unikátny tým, 
že integruje európsku cisterciánsku tradiciu s indickou tomásooskou, sýrsko-malabarskou tradiciou.

Spomedzi protagonistov katolícko-hinduistického dialógu na intrareligióznej, resp. interspirituálnej rovine (spirituálny dialóg) sa záujmu širšej verejnosti tešia napríklad jezuita Anthony de Mello (1931 - 1987) či Wayne Teasdale (1945 - 2004).

Dialogickú politiku Katolíckej cirkvi, sformulovanú na Druhom vatikánskom koncile a implementovanú počas pontifikátov pokoncilových pápežov, predznamenal prejav pápeža Pavla VI., ktorý adresoval hinduistom počas svojej návštevy Indie 3. decembra 1964: „Vaša krajina je krajinou starej kultúry, koliskou vel'kých náboženstiev, vlastou národa, ktorý v stálej túžbe, hlbokom rozjimani, v mlíani a vo vrúcnych hymnických modlitbách hl'adal Boha. Len zriedka bola táto túžba po Bohu vyjadrená slovami tak plnými adventného ducha, ako sú tie, ktoré boli zaznamenané vo vašich svätých knihách mnoho storoči pred Kristom: Od neskutočného ved'ma k skutoćnému; z temnoty ved' ma k svetlu; zo smrti ma ved' k nesmrtelnosti (Bribadaranjaka upanišada 1, 3, 28). "94

Pozíciu Katolíckej cirkvi vo vztahu k hinduizmu doktrinálne záväzným spôsobom formuluje deklarácia Druhého vatikánskeho koncilu Nostra aetate o vztahu Cirkvi k nekrestanským náboženstvám. Deklarácia sa

94 "This visit to India is the fulfilment of a long cherished desire. Yours is a land of ancient culture, the cradle of great religions, the home of a nation that has sought God with a relentless desire, in deep meditation and silence, and in hymns of fervent prayer. Rarely has this longing for God been expressed with words so full of the spirit of Advent as in the words written in your sacred books many centuries before Christ: ,From the unreal lead me to the real; from darkness lead me to light; from death lead me to immortality'(Br. 1, 3, 28)." Pavol VI. 1964. 
$\mathrm{k}$ hinduizmu vyslovuje $\mathrm{v}$ širšom kontexte spoločne s buddhizmom a d’alšími bližšie nešpecifikovanými náboženstvami v článku 2 nasledovne:

„Od dávnych čias až podnes rozličné národy určitým spôsobom vnimajú tajomnú silu, ktorá účinkuje vo vývoji vecí a v udalostiach ludskébo života. Niektoré uznávajú najvyššie božstvo, pripadne Boha Otca. Toto vnimanie a poznanie preniká celý ich život blbokým náboženským citom. Náboženstvá sa v súlade s kultúrnym pokrokom pokúšajú odpovedat'na tieto problémy čoraz presnejšimi pojmami a kultivovanejšim jazykom. Privrženci hinduizmu skúmajú Božie tajomstvo a vyjadrujú ho nevyčerpatelnou plnostou mýtov a prenikavým fllozofickým hl'adanim. Hladajú oslobodenie od uzkosti našej existencie asketickým spôsobom života či hlbokým rozjimanim alebo sa s láskou utiekajú $k$ Bobu. "95

Koncil naznačuje styčné body katolícko-hinduistického dialógu bez toho, aby zdôrazňoval jeho sporné body, a tak ide katolíckym krestanom príkladom v dialógu. Fotodokumentácia zo stretnutia pápeža Františka a brahmana Kurukkal Šiva Šrí Mahadévu z úvodu tejto podkapitoly názorne ilustruje myšlienku o obrate Katolíckej cirkvi od misie k dialógu pri zachovaní ich jednoty, a to ako pozvania vydávat' svedectvo o Kristovi a súčasne objavovat znamenia jeho univerzálnej spásnej prítomnosti.

95 Nostra aetate, čl. 2. 


\subsection{Perspektívy katolícko-buddhistického dialógu}

Podoby vztahu katolíckych krestanov k stúpencom spektra buddhistických tradícií $\mathrm{v}$ pokoncilovom období rozšíril model spoločného putovania. Paradigma spoločného putovania predstavuje zásadnú zmenu perspektívy v katolícko-buddhistických vztahoch.

Myšlienku spoločného putovania názorne ilustruje fotografia zo stretnutia 14. dalajlámu Tändzina Gjamccho, benediktínskeho mnícha Davida Steindl-Rasta a trapistického mnícha Thomasa Keatinga, ktoré sa uskutočnilo v americkom Bostone 14. októbra 2012. Fotografia zachytáva prejav vzájomnej úcty a rešpektu medzi 14. dalajlámom a bratom Steindl-Rastom. ${ }^{96}$

\subsubsection{Historický prierez vzájomných vztahohov}

Úcta a rešpekt však necharakterizovali vždy vzájomné vztahy medzi katolíkmi a buddhistami; tie sa skôr vyznačovali neporozumením na oboch stranách.

96 Dalajláma je politickým reprezentantom tibetskej exilovej vlády a náboženským predstavitelom školy Gelugpa, jednej zo štyroch hlavných doktrinálnych škôl a mníšskych tradícií tibetského buddhizmu. David Steindl-Rast je benediktín rakúskeho pôvodu žijúci v USA, ktorý patrí k najvýznamnejším súčasným protagonistom kontemplatívnej spirituality katolíckej proveniencie a katolícko-buddhistického dialógu. 
$\mathrm{Aj}$ ked' história kontaktov medzi predkrestanskou $\mathrm{Eu}-$ rópou a buddhistickými regiónmi Ázie siaha temer k počiatkom buddhizmu v Indii, záujem Európanov o buddhizmus prinieslo až 19. storočie. ${ }^{97}$ Antickému Grécku sprostredkovali kontakt s buddhizmom buddhistickí misionári, ktorých v polovici 3. storočia pred Kr. vyslal do Európy král Ašóka, najvýznamnejší staroveký patrón buddhizmu. Písomným svedectvom o vzájomných kontaktoch je slávny, hoci nekánonický buddhistický spis $M i-$ lindove otázky (páli Milinda Pañha), pochádzajúci pravdepodobne $\mathrm{z}$ 1. storočia pred $\mathrm{Kr}$. Jeho obsahom je rozhovor medzi králom Milindom (gr. Menandros I.), vládcom grécko-indického královstva, a buddhistickým mníchom Nagasénom.

V krestanskej literatúre sa prvá zmienka o Buddhovi objavuje v spise Klementa Alexandrijského Strómateis (gr. Koberce) približne z roku 200. S pádom Západorímskej ríše v 5. storočí a expanziou islamu v 7. storočí však vzájomné kontakty ustávajú a obnovujú sa až v 13. storočí v súvislosti s rozvojom obchodu medzi Európou a Ďalekým východom. Jeho počiatky legendárnou formou zachytávajú, medzi iným, spomienky benátskeho kupca a cestovatela Marca Pola (1254 - 1324), ktorý zo svojich ciest po Mongolmi ovládanej Č́ne priniesol správy o buddhizme.

Novoveká etapa vzájomných kontaktov krestanov a buddhistov bola spojená s európskym kolonializmom. Krestanská misia na tradične buddhistických územiach sa v tomto dejinnom období rozvíjala najmä s príchodom jezuitov. V roku 1549 vstúpil na pôdu Japonska prvý krestanský misionár jezuita František Xaverský (1506 - 1552).

97 Lenoir 2003, s. 13. 
Pre jeho misijné pôsobenie bolo charakteristické úsilie o inkulturáciu (akomodácia).

Iný jezuita Matteo Ricci (1552 - 1610) bol exponentom úspešnej jezuitskej misie v Č́ne, kde sa opät uplatnila jezuitská metóda akomodácie. Ricci v krajine pôsobil temer 30 rokov, od roku 1582 až do svojej smrti v roku 1610. Spoločne so svojím reholným spolubratom Michaelom Ruggierim zostavil prvý ćínsko-portugalský slovník v dejinách; Ricci bol prvým Európanom, ktorému sa podarilo vstúpit do ,Zakázaného mesta' a získat audienciu na dvore čínskeho cisára.

Záujem európskych intelektuálov o buddhizmus sa postupne prebúdzal od začiatku 19. storočia. Od počiatočných nihilistických interpretácií (Arthur Schopenhauer, Friedrich Nietzsche a iní) prerástol do devocionálnych interpretácií, sprevádzaných vlnou konverzií $\mathrm{k}$ buddhizmu (Edwin Arnold a pod.). K popularizácii buddhizmu v kontexte vlastnej univerzalistickej vízie náboženstva prispela aj Teozofická spoločnost' (Helena Blavatská, Henry Olcott, 1875). Akademický záujem o buddhizmus sa rozvija od konca 19. storočia a nachádza svoj výraz v lingvistickom, historickom, orientalistickom a religionistickom bádaní. ${ }^{98}$

V 20. storočí sa objavili nové, celkom jedinečné podoby kontaktu buddhistov a krestanov, ako ich napríklad, predstavuje škola japonského zenového buddhizmu Sanbó Kjódan, ktorá sa odklonila od zenovej tradície a sprístup-

98 V roku 1881 vznikla v Londýne The Pali Text Society s cielom prekladat' a publikovat texty pálijského kánonu. Akademický záujem o Orient na území prvej Československej republiky získal inštitucionálne zázemie v roku 1922, ked’ bol v Prahe založený Orientálny ústav za podpory vtedajšieho prezidenta Tomáša Garrique Masaryka. 
nila zenový výcvik najprv buddhistickým laikom, neskôr aj nebuddhistom. ${ }^{99}$ Od roku 1970 róši Kóun Jamada, nástupca zakladatela školy majstra Jasutamiho, umožnil absolvovat' zenový výcvik a získat oprávnenie vyučovat’ zen aj krestanom bez toho, aby od nich vyžadoval konverziu k buddhizmu. Misiou a vyučovaním zenu tak boli oficiálne poverení príslušníci nebuddhistickej tradície.

Prvým krestanom, ktorý absolvoval zenový výcvik pod vedením majstra Jamadu, bol jezuita Hugo Makibi Enomiya-Lassalle. Nasledovali d’alší krestanskí záujemcovia o zen - kňazi, mnísi, rehol'níci, reholné sestry, laici - spolu viac ako dvadsat krestanov len za Jamadovho pôsobenia (do roku 1989), z nich vyše dvanást' neskôr získalo oficiálne poverenie vyučovat zen.

Forma spojenia zenovej a krestanskej spirituality, ktorá tak vznikla, nemá v dejinách obdobu. Navyše nikdy predtým nebolo možné, aby predstavitel' jednej duchovnej tradície odovzdával učenie inej duchovnej tradície tak, ako je tomu v prípade školy Sanbó Kjódan. Druhá polovica 20. storočia priniesla vskutku epochálne zmeny na buddhistickej aj krestanskej strane a otvorila úplne novú perspektívu vzájomného kontaktu, ktorú tu nazývame spoločné putovanie.

99 Školu Sanbó („tri poklady“) Kjódan („spoločenstvo“) založil zenový majster Hakuun Rjóko Jasutami v roku 1954 v línii japonskej zen-buddhistickej tradície Sótó, spojenej s prvkami druhej vel'kej japonskej tradície zenu Rinzai. 


\subsubsection{Spoločné putovanie}

Podobne ako v prípade hinduizmu, pozíciu Katolíckej cirkvi vo vztahu $\mathrm{k}$ buddhizmu doktrinálne záväzným spôsobom vyjadruje deklarácia Druhého vatikánskeho koncilu Nostra aetate o vztahu Cirkvi k nekrestanským náboženstvám. Deklarácia venuje buddhizmu jedinú, ale obsažnú vetu bezprostredne potom, ako sa dvomi vetami vyslovuje $\mathrm{k}$ hinduizmu a predtým, ako všeobecne reflektuje iné, bližšie nešpecifikované náboženstvá:

„Buddhizmus vo svojich rozmanitých podobách uznáva základnú nedostatočnost toh to menlivého sveta a uči ceste, ktorou by ludia mohli s nábožnou a dôvernou myslou dosiahnut stav dokonalého oslobodenia alebo dôjst' $k$ vrcholnému osvieteniu č už vlastným úsilim, alebo vd'aka pomoci zhora.

Rovnako aj iné náboženstvá, ktoré sa všade na svete rozličným spôsobom usilujú prekonat nespokojnost' ludskébo srdca, predkladajú rozmanité cesty, to jest učenia, životné pravidlá a posvätné obrady. " ${ }^{00}$

Formuláciu venovanú buddhizmu do koncilového dokumentu navrhli jezuiti Heinrich Dumoulin, teológ a historik náboženstiev so špecializáciou na zenový buddhizmus, Paul Pfister, teológ a odborník na buddhizmus, a Hugo M. Enomiya-Lassalle, znalec katolíckej a zenovej spirituality. Vo svojom vyjadrení cirkevný snem poukazuje na styčné body medzi krestanstvom a buddhizmom, rozlišujúc medzi buddhizmom ponorenia a buddhizmom viery,

100 Nostra aetate, čl. 2. 
ked' hovorí, že buddhizmus dosahuje svoj ciel bud' „vlastným úsilim“, alebo „za pomoci zhora“.

Obratu Katolíckej cirkvi k dialógu s buddhizmom predchádzali desatročia príprav a iniciatív angažovaných jednotlivcov tak, ako tomu bolo aj v prípade iných náboženských tradícií. Vo vzájomnom dialógu sa angažovali, prípadne sa angažujú jezuiti Hugo M. Enomiya-Lassalle, William Johnston, Anthony de Mello či Heinrich Dumoulin, benediktín David Steindl-Rast, trapista Thomas Merton, teológovia Hans Waldenfels a Hans Küng, buddhisti 14. dalajláma Tändzin Gjamccho, Thich Nhat Hanh alebo Masao Abe, aby sme spomenuli aspoň niektorých.

Priekopníkom katolícko-buddhistického dialógu na spirituálnej úrovni bol Hugo Makibi Enomiya-Lassalle (1898 - 1990). Páter Lassalle bol zrejme vôbec prvý katolícky kňaz, ktorý praktizoval zazen pod vedením japonských zenových majstrov, bol tiež prvým kňazom v dejinách, ktorý získal autorizáciu vyučovat zen priamo od japonskej zen-buddhistickej tradície, a napokon bol prvým autorom, ktorý písal o uplatnení zenu v katolíckej spiritualite na základe vlastnej skúsenosti. Takto sa Hugo Lassalle stal stelesnením obratu Katolíckej cirkvi k spoločnému putovaniu vo vztahu $\mathrm{k}$ buddhizmu.

Fotografia zo stretnutia 14.dalajlámu Tändzin Gjamccho a benediktínskeho mnícha Davida Steindl-Rasta v americkom Bostone v roku 2012 je dalším obrazom spoločného putovania katolíckych krestanov a buddhistov, založenom na vzájomnej úcte a rešpekte pri všetkej odlišnosti. 


\subsection{Perspektívy katolícko-židovského dialógu}

Druhá polovica 20. storočia priniesla zásadný obrat aj vo vztahoch medzi krestanmi a židmi - obrat od konfliktu $k$ dialoggu. Symbolom tohto obratu je fotografia $\mathrm{z}$ historického stretnutia pápeža Jána Pavla II. a hlavného rabína mesta Rím Elio Toaffa pri príležitosti pápežovej návštevy Vel'kej synagógy v Ríme 13. apríla 1986. Ján Pavol II. bol prvým pápežom $\mathrm{v}$ dejinách, ktorý túto synagógu navštívil a bol to aj pápež, ktorý sa zapísal do análov histórie ako angažovaný promótor katolícko-židovského dialógu.

\subsubsection{Dejiny konfliktu}

Vztahy medzi židmi a krestanmi počas storočí charakterizoval konflikt. Jeho počiatky siahajú k samotným začiatkom krestanstva - prví krestania boli etnickí Židia, Ježiš bol Žid. Jadrom židovsko-krestanského konfliktu je teologický spor o status Ježiša z Nazareta: Ježiš je pre krestanov Kristus (gr. kerygma), uholný kameň krestanstva, kým pre židov je kameñom úrazu.

S vystúpením proroka Muhammada vstupuje na javisko dejín nový velký geopolitický a náboženský hráč - islam. Od svojho vzniku je islam globálnym protihráčom krestanstva. Islamský štát garantuje „ludom Kniby“, teda židom a krestanom, nedotknutelnost života, majet$\mathrm{ku}$ a vierovyznania výmenou za daň a spoločenský status „chránených menšin“", teda v istom zmysle občanov druhej 
kategórie. Pokial ide o Židov, v islamskom prostredí majú pred krestanmi istú výhodu - sú etnicky a kultúrne blízki arabskému etniku, ktoré stálo pri zrode multikultúrnej moslimskej civilizácie.

Príkladom relatívne harmonického spolužitia židov a moslimov bolo maurské Španielsko, ktoré v 10. storočí prevzalo štafetu nového svetového centra islamu po Bagdadskom abbásovskom kalifáte. V Córdobe sa židovská elita zapojila sa do hospodárskeho, politického a kultúrneho života mesta, osvojila si arabský jazyk, prijala maurský odev i maurské zvyky.

Od 11. storočia sa na krestanskom Západe šíri antiislamizmus (xenofóbia voči moslimom) spoločne s antijudaizmom (xenofóbia voči stúpencom židovstva) a antisemitizmom (xenofóbia voči Židom, príslušníkom židovského etnika). Európu zaplavujú vlny protižidovského sentimentu. V roku 1394 boli Židia vyhnaní z Francúzska a ich majetky boli skonfiškované. Po dobytí Granady, poslednej bašty islamu na Pyrenejskom polostrove, v roku 1492 boli všetci Židia postavení pred vol'bu: konvertovat alebo emigrovat'. Tisíce Židov opustili krajinu, ale väčšina prijala krst. Židia španielskeho pôvodu (sefardskíŽidia) emigrovali najmä do Nizozemska, Talianska a osmanského Turecka. V dôsledku dalších vín represií v Nemecku 15. a 16. storočia nastal úpadok severoeurópskeho židovstva. Židia nemeckého pôvodu (aškenázi) migrovali na Východ. V 16. a 17. storočí sa tak novým centrom európskeho židovstva stalo Polsko - v tých časoch ekonomicky menej rozvinutá krajina, kde boli Židia nositelmi ekonomického pokroku.

Voči antijudaistickým postojom neboli imúnne ani reformované cirkevné obce, vo viacerých protestantských regiónoch sa však postavenie Židov zmenilo k lepšiemu. 
Reformácia priniesla zóny tolerancie - ekonomicky silné, priemyselne rozvinuté oblasti severnej Európy - najskôr Nizozemsko, neskôr Anglicko. Práve safardskí Židia, ktorí emigrovali zo Španielska, pomohli zvítazit Nizozemsku v obchodnej vojne so Španielskom a Portugalskom v 17. storočí a stáli pri počiatkoch burzovej ekonomiky najprv v Amsterdame, potom v Londýne. Židovskí obchodníci boli aj pri zakladaní európskeho koloniálneho panstva v Strednej a Južnej Amerike. Rok 1492 nebol len rokom vyhnania Židov zo Španielska, ale aj rokom objavenia Ameriky. V roku 1654 prichádza prvých 32 židovských migrantov z Brazílie do novozaloženého Nového Amsterdamu (od roku 1664 New York) a v roku 1729 tam ich potomkovia postavia prvú židovskú synagógu v Severnej Amerike ako symbol náboženskej slobody pre Židov.

\subsubsection{Obrat od konfliktu k dialógu}

Európe priniesla verejnú zmenu vztahu k Židom až druhá polovica 20. storočia. Na strane Katolíckej cirkvi bol jej oficiálnym promótorom Ján XXIII. (pontifikát 1958 - 1963) - pápež, ktorý zvolal Druhý vatikánsky koncil $(1962-1965)$.

Jeho nástupca na pápežskom stolci Pavol VI. (pontifikát 1963 - 1978) zriadil ešte počas trvania cirkevného snemu Sekretariát pre nekrestanov (1964; od roku 1989 Pápežská rada pre medzináboženský dialóg) a do jeho „rodného listu" symbolicky vložil odkaz koncilu - ono aggiornamento - zdnešnenie vizionára Cirkvi Jána XXIII. Poslaním sekretariátu sa tak stalo rozvijat vztahy reprezentácie Ka- 
tolíckej cirkvi so stúpencami nekrestanských náboženstiev na dialogickom princípe.

Verný odkazu Jána XXIII. ostatný cirkevný snem prijal deklaráciu o vztahu Cirkvi k nekrestanským náboženstvám Nostra aetate. Stalo sa tak 28. októbra 1965 počas jedného $\mathrm{z}$ jeho posledných zasadnutí. Nostra aetate ohlasuje zmenu postoja Katolíckej cirkvi k judaizmu. $V$ článku 4 dokument hovorí o "pute“, ktoré spája „lud Novej zmluvy“, krestanov, s "potomkami Abraháma“, so židmi, a čo je zvlášț významné, po prvýkrát $\mathrm{v}$ histórii tu koncilový dokument odmieta kolektívnu vinu Židov za smrt' Ježiša, prijíma zodpovednost' za všetky prejavy antijudaizmu a antisemitizmu zo strany Cirkvi v dejinách a vyjadruje za svoje ospravedlnenie: Cirkev "vedomá si svojho spoločného dedičstva so židmi, "výslovne uvádza, „vyslovuje polutovanie nad nenávistou voči Židom, prenasledovaniami a prejavmi antisemitizmu, kedykolvek a z ktorejkolvek strany sa vyskytli".

Proti konfrontácii potom koncil stavia dialóg a vzájomné poznávanie. ${ }^{101}$ Dogmatická konštitúcia o Cirkvi Lumen gentium sa vyslovuje oceňujúco o židovstve ako o národe, ktorý „dostal zmluvy a prislúbenia a z ktorého sa podla tela narodil aj Kristus (porov. Rim 9, 4-5); národ milovaný, vyvolený za zásluby otcor, lebo Božie dary a povolanie sú neodvolatelné (porov. Rim 11, 28 - 29). “102

$\mathrm{O}$ význame vztahov s judaizmom pre Katolícku cirkev svedčí aj fakt, že pápež Pavol VI. zriadil osobitnú Komisiu pre náboženské vztahy so Židmi (1974) s poslaním imple-

101 Kedže „krestania a židia majú také velké spoločné duchovné dedičstvo, ... tento posvätný cirkevný snem chce napomáhat' a odporúčat' ich vzájomné poznávanie a úctu, čo možno docielit' najmä biblickými a teologickými štúdiami a bratským dialógom". Nostra aetate, čl. 4.

102 Lumen gentium, čl. 16. 
mentovat usmernenia Druhého vatikánskeho koncilu vo vztahu k judaizmu, predovšetkým tie, ktoré sú obsahom článku 4 deklarácie Nostra aetate. ${ }^{103}$

Komisia pre náboženské vzt’ahy so židmi vydala pri príležitosti osláv 50. výročia Nostra aetate dokument pod názvom Božie dary a povolanie sú neodvolatelné. Tento dokument nadväzuje na predchádzajúce pokoncilové dokumenty Katolíckej cirkvi vo vztłahu k judaizmu, zdôrazňuje jedinečné miesto židovstva $\mathrm{v}$ dialogickej politike Cirkvi, rekapituluje historický progres v katolícko-židovskom dialógu dosiahnutý počas ostatných desatročí a zdôrazňuje, že „Katolicka cirkev už neuskutočňuje ani neodporúča žiadnu oficiálnu misijnú aktivitu vo vzt’ahu kžidom, "pretože je „teologicky nesporné, že židia majú účast' na Božej spáse... Avšak ako ju možno dosiahnut' bez viery v Ježiša Krista ostáva pre nás nepochopitelným Božím tajomstvom. "104

Katolícka pozícia je v tejto veci totožná s pozíciou niektorých reformovaných cirkví tak, ako ju vyjadruje dokument Cirkev a Izrael: príspevok reformovaných cirkvi Európy k vzt'ahu krestanov a židov, kde sa uvádza, že „krest'ania sa zdržiavajú každej aktivity zameranej na obrátenie židov ku krestanstou" 105

103 Komisia vznikla na základe transformácie Úradu pre katolíckožidorské vztahy, ktorý bol zriadený krátko po skončení koncilu v roku 1966.

104 "[T]he Catholic Church neither conducts nor supports any specific institutional mission work directed towards Jews... That the Jews are participants in God's salvation is theologically unquestionable, but how that can be possible without confessing Christ explicitly, is and remains an unfathomable divine mystery." Pontifical Council for Promoting Christian Unity 2015.

105, [T]o refrain from any activity directed specifically to converting Jews to Christianity". Leuenberg Church Fellowship 2001. 
Novú kapitolu v dejinách vztahov Katolíckej cirkvi k judaizmu otvoril Ján Pavol II. (pontifikát 1978 - 2005). Tento slovanský pápež prijal za svoju dialogickú politiku Druhého vatikánskeho koncilu a aktívne sa angažoval v medzináboženskom dialógu, zvlášt v dialógu so židovstvom. Ján Pavol II. patril k ostrým kritikom antisemitizmu a antijudaizmu a sústavne sa zasadzoval za odsúdenie genocídy židovského národa. Polský pápež sa angažoval i politicky pri diplomatickom riešení izraelsko-palestínskeho konfliktu (1990), ako aj pri nadviazaní diplomatických vztahov Svätej stolice a Izraela (1993) a Svätej stolice a Organizácie pre oslobodenie Palestíny (1994).

Z iniciatívy Jána Pavla II. sa, okrem iného, uskutočnili dve celkom jedinečné medzináboženské modlitbové stretnutia v Assisi (27. október 1986, 24. január 2002), ktorých sa zúčastnili zástupcovia rôznych náboženstiev, aby spoločne držali celodenný pôst a modlili sa za mier vo svete každý svojím spôsobom a podla svojich zvyklostí, zatial' čo ostatní boli s rešpektom prítomní pri ich modlitbách.

Na pôsobenie Jána Pavla II. na poli katolícko-židovského dialógu nadviazal Benedikt XVI. (pontifikát 2005 - 2013). Počas svojho pontifikátu Benedikt navštívil tri synagógy - v Kolíne (2005), v New Yorku (Park East, 2008) a v Ríme (Velká synagóga, 2010) - a vo svojich príhovoroch opakovane vyzýval $\mathrm{k}$ lepšiemu vzájomnému poznaniu, úprimnému dialógu, bratským vztahom a svedectvu viery.

Ked' 28. februára 2013 Benedikt XVI. rezignoval na svoj úrad a 13. marca 2013 konkláve volitelov zvolilo za pápeža kardinála Jorge Bergoglia, ktorý prijal meno František, dialogická politika Druhého vatikánskeho koncilu získala dalšieho angažovaného protagonistu. 
O Františkovej zainteresovanosti vo veci katolícko-židovského dialógu svedčí fakt, že hned’ po nástupe do úradu zaslal posolstvo židovskému spoločenstvu v Ríme. Krátko nato v apríli roku 2013 prijal pozvanie vtedajšieho izraelského prezidenta Šimona Peréza na návštevu Izraela, ktorá sa uskutočnila nasledujúci rok. Františka počas návštevy Svätej zeme a palestínskych území sprevádzali jeho argentínski priatelia - židovský rabín Abraham Skorka a moslimský imám Omar Abboud, aby spoločne niesli posolstvo mieru, zmierenia a dialógu medzi náboženstvami.

Z udalostí ostatných rokov spomeňme Františkovu návštevu Vel'kej synagógy v Ríme 17. januára 2017 počas Dřa dialógu medzi katolikmi a židmi, ktorou pápež potvrdil tradíciu založenú Jánom Pavlom II. - tradíciu dialógu postavenom na osobnom stretnutí.

Odkaz koncilu vo vztahu $k$ judaizmu je jednoznačný - je to odkaz zmierenia a dialógu. Pokonciloví pápeži Ján Pavol II., Benedikt XVI. a František nadviazali na tento odkaz a potvrdili učenie koncilu o personálnom poňatí dialógu, ktorý spočíva $v$ stretnutí autonómnych osôb, v nadviazaní osobného vzt'ahu, vo vytvorení spoločenstva.

\subsection{Perspektívy katolícko-moslimského dialógu}

Ked'v roku 622, pred temer 1400 rokmi, vznikla umma, prvé spoločenstvo moslimov, boli položené inštitucionálne základy fenomenálnej expanzie islamu i budúcej slávy arabskej civilizácie. Súčasne s tým sa objavili prvé známky moslimsko-krestanského konfliktu, ktorý trvá od vzniku islamu po súčasnost'. 
V historickej perspektíve sa dejiny vzájomných vztahov moslimov a krestanov javia ako dejiny vzájomnej rivality. Túto myšlienku výstižne ilustruje obraz, ktorý vošiel do dejín umenia pod názvom krestán a moslim brajú šach. Ide o miniatúru z Kniby hier, ktorú dal v roku 1283 vyhotovit Alfonz X., krestanský král Kastílie, Galície a Leonu. Skutočne, zdá sa, akoby moslimovia a krestania počas storočí vzájomného kontaktu hrali vel'kú šachovú partiu boja o moc na gigantickej šachovnici Stredomoria, Malej Ázie a Blízkeho východu.

V reakcii na arabské a neskôr islamské imperiálne výboje sa objavujú križiacke výpravy, reconquista, protiturecké vojny... A ked' sa v novoveku obráti karta moci, prichádza na rad európsky imperializmus a kolonializmus. Reformné hnutia $\mathrm{v}$ islame a radikalizáciu niektorých islamských spoločenstiev treba interpretovat' $\mathrm{v}$ tomto kontexte - teda i ako odpoved' na hegemóniu Západu v tradične moslimských krajinách.

Dvadsiate storočie však prinieslo zmenu. $\mathrm{Na}$ rozdiel od minulosti, neobmedzenú len regionálne, na ostrovčeky náboženskej slobody a spolupráce, ako v niektorých oblastiach stredovekého Španielska. V našich časoch nastal historický posun od konfrontácie $\mathrm{k}$ dialógu $\mathrm{v}$ moslimsko-krestanských vztahoch v globálnom rozsahu.

V roku 1948 vznikla Svetová rada cirkví so zámerom rozvíjat dialóg, krestansko-moslimský dialóg nevynímajúc. Krátko nato v roku 1955 vzniká Svetové spoločenstvo moslimov a krestanov s ciel'om priamo napomáhat' rozvoju vztahov medzi moslimami a krestanmi. Na strane Katolíckej cirkvi bol historickým medzníkom Druhý vatikánsky koncil (1962 - 1965), ktorý katolíckych krestanov vyzval na dialóg, vrátane dialógu s islamom. $\mathrm{Na}$ strane moslimov 
o dialóg usilujú predovšetkým intelektuálne elity, ako napríklad niektorí učenci z káhirskej univerzity Al-Azhar, považovanej za duchovné centrum sunnitského islamu. Signatári otvoreného listu Spoločné slovo (A Common Word between Us and You) - 138 prominentných predstavitelov islamského sveta - sa v roku 2007 obrátili na predstavitelov krestanských cirkví s výzvou hladania mieru, vzájomného porozumenia a spolupráce.

Iniciatívy prichádzajú zo strany politických a dynastických elít. Bývalý saudskoarabský král' Abdulláh, medzi iným, inicioval konferencie o dialógu v Mekke a Madride (2008) a bol spoluzakladatelom Medzinárodného centra pre medzináboženský a medzikultúrny dialóg, nesúceho jeho meno (KAICIID 2012). ${ }^{106}$

Ked’ Druhý vatikánsky koncil vyzval katolíckych krestanov na dialóg s moslimami, volil oceňujúce vyjadrenia vo vztahu $\mathrm{k}$ islamu. $\mathrm{V}$ tomto zmysle sa o islame vyslovuje vieroučná konštitúcia o Cirkvi Lumen Gentium: „Ale spasitelný plán zahŕña aj tých, ktori uznávajú Stvoritel'a, a medzi nimi predovšetkým moslimor, ktori turdia, že sa držia Abrabámovej viery a spolu s nami sa klañajú jedinému a milosrdnému Bohu, ktorý bude súdit' ludi v posledný deñ." 107

Podrobnejšie vyjadrenie $\mathrm{k}$ islamu obsahuje deklarácia Nostra aetate v článku 3:

„Cirkev sa súctou diva aj na moslimor, ktori sa klañajú jedinému, živému, jestvujúcemu, milosrdnému a všemohúcemu Bohu, Stvoritelovi neba i zeme, ktorý prehovoril k lud'om. Jeho ustanoveniam, a to aj skrytým, usilujú sa podrobit'z celébo

106 King Abdullah Bin Abdulaziz International Centre for Interreligious and Intercultural Dialogue.

107 Lumen Gentium, čl. 16. 
srdca, ako sa podriadil Bobu Abrahám, na ktorébo sa islamská viera rada odvoláva. Ježiša sice neuznávajú za Boha, ale si ho ctia ako proroka. Uctievajú si aj jeho panenskú matku Máriu a zavše ju aj nábožne vzývajú. Okrem toho očakávajú súdny deñ, ked'Bob dá odplatu všetkým zmŕtvychvstalým ludom. Popritom majú v úcte mravný život a uctievajú Boha najmä modlitbou, almužnou a pôstom.

Ak v priebehu vekov vznikli medzi krestanmi a moslimami mnohé rozbroje a nepriatel'stvá, tento svätý cirkevný snem vyzýva všetkých, aby zabudli na to, čo bolo, a pestovali úprimné vzájomné porozumenie a spoločne chránili a zvel'adovali u visetkých ludi sociálnu spravodlivost', mravné hodnoty, mier a slobodu."

\section{Hoci koncil len naznačil dialogickú politiku Kato-} líckej cirkvi k islamu a nerozpracoval celý rad tém, ktoré s ňou súvisia, predsa položil základy katolíckej pozície a načrtol stratégiu Katolíckej cirkvi vo vztahu k islamu.

V línii učenia koncilu rozvíja svoju činnost Pápežská rada pre medzináboženský dialóg, ktorá vznikla transformáciou (1989) Sekretariátu pre nekrestanov (1964 - 1989). V roku 1974 Sekretariát pre nekrestanov zriadil Komisiu pre islam a prebehlo viacero stretnutí na úrovni vysokej cirkevnej reprezentácie a medzinárodných islamských organizácií, ako sú Svetový islamský kongres a Najuyššia islamská rada. Od roku 1975 vydáva Pápežský inštitút arabistických stúdic a islamistiky v Ríme vedecký časopis Islamo-Christiana venovaný vztahom medzi krestanmi a moslimami. Mnohé impulzy pre krestansko-moslimský dialóg pochádzajú od pokoncilových pápežov - od Jána Pavla II., cez Benedikta XVI., po pápeža Františka.

Pochopitel'ne, novej politike Katolíckej cirkvi vo vztahu $\mathrm{k}$ islamu opät’ predchádzali desatročia príprav a iniciatív 
angažovaných jednotlivcov. Vel'kým priekopníkom krestansko-moslimského dialógu bol Charles de Foucauld (1858 - 1916), rodom francúzsky vikomt, spôsobom života pustovník a katolícky misionár v Alžírsku.

Charles de Foucauld stelesnil dialogický spôsob existencie bez toho, aby o dialógu vôbec hovoril - samotný spôsob jeho života bol bytostne dialogický. Tento dialogický charakter jeho života sa zrodil $v$ tom istom okamihu, $\mathrm{v}$ ktorom sa zrodilo jeho povolanie - Foucauld ho nazval "nazaretskýzivot".

Ked' v roku 1897 po vyše šiestich rokoch opustil chudobný vidiecky kláštor trapistov v Sýrii a odišiel do Palestíny, aby tam štyri roky slúžil a modlil sa v kláštore klarisiek v Nazarete, objavil to, čo dávno hladal. Tam, v Nazarete, našiel svoj spôsob života: nie je to len mníšsky život zameraný na kontempláciu, ale aj manuálna práca a ... ohlasovanie. Nie však ohlasovanie ako kázanie alebo učenie. Malý brat Karol, ako si začal po svojom obrátení hovorit,, stelesňuje novú formu ohlasovania - oblasovanie životom. Je to geniálne, je to evanjeliové, je to revolučné: vydávat svedectvo o Kristovi príkladom svojho života! Malý brat Karol takto „kriči evanjelium“ celým svojím životom. „Zo všetkých našich činov, z celého nášho života musi kričat, že patrime Ježišovi, “ píše. „Celá naša bytost musi byt živyým kázanim, odrazom Ježiša. " 108

Foucauld chcel vydat svedectvo o Kristovi predovšetkým moslimom. Aby mal prístup k Eucharistii, v roku 1901 prijal kňazskú vysviacku. Ešte v tom istom roku odišiel na Saharu a usadil sa v alžírskej oáze Beni-Abbés, nedaleko hraníc s Marokom. Dokonale sa prispôsobil

108 Foucauld 1998, s. 37. 
miestnej kultúre - obliekal sa ako Berber, stravoval sa ako Berber... a dalej rozvinul svoju víziu "nazaretskébo života" v spoločenstve. V liste Henrimu de Castries napísal: „Chcel by som založit'na pohraničnom územi s Marokom nie kläštor trapistor, nie klästor vel'ký a bohatý, ani nie nejakú polnohospodársku usadlost', ale akýsi drub malej skromnej pustovne, $v$ ktorej by mohlo żit niekolko chudobných mnichov z trochy ovocia a jačmeña získaného z práce vlastných rúk, v prísnej klauzúre, v pokáni a v orodovani Najsvätejšej oltárnej sviatosti, nevychádzajúc z klauzúry, nevenujúc sa kázaniu, ale poskytovaniu pohostinstva každému návšternikovi, či je dobrý, alebo zlý, priatel' alebo nepriatel," moslim alebo krestan. "109

Neskôr opíše svoju životnú víziu nasledovne: „Stat'sa všetkým pre všetkých, aby som ich všstkých odovzdal Ježišovi - mat pre nich dobrotu a bratskú lásku; slúziti im tak, ako je to možné; nadviazat's nimi srdečný vztab; byt pre nich nežným bratom, aby som ich pomaličky privádzal k Ježišovi, stelesňujúc Ježišovu miernost." ${ }^{\prime 110}$

Foucauld poznal, že jeho poslaním je stavat mosty. „Chcem,“ píše, „aby všetci obyvatelia, krestania, moslimovia, pohania, videli vo mne svojho brata, brata všetkých."

Týmto spôsobom - ako „brat všetkých“, ako stavitel” mostov - Charles de Foucauld vydáva svedectvo o svojom krestanskom živote: ohlasuje Krista dialogickým spôsobom existencie.

Foucauld predbehol svoju dobu. V časoch, ked' krestanské ohlasovanie splývalo s kázaním alebo vyučovaním krestanskej vierouky, malý brat Karol odhaluje antropo-

109 Ibid., s. 41.

110 Ibid., 57.

111 Lafon 2000, s. 56. 
logicky prvotnú a teologicky základnú formu ohlasovania - ohlasovanie spôsobom vlastnej existencie. Foucauld takto reprezentuje tézu, ktorú tu formulujeme nasledovne: fundamentálnou formou misie je dialogický spôsob existencie. A dialogický spôsob existencie potom konzekventne konštituuje dialogický étos - „základný morálny postoj jednotlivca, resp. spolocenstva, formovany principom vztahovosti ". 112

\subsection{Záver}

V nábožensky, kultúrne a etnicky pluralitnom prostredí súčasného sveta dialóg už nie je len jednou z možností vzájomnej interakcie, dnes je nevyhnutnostou. Tým, že predpokladá vztảh - interpersonálnu reláciu, ktorá môže prerást do priatelstva, ${ }^{113}$ autentický dialóg je alternatívou konfrontácie a konfliktu, ktoré charakterizovali vztahy medzi stúpencami rôznych náboženstiev po celé stáročia. Dialóg prináša šancu zastavit toto dedičstvo konfrontácie a konfliktu, ked'sa ponúka ako nástroj vzájomného zbližovania a facilitácie spoločného postupu - v spoločenskej, politickej, kultúrnej, morálnej i náboženskej oblasti.

V súčasnosti zaznievajú hlasy, že práve dialóg môže pomôct čelit kríze hodnôt, manifestujúcej sa v konzumnej mentalite, ktorá zasiahla celý globalizujúci sa svet. Rehabilitácia hodnôt na náboženskom základe je príležitost’ návratu do verejného priestoru veriacich rôznych viero-

112 Dojčár 2012, s. 65.

113 Johnston 1997, s. 47. 
vyznaní - či už sú to krest’ania, moslimovia, židia, alebo povedzme buddhisti. Veriaci rôznych vierovyznaní môžu súdobej „hyperkonzumnej civilizácii“"114 spoločne ponúknut” odkaz na hodnotovo ukotvený zmysel života, avšak pod podmienkou, že ho budú ohlasovat vlastným životom.

114 Lipovetsky 2007, s. 30. 


\section{Spirituálny dialóg}

V 20. storočí sa zrodila nová forma dialógu medzi stúpencami rôznych náboženstiev - spirituálny dialóg. Nejde pritom len o nejakú okrajovú podobu medzináboženského dialógu, o akúsi kuriozitu. Naopak, „dialóg duchoonej skúsenosti“" ${ }^{115}$ sa stal súčastou hlavného prúdu medzináboženského dialógu. V druhej polovici 20. storočia potom našiel svoj smerodajný inštitucionálny, doktrinálny aj personálny výraz.

Inštitucionálnym lidrom spirituálneho dialógu je v súčasnosti medzinárodné združenie katolíckych mníchov a mníšok Mnišsky medzináboženský dialóg (DIMMID). ${ }^{116}$ $\mathrm{Na}$ doktrinálnej rovine túto formu medzináboženského dialógu legitimizuje spoločný dokument Pápežskej rady pre medzináboženský dialóg a Kongregácie pre evanjelizáciu národov Dialóg a oblasovanie (1991), ktorý tak robí na základe učenia Druhého vatikánskeho koncilu.

Oboje má svoju genézu. Etablovaniu spirituálneho dialógu predchádzala usilovná práca jeho angažovaných

115 Dialóg a oblasovanie, čl. 41.

116 DIMMID je po organizačnej stránke komisiou Benediktinskej konfederácie, združujúcou katolíckych mníchov a mníšky, angažovaných v medzináboženskom dialógu, a spolupracujúcou s Pápežskou radou pre medzináboženský dialóg. V interview s autorom pre časopis $S p i-$ rituality Studies William Skudlarek, generálny sekretár DIMMID, predstavil niektoré $\mathrm{z}$ aktuálnych tém spirituálneho dialógu. Dojčár 2018, s. $30-31$. 
priekopníkov, mužov a žien, ktorí tento dialóg uvádzali do života predtým, ako dostal svoje inštitucionálne vyjadrenie a doktrinálne potvrdenie. Charles de Foucauld, Magdeleine Hutinová, svámí Abhišhiktanada (Henri Le Saux, OSB), Jules Monchanin, Francis Mahieu, OCSO, Bede Griffiths, OSB, Thomas Merton, OCSO, Jean-Marie Déchanet, OSB, Anthony de Mello, SJ, Hugo Makibi Enomiya-Lassalle, SJ, David Steindl-Rast, OSB, a d’alši z plejády pionierov duchovného dialógu vstúpili do prvej línie hladania jeho autentických foriem a vytrvali v nej napriek početným tažkostiam, prekážkam a pochybnostiam. $\mathrm{Na}$ ich odkaz nadväzujú tí, ktorí prichádzajú po nich.

A aký je odkaz pionierov spirituálneho dialógu? Hlavné rysy dialógu duchovnej skúsenosti dalej vymedzíme a opíseme na základe životného svedectva jedného z jeho prominentných predstavitelov, jezuitu nemeckého pôvodu, katolíckeho misionára v Japonsku, Huga Makibi Enomiya-Lassalla. Našu prípadovú štúdiu metodologicky zasadíme do rámca hermeneutickej religionistiky.

Lassallovo poňatie spirituálneho dialógu nemožno oddelit od jeho katolíckeho kontextu. Do problematiky nás preto uvedie teologická kontextualizácia Lassallovho dialogického odkazu v nasledujúcej podkapitole, na ktorú dalej nadviažeme jeho detailnou charakteristikou.

\subsection{Doktrinálne ukotvenie spirituálneho dialógu v učení Magistéria}

Kontakty medzi stúpencami rôznych náboženských a duchovných tradícií ukázali, že „ani tá najsvedomitejšia 
práca s textami, resp. pojmová analýza nemôže stačit', stále zostáva potrebné meditativne zbližovanie, teda spirituálna prax “ ${ }^{117}$ Nečudo, že prirodzený vývoj dal vzniknút viacerým formám medzináboženského dialógu. Spoločný dokument Pápežskej rady pre medzináboženský dialóg a Kongregácie pre evanjelizáciu národov Dialóg a oblasovanie ich rozlišuje štyri: dialóg života, dialóg činnosti, dialóg teologickej výmeny a dialóg duchoonej skúsenosti. ${ }^{118}$ Medzináboženský dialóg zdaleka nemá len podobu odborného dialógu teologickej diskusie (teologický dialóg), či koinonického dialógu spoločenskej angažovanosti, alebo každodenného dialógu života v nábožensky pluralitnom prostredí, ale aj rýdzo náboženskú podobu dialógu spoločenstva v modlitbe ${ }^{119}$ a dialógu duchornej skuisenosti (spirituálny dialóg).

Významným priekopníkom spirituálneho dialógu bol jezuita Hugo Makibi Enomiya-Lassalle (1898 - 1990). Hugo Lassalle v Japonsku, rovnako ako Henri Le Saux, Jules Monchanin, Francis Mahieu a Bede Griffiths v Indii, predišli Druhý vatikánsky koncil o dlhé roky až desat'ročia a predznamenali niektoré $\mathrm{z}$ jeho učení. Páter Lassalle príkladným spôsobom uskutočnil výzvu ostatného cirkevného snemu „uznat', chránit' a zveladovat duchovné, mrav-

117 Wehr 1999, s. 123.

118 Dialóg a oblasovanie, čl. 41.

119 Svetové dni modlitieb za mier v Assisi $(1986,2002,2011)$ sú príkladom dialógu spoločenstva $\mathrm{v}$ modlitbe. $\mathrm{Na}$ medzináboženských modlitbových zhromaždeniach sa veriaci schádzajú, aby sa spoločne modlili, pričom každé náboženské spoločenstvo sa modlí svojím spôsobom na spoločný úmysel, a zároveň je zúčastnene prítomné pri modlitbe partnerov v dialógu. $V$ spirituálnom dialógu účastníci navzájom zdielajú svoje osobné skúsenosti z vlastnej duchovnej praxe, či už ide o askézu, modlitbu, rozjímanie, alebo kontempláciu. 
né a spoločensko-kultúrne hodnoty" ${ }^{120}$ ktoré sa nachádzajú $\mathrm{v}$ iných náboženských tradíciách, $\mathrm{v}$ jeho prípade predovšetkým v buddhizme.

\subsection{Hlavné rysy spirituálneho dialógu v podaní Huga M. Enomiya-Lassalleho}

Vo svojom misijnom pôsobení v Japonsku páter Lassalle nadviazal na tradičnú jezuitskú misijnú stratégiu akomodácie. Akomodácia predstavuje úsilie ponúknut krestanské posolstvo vo forme zrozumitelnej a prijatelnej adresátom tohto posolstva. Historickým príkladom úspešnej akomodácie je pôsobenie talianskeho jezuitu Roberta de Nobili $(1577$ - 1656) v Indii. Podobne postupoval aj Hugo Lassalle $\mathrm{v}$ Japonsku, kde pôsobil temer po celý svoj reholný život. V Hirošime prežil výbuch atómovej bomby (1945), bol vážne zranený a s nasadením vlastného života pomáhal postihnutým spoločne s Pedrom Arrupem, neskorším generálnym predstaveným Spoločnosti Ježišovej. Jeho obetavost' si Japonci neskôr uctili ocenením čestnýobčan Hirošimy (1968) a Lassalle, na znak svojho spojenia s japonským národom, prijal japonské občianstvo (1948) a japonské meno Makibi Enomiya.

Počas svojho dlhého pôsobenia v Japonsku Hugo Lassalle pochopil, ako upozorňuje Tomáš Halík, že „ak si má ako krestan a Európan nájst'cestu k srdcu Japoncov, musis nimi zdielat' ich duchoonú skúsenost ${ }^{\prime \prime}{ }^{121} \mathrm{~V}$ súlade $s$ jezuitskou

\section{Nostra aetate, čl. 2.}

121 Halík „Predhovor“ in Enomiya-Lassalle 1995, s. 5. 
tradíciou akomodácie sa preto zaujímal nielen o kultúru, ale aj o náboženstvá a spirituality hostitel'skej krajiny. Od roku 1943 sa venoval štúdiu a praxi zenu, ako duchovného jadra japonského buddhizmu a jedného zo základných civilizačných zdrojov japonskej civilizácie. ${ }^{122}$ Akomodácia je prvý znak spirituálneho dialógu, ktorý je charakteristický pre pôsobenie Huga Makibi Enomiya-Lassalla.

Páter Lassalle bol zrejme prvý katolícky kňaz v dejinách, ktorý praktizoval zen pod priamym vedením japonského zenového majstra. Bol tiež prvým kňazom vôbec, ktorý získal autorizáciu vyučovat’ zen ako kompetentný znalec zenu, a napokon, bol prvým autorom, ktorý písal o uplatnení zenu v katolíckej spiritualite na základe vlastnej skúsenosti a nadobudnutej kvalifikácie.

Autorizáciu vyučovat zen Lassallovi udelil róši Kóun Jamada v roku 1978. ${ }^{123}$ Páter Lassalle následne vyučoval zen prevažne v Japonsku a Európe až do svojej smrti v roku 1990. Súčasne sa usiloval premysliet’ a opísat’ vztah medzi zenovou a katolíckou spiritualitou na základe vlastnej desatročia trvajúcej duchovnej praxe a skúsenosti s obomi tradíciami spirituality. Takto sa mu podarilo jedinečným spôsobom zachytit’ styčné body, ale aj rozdiely medzi týmito dvomi tradíciami spirituality, ktoré predpokladajú skúsenostné poznanie oboch.

122 Zen predstavuje duchovné jadro japonskej civilizácie a manifestuje sa v japonskom umení a jeho svojráznych kultúrnych formách, ako sú umenie lukostrel'by (kjudó, „cesta luku“), čajového obradu (čadó, „cesta čaju“), ikebany (kadó, „cesta kvetov“), džuda (judó, ,jemná cesta“) a pod.

123 Róši Kóun Jamada bol nástupcom zenového majstra Hakuunu Rjóko Jasutami, ktorý v roku 1954 založil školu Sanbó Kjódan v línii japonskej zen-buddhistickej tradície Sótó, spojenej s prvkami tradície Rinzai. 
V dialogických aktivitách Huga Lassalla môžeme rozlíšit dve roviny - praktickú rovinu dialogickej interakcie a teoretickú rovinu dialogickej reflexie. Prvej rovine zodpovedá Lassallova koncepcia zenu pre krestanov, druhej rovine zas celý rad teologických otázok spojených s touto koncepciou, medzi iným, téza o univerzalite transcendentnej „skúsenosti“.

\section{Druhým znakom dialógu duchovnej skúsenosti v podaní pátra Lassalleho je takto zen pre krestanov.}

Hugo Makibi Enomiya-Lassalle rozlišuje tri konštitutívne zložky zenovej formy kontemplácie, známej skôr pod jej japonským názvom zazen. ${ }^{124}$ Sú to (1) telesná pozícia, (2) dýchanie a (3) duševný postoj. ${ }^{125}$

$\mathrm{V}$ ich formulácii sa odráža východná mentalita: nejde tu len o poukaz na techniku - technický aspekt praxe, ako by sa mohlo na prvý pohl'ad zdat'-, skôr ide o zmysel pre obraz a konkrétno, ktorý je vlastný východnému človeku, $\mathrm{v}$ protiklade $\mathrm{k}$ západnému pojmovému a abstraktnému mysleniu karteziánskeho typu. Tri zložky zazenu sú obrazy, ktoré majú symbolický význam, pričom súčasne nestrácajú svoj konkrétny rozmer.

1) Standardnou pozíciou zazenu je lotosová pozícia, resp. polovičná lotosová pozícia - meditačná ásana rozšírená po celej Ázii.

Pozícia má symbolický význam: naznačuje, že vedomie sa „usadí" na tele, takpovediac rozprestrie sa po tele - najprv po nohách, presnejšie po povrchu nôh, neskôr po celom tele, akoby plášṫ či závoj, ktorý ho jemne prikryje.

124 Japonský výraz zen pochádza zo skt. dhjána, ktorý v klasickej Pataňdžaliho joga-daršana predstavuje siedmy stupeň „osemdielnej“ (skt. aštanga) jogy. Výraz za znamená „sed“ - zazen je teda „zen v sede“, v prenesenom zmysle meditácia v sede.

125 Enomiya-Lassalle 1995, s. 32 - 34. 
2) Dýchanie počas zazenu je hlboké, uvolnené a prirodzené - nekombinuje sa s technikami pránajámy, ako $\mathrm{v}$ niektorých školách indickej jogy.

Dýchanie má opät symbolický význam: naznačuje, že vedomie sa „usadi“" na dychovom cykle, rozprestrie sa na nádych, výdych a medzidych (perióda medzi dychovými cyklami). Dychový cyklus sa v dôsledku spojenia s pozornostou vedomia zjemňuje a postupne sa prejavuje ako „vitálna sila“ prestupujúca telom - „dych života“ $(\mathrm{Gn} 2,7)$.

3) Duševný postoj je najdôležitejšou zložkou zazenu - bez neho zazen vôbec nenastane. ${ }^{126}$ Páter Lassalle ho opisuje tradičným výrazom „bez pojmov a bez myšlienok“, ale možno ho charakterizovat aj ako intenzívnu jasnost' pozornosti, luciditu vedomia, ktoré sa nespája s ničím, čo sa objavuje v jeho zornom poli, ako ked divák bedlivo sleduje predstavenie bez toho, aby sa strácal v prežívaní jednotlivých scén: pozoruje ich, ale nenechá sa nimi strhnút do zabudnutia, že je pozorovatel'om predstavenia. , $J a$ sa musi stat pasionym, t. j. receptívnym," upresňuje Hugo Lassalle, „musi sa otvorit, aj ked'sa navonok uzatvárame... Inými slovami: je treba preniknút do blbšich vrstiev vedomia. Ale to sa nedá vynuitit,' musi to nastat'samo." ${ }^{127}$

Duševný postoj má symbolický význam: naznačuje rozlíšenie pozornosti vedomia od pozorovaných predmetov - fyzikálnych objektov, organických procesov i psychomentálnych procesov a obsahov. $V$ dôsledku tohto rozlíšenia sa pozornost' obracia sama na seba priamo úmerne tomu, ako sa „odpája“ od pozorovania objektov, avšak pod podmienkou, že je zachovaná intenzívna bdelost'. Týmto

126 Kaisen 2018, s. $30-31$.

127 Enomiya-Lassalle 1995, s. 34. 
spôsobom sa pozornost' vedomia vracia spät do vedomia, z ktorého pochádza a uvedomuje sa ako vedomie - slobodný, nespútaný duch.

Obrátit pozornost' na pozornost' znamená uvedomit' sa ako subjekt všetkého diania a prežívania. Inými slovami, znamená to „len byt" (existencia), nie „byt týmto“ (esencia). Výsledkom je odkrytie primordiálnej, teda nepodmienenej subjektivity (Self) v kontrapozícii k odvodenej, podmienenej subjektivite (Ego). Jeden $\mathrm{z}$ počiatočných stupňov vhladu do primordiálnej subjektivity zen opisuje prostredníctvom metafory „zrkadla“, ako ilustruje zenová báseň, na ktorú odkazuje páter Lassalle: ${ }^{128}$

\section{Toto telo je strom bódhi, duša je ako cisté zrkadlo, dbaj, nech je vždy cisté a nenechaj na ňom usadzovat prach.}

Zmyslom zazenu je oslobodit pozornost' vedomia z jej pohltenia objektom - zmyslovým i psychomentálnym prekrývajúcim samotný „priestor“ vedomia. Dynamiku zastretia "pola“" vedomia objektami situovanými v tomto „poli“" naznačuje tradičná buddhistická metafora opice v dome so šiestimi oknami. Opica skáče od okna k oknu, je neustále $\mathrm{v}$ pohybe, vyzerá $\mathrm{z}$ okien a sleduje, čo sa deje vonku.

Opica tu symbolizuje vedomie, resp. jeho prejav navonok, teda pozornost', filozoficky intencionalitu. Okná symbolizujú zmysly. Buddhistická psychológia rozlišuje šest' zmyslov - $\mathrm{k}$ piatim zmyslom pridáva ešte mysel.

128 Ibid., s. 29. 
Opica skáče od okna k oknu - to znamená, že pozornost' preskakuje z objektu na objekt podla toho, aký dojem ju strhne v danej chvíli najviac; jej predmet sa teda neustále mení - raz sú to zmyslové vnemy, inokedy psychomentálne objekty. Výsledkom je nejasné rozptýlené vedomie, teda vedomie, ktoré sa necháva unášat dojmami a stráca sa $\mathrm{v}$ prežívaní. $V$ buddhizme sa obrazne označuje termínom „opičie vedomie“. Jeho sprievodným znakom je nepokoj.

Opica o sebe nevie, pretože neustále hl'adí von niektorým z okien. Ak by sa však upokojila, mohla by poznávat samu seba. Inými slovami, kým je pozornost' obrátená ad extra, dovtedy je vedomie absorbované v neustále sa meniacich predmetoch pozornosti, akonáhle sa však „usadi“ na určitom predmete pozornosti, upokojí sa a môže poznávat' samé seba.

To je princíp jogy, sformulovaný legendárnym $\mathrm{Pa}$ taňdžalim $\mathrm{v}$ Joga sútrach, klasickom diele joga-daršany, jedného zo šiestich normatívnych filozofických systémov Indie: "Jogahčittavrttinirodhab" - "Joga je zastavenie premien vedomia“, ${ }^{129}$ a dalej rozvinutý takto: „Potom vedomie spočíva samo v sebe [pozn. poznáva samé seba]. “130

Aby sa obrat pozornosti mohol uskutočnit', musia nastat vhodné podmienky. V buddhizme sú dvojakého druhu: morálne a koncentračné. Prvá kategória sa týka spôsobu života a obvykle, najmä v klasickom južnom buddhizme (tradícia theraváda), zahŕňa mníšsku disciplínu. ${ }^{131}$ Druhá

129 Patanjali, Yoga sutras I, 2 in Woods 1998.

130 Patanjali, Yoga sutras I, 3 in Ibid.

131 Podmienkou zazenu je tak isto mravná kvalifikácia, založená na zvnútornených hodnotách a rozvinutých postojoch. Pedro Arrupe (1992, s. 167) zaznamenal nasledovný morálny imperatív v rozhovore s nemenovaným zen-buddhistickým mníchom: je potrebné 
kategória sa týka vytvárania podmienok pre stiahnutie pozornosti ad intra za pomoci sústredenia.

Japonský zen rozvíja sústredenie predovšetkým prostredníctvom troch základných techník: (1) koncentrácie na dýchanie, (2) koncentrácie na kóan a (3) „len sedenia“. Prvé dve sa uplatňujú prevažne v doktrinálnej škole Rinzai, zatial čo prvá a tretia technika sú vlastné škole Sótó, druhej vel'kej škole japonského zenového buddhizmu.

1) Koncentrácia na dýchanie spočíva, $v$ Lassalleho interpretácii, $\mathrm{v}$ počítaní dychových cyklov od 1 po 10 , pričom nádych sa počíta nepárnymi číslami, výdych párnymi. Počítanie má pomôct' redukovat psychomentálny tok a umožnit pozornosti „odpojit sa“ od obvyklej väzby naň, aby mohla preniknút do hlbších vrstiev vedomia, ${ }^{132}$ ktoré krestanská tradícia, tvrdí Lassalle, označuje pojmom „základ duše e. .133 Počítanie len nádychov má podla tradície pomôct' obmedzit roztržitost', počítanie len výdychov má pomôct' prekonat' ospalost. ${ }^{134} \mathrm{~S}$ pokrokom v sústredení počítanie ustáva a nahrádza ho sústredené pozorovanie dychového cyklu tak, ako samovolne plynie.

2) Kóan je výraz čínskeho pôvodu a doslovne znamená „verejné oznámenie“. Avšak v zene má iný význam: je to paradoxná výpoved', logicky neriešitel’ná „hádanka“, ktorej zmyslom je transcendovat diskurzívne myslenie. Škola Rinzai uchováva okolo 1700 kóanov, zväčša vo forme roz-

„zachovávat' isté pravidlá správneho správania... neustále strážit' brány svojich piatich zmyslov... vyvarovat' sa čo i najmenšej nedbanlivosti a pestovat'stálu túžbu konat' dobré skutky“.

132 Enomiya-Lassalle 1995, s. 35.

133 Ibid., s. 53.

134 Ibid., s. 35. 
hovorov medzi učitelom a žiakom. Škola Sótó kóany nepouživa, kladie dôraz na "len sedenie“ (jap. šikantaza).

3) V striktnom zmysle slova „len sedenie“ nie je technika, je to samotná podstata zenu. Žiak „len“ sedí, dýcha a udržiava správny duševný postoj bez toho, aby použival akékolvek dalšie pomocné prostriedky. Nejde však vôbec iba o sedenie predpísaným spôsobom. Ked’ ho opisuje, páter Lassalle cituje zenového majstra Harada Sogaku: „Zazen je pocit taký silný, ako keby sa zafu [pozn. poduška], na ktorej sedime, stala zemegulou a vesmir vyplñal spodnú cast' tela." ${ }^{135}$

$\mathrm{V}$ rozhovore $\mathrm{s}$ nemenovaným japonským mníchom Pedro Arrupe zaznamenal takýto opis zazenu: „Ducha treba dokonale vypnút', nemysliet' na nič... Praktizujúci sa usilujú na nič nemysliet', alebo lepšsie povedané, nič nemysliet' a o nič neusilovat. Je to stav... bez uisilia, ktorý trvá najmenej hodinu, alebo hodinu a pol. Sú dni, ked'sme v zazene až osem hodin." "136

Popri tradičnej metóde a súbore techník japonský zen predpokladá intervenciu učitela, zenového majstra. Zen, rovnako ako všetky „umenia“ od zenu odvodené, sa totiž odovzdáva zasvätením, nie poučením, presnejšie prenosom - transmisiou $z$ učitela na žiaka. ${ }^{137}$ Učitel' odovzdáva inštrukcie a odpovedá na otázky k praxi či už počas zazenu, ako v prípade školy Sótó (jap. dokusan, „íst individuálne“), alebo aj súkromne v priebehu dňa (jap. naisan, „íst' súkromne") ako v prípade školy Rinzai, ale súčasne a predovšetkým samovolne „prenáša“ na žiaka stav, ktorý je mu po „prebudení“ (jap. satori) vlastný, a ktorý jedine mu prepožičiava status majstra zenu.

135 Ibid., s. 39.

136 Arrupe 1992, s. 163.

137 Enomiya-Lassalle 1995, s. 41. 
Žiak si vyberá majstra sám. Pokial vstupuje do kláštora, jeho výber sa zhoduje $s$ výberom kláštora. Platí však pravidlo, že majster sa nemení. Ak by predsa len v odôvodnených prípadoch došlo $\mathrm{k}$ zmene majstra, žiak musí zanechat' všetko, čo sa naučil od pôvodného majstra. ${ }^{138}$

A čo je výsledkom zazenu? Zanmai - kontemplatívne ponorenie, enstáza. Zanmai je japonská transkripcia sanskritského výrazu samádhi. Význam oboch termínov je totožný, aj ked' na rozdiel od indických a tibetských tradícií jogy, japonský zen nerozlišuje stupne samádhi a finálnu modalitu samádhi označuje špecifickým výrazom - satori.

Konečným cielom zenu je teda satori (jap. „porozumenie“, „vzhlad“). Stavu satori obvykle predchádza kenšó (jap. ken, „nazrenie“, šhó, „podstaty“). Satori je transcendentná „skúsenost“, ktorá je trvalá, kenšó sú „záblesky“ tejto „kkúsenosti“, ktoré sú dočasné - objavujú sa a miznú.

Satori „sa zvyčajne opisuje ako pochopenie podstaty vecí,“ pokračuje vo svojom rozhovore s japonským mníchom Pedro Arrupe, „[v] skutočnosti sa nedá opisat.' Len ten, kto ho dosiahne, vie, čo znamená." Jeho duchovným a morálnym ovocím je „duševná sloboda, úplné sebaovládnutie... Človek prestane byt' otrokom vonkajšich okolnosti a vnútorných žiadosti a stane sa pánom nad sebou samým..." ${ }^{139}$

Ako transcendentná „skúsenost", satori uniká pojmovému uchopeniu - nie je to však ,skúsenost" kontra-racionálna, je supra-konceptuálna. Textové tradície čínskych, japonských a kórejských škôl zenu sa zásadne vyhýbajú opisu satori. Rovnako ako tradície krestanskej mystiky, volia apofatický jazyk a zdôrazňujú primát skúsenostného

138 Ibid., s. 44.

139 Arrupe 1992, s. 163. 
poznania: transcendentnú „skúsenost' “ nemožno adekvátne sprostredkovat pojmom a vyjadrit’ termínom - transcendentnú „skúsenost' “ treba žit'. Ako mystické, tak aj zenové tradície sa spoločne vztahujú k experimentálnemu, skúsenostnému, žitému poznaniu v protiklade k diskurzívnemu, racionálnemu, pojmovému poznaniu.

A predsa, aj prísne apofatické školy krestanskej mystiky a zenového buddhizmu tu a tam zaznamenávajú opis transcendentnej „skúsenosti“. O opise satori zenového majstra Imakita Kósenu referuje páter Lassalle: „Jednej noci som bol ponorený do meditácie, a tu som sa náble dostal do celkom nečakaného stavu. Bol som ako mŕtvy. Všetko akoby prestalo. Nebolo žiadne predtým a žiadne potom. Stratil sa predmet mojej meditácie aj moje vlastné Ja. Jediné, co som si uvedomoval bolo, že základ môjho Ja je celkom zjednotený a naplnený všetkým, co je hore, dole a dookola. Žiarilo vo mne nekonečné svetlo. Po chvili som zase prišiel k sebe ako niekto, kto vstal z mŕtuych. " 140

Podla Huga Lassalla v zene ide o transcendujúci proces, ktorý „postupuje opačne, ako diskurzínne myslenie. Spätne bežným spôsobom pred začiatok obvyklébo myslenia. Teraz chápeme, že ak chceme dôjst' $k$ skúsenosti vlastnej existencie, $k$ satori, diskurzione myslenie musi byt' zastavené... Človek musi odumriet' všetkému starému, aby mohol vzniknút' nový život. Učenie o smrti a zmŕtoychustani je známe aj v buddbizme, zvlášt'v zene." 141

Inak povedané, satori predstavuje experimentálne poznanie "pravébo Ja“, čiže „najblbšieho Ja v protiklade k em-

140 Enomiya-Lassalle 1995, s. 66.

141 Ibid., s. 68. 
pirickému Ja“"142 - to znamená, neskonštruovaného „jadra osobnosti“ (Self) v protiklade k sebaobrazu skonštruovanému v priebehu ontogenézy (Ego). „Je to skúsenost' existencie," ktorú Lassalle nazýva tiež „bezprostredným vnimanim pravého Ja“: „Človek skúsenostne poznáva nerozdelené absolútne bytie. " ${ }^{43}$

Dlhoročné dôkladné skúmanie zenovej a krestanskej spirituality vedie pátra Lassalleho k záveru, že satori a hlboké mystické skúsenosti krestanských mystikov sú ako transcendentné „"kúsenosti“ " „skuisenostami tohoto bytia“ ${ }^{144}$ Pojmové vyjadrenia „skúsenosti“ absolútneho bytia sa však môžu líši od tradície $\mathrm{k}$ tradícii. ${ }^{145}$ Touto interpretáciou sa Hugo Makibi Enomiya-Lassalle hlási k univerzalistickej téze, ktorú možno v skratke sformulovat nasledovne: jedna „skúsenost" "transcendentnébo typu, mnoho interpretácii. Slovami amerického postkonštruktivistického filozofa Roberta K. C. Formana: ak interpretácia podstatne neformuje transcendentnú „skúsenost' “, tak mystika je „transkultúrne homogénna" a vyznačuje sa niekolkými základnými črtami. ${ }^{146}$ Univerzalistická téza je takto tretím znakom dialógu duchovnej skúsenosti v podaní Huga Lassalleho.

Z univerzálnej povahy transcendentnej „skúsenosti“ vyplýva, že buddhista síce v satori "preživa najblbšie Ja, zakuisa ho však ako absolútne bytie", pretože buddhistické doktríny popierajú existenciu podmieneného Ja (pálí anattá, skt. anátman), zatial' čo krestan alebo človek, kto-

\footnotetext{
142 Ibid., s. 69.

143 Ibid., s. 70.

144 Ibid., s. 70.

145 Ibid., s. 70.

146 Forman „Introduction: Mysticism, Constructivism and Forgetting“ in Forman 1990, s. 3 - 4.
} 
rý verí v osobného Boha (monoteista) "preživa to isté Ja“, ale poznáva $\mathrm{v}$ ňom Boha, pretože monoteistická viera je založená na personálnom vztahu človeka a Boha. ${ }^{147} \mathrm{Z}$ fenomenálneho hladiska, čiže z hladiska prežívania, však "[o]baja, buddhista aj krestán (monoteista), sú vo svojej skúsenosti oslobodeni od strachu a pochybnosti a naplneni najblbšim pokojom a najuyššou radostou." 148

Lassalle d’alej rozvíja svoju tézu o univerzálnej povahe transcendentnej „skúsenosti“ a pluralite jej interpretácií na základe rozlíšenia medzi predmetnou a nepredmetnou meditáciou. Predmetná meditácia je rozjimanie tak, ako je doložené v dejinách katolíckej spirituality. Témou rozjímania sú najčastejšie biblické motívy, jeho nástrojom sú duševné schopnosti - kognitívne (zmyslové vnímanie, pamät', predstavivost' a pod.), afektívne (citové prežívanie) a konatívne (zamerané na realizáciu cielov rozjímania prostredníctvom uplatnenia vôle).

Nepredmetná meditácia sa od predmetnej líši absenciou predmetu rozjímania. Kým prvá sa považuje za typicky krest’anskú, druhá má byt typicky zenová. To je však simplifikácia, tvrdí Lassalle, pretože v Katolíckej cirkvi neprerušene plynie „mystický prúd “, ktorému je vlastná nepredmetná meditácia, ${ }^{149} \mathrm{v}$ tradíciách krestanskej spirituality označovaná skôr ako kontemplácia. Jej nositel'mi sú kontemplatívne rehole a krestanskí učitelia kontemplácie.

Navyše, v kontemplatívnych spiritualitách katolíckej proveniencie má rozjímanie presne vymedzené miesto - je prípravou na kontempláciu (nepredmetná meditácia). Túto

147 Enomiya-Lassalle 1995, s. 70 - 71.

148 Ibid., s. 71.

149 Ibid., s. 78. 
myšlienku Lassalle ilustruje odkazom na učenie o „temnej noci duše" a "temnom nazerani " 150 smerodajného učitela kontemplácie v katolíckej tradícii, sv. Jána z Kríža, a konštatuje, že zen smeruje $\mathrm{k}$ tomu istému cielu, len „[p]oužíva $k$ tomu prirodzené sily človeka, určitú telesnú poziciu, dýchanie a ustávanie myslenia. Ak je treba, tak ako pomôcku aj sústredenie na dych alebo kóany. To sú prirodzené prostriedky, ktoré sú dostupné každému a nie sú viazané na náboženskú vieru, ani na buddhizmus. Môže ich teda použivat' aj krestan," uzatvára páter Lassalle, „bez toho, aby sa dostal do rozporu so svojim náboženským presveď̌enim". ${ }^{151}$

V uvedenom zmysle Lassalle začal so súhlasom svojich reholných predstavených vyučovat' zen krestanov najprv v Japonsku, neskôr v Európe. Na jeho odkaz naviazali jeho priami žiaci i další nasledovníci - írsky jezuita William Johnston, americký jezuita Robert Kennedy, švajčiarsky jezuita Niklaus Brantschen a iní. Na Slovensku to bol predovšetkým Mons. Jozef Vrablec svojou knihou Pozvanie $k$ zenovej meditácii (1992).

Hlavné apoštolské dielo švajčiarskej provincie Spoločnosti Ježišovej nesie na počest' Huga Lassalleho vo svojom názve jeho meno: Lassalle Haus. Strom života pokorného, skromného a osudom skúšaného pátra Lassalleho vydal bohaté ovocie.

150 Ibid., s. 81.

151 Ibid., s. 81. 


\subsection{Diskusia k univerzálnej povahe transcendentnej „skúsenosti“}

Hugo M. Enomiya-Lassalle odkazuje na mystiku „temnej noci“ sv. Jána z Kríža (1542 - 1591), ked' uvažuje o fenoméne nepredmetnej meditácie, inými slovami klasickej kontemplácie v krestanskej spiritualite. Rovnako by mohol odkazovat na dalších klasikov krestanskej mystiky - na majstra Eckharta (1260 - 1328) či na anonymného autora Oblaku nevedenia (14. storočie). Všetci reprezentujú takzvanú „mystiku zabúdania“.

"Zabudnutie“ či „zanechanie všetkého“ je, podla neznámeho anglického autora Oblaku nevedenia, podmienkou kontemplácie sine qua non. ${ }^{152} \mathrm{~V}$ tomto klasickom diele krestanskej mystickej spirituality sa však pojem zabudnutie použiva vo viacerých významoch. Vo vztahu $\mathrm{k}$ praxi kontemplácie, kontemplujúci musí opustit všetko, čo sa objavuje $\mathrm{v}$ zornom poli jeho vedomia. $V$ kontemplácii "treba úplne zabudnút na všetko okrem Boha ${ }^{\prime 153}$ a v tejto "temnote" vytrvat', nenechat' sa strhnút psychomentálnym dianím, ale udržat ho v „oblaku nevedenia“, postaveného medzi človeka a Boha, a v „oblaku zabudnutia“, ktorý stojí medzi človekom a svetom. ${ }^{154}$

152 Dojčár 2008, s. $51-57$.

153 The Cloud of Unknowing, s. 92.

154 „Tak, ako je tento oblak nevedenia nad tebou, medzi tebou a Bohom, musís tiež položit’oblak zabudnutia medzi seba a všetko stvorenie." (Ibid., s. 66). Synonymom pre zabudnutie je uzobranie (z gr. legein, „uzoberat' “). Vo väzbe na európsku filozofickú tradíciu slovenský teológ Radovan Šol- 
Vo vztahu k cielu kontemplácie, zabudnutie označuje stav, v ktorom ustáva psychomentálne dianie. Tento stav „tichej“, „čistej“ či „prázdnej mysle“ Robert K. C. Forman vztahuje k transcendentnej „skúsenosti“, ktorú konceptualizuje ako „udalost' cistého vedomia“. ${ }^{155}$

„Udalost'íistého vedomia“ (angl. „pure consciousness event", PCE) predstavuje ústrednú kategóriu postkonštruktivistického diskurzu filozofie náboženstva a označuje stav „bdelého, ale bezobsažného (neintencionálneho) vedomia“. ${ }^{156}$ Práve neintencionalitou, teda tým, že „subjekt je bdelý, vedomý, ale bez objektu či obsahu vedomia“, ${ }^{157}$ sa má udalost' čistého vedomia odlišovat od „bežnej“ skúsenosti, ktorá je svojím zameraním na predmet (intencionalita) vždy skúsenostou "niečoho“.

Naše predchádzajúce skúmanie ukazuje, že kontempláciu v mystike Oblaku nevedenia charakterizuje neintencionalita - finálna „skúsenost' “ je stavom bdelého, ale bezobsažného vedomia. ${ }^{158}$ Inými slovami, Oblak nevedenia uvádza na cestu spojenia s vždy väčším Bohom (Deus semper maior) - jeho cielom je „zjednotenie s Bohom v duchu, láske a v súlade vôle“159. Metóda Oblaku nevedenia "spočiva $\checkmark$ jednoduchom rozpoznani a slepom [pozn. bezprostredno-skúsenostnom] prijati vlastnej existencie. "“60 K spoje-

tés považuje uzobranie za cestu k spočinutiu vo vlastnom bytí. (Šoltés 2021, s. 114 - 115).

155 Forman „Introduction: Mysticism, Constructivism and Forgetting“ in Forman 1990, s. 8.

156 Ibid., s. 8.

157 Bernhardt „Are Pure Consciousness Events Unmediated?“ in Forman 1990, s. 220.

158 Dojčár 2013, s. 5-10.

159 The Cloud of Unknowing, kap. 67, s. 141.

160 The Epistle of Privy Counsel in The Cloud of Unknowing, kap. 1, s. 161. 
niu s Bohom (lat. unio mystica) dochádza skrze vedomie vlastnej existencie, pretože ono je „stopou“ Boha, ktorú v človeku zanecháva jeho Stvoritel.

Anglický mystik podáva svoj návod ku kontemplácii na základe tradičného metafyzického rozlišenia medzi bytím (lat. esse, tiež actus essendi - akt bytia) a súcnom (lat. ens) s jeho bytnostou (lat. essentia, quidditas - to, čo robí súcno súcnom). $V$ terminológii klasickej metafyziky súcna sú jedno z hladiska existencie - tým, že sú, a mnohé $\mathrm{z}$ hladiska esencie - tým, čo sú.

Vychádzajúc z tohto rozlíšenia, stredoveký mystik obracia našu pozornost $\mathrm{k}$ faktu našej existencie, $\mathrm{k}$ prvotnému apodiktickému poznaniu, ktoré možno verbalizovat ako „som a viem, že som“ (lat. esse). Táto „stopa“ bytia vedie kontemplujúceho ako zlatá nit zo sveta súcna do sveta bytia - od „pobytu“ k ,existencii“. ${ }^{161}$

$\mathrm{V}$ dynamike sebatranscendencie dochádza $\mathrm{k}$ zrušeniu všetkých foriem identifikácie medzi súcnom (lat. ens) a bytim (lat. esse) - odvodeným (Ego) a primordiálnym (Self) subjektom, aby sebatranscendencia nakoniec dosiahla svoj kulminačný bod v sebaodovzdaní, ked' sa duša "v láske umenšuje a Boha vyvyšuje ako všetko vo všetkom “. ${ }^{162}$

Opis „mystického spojenia“ (lat. unio mystica) sa vymyká možnostiam jazyka, prekračuje hranice ludského chápania a hovorenia. Aj ked' ho opisuje ako dokonalost' a blaženost', autor Oblaku vie rovnako, ako to vedia zenoví majstri, že každé tvrdenie o transcendentnej „skúsenosti“ je napokon neadekvátne. ${ }^{163}$

161 Dojčár 2017, s. 40 - 49.

162 The Epistle of Privy Counsel in The Cloud of Unknowing, kap. 6, s. 178.

163 The Cloud of Unknowing, kap. 26. 


\subsection{Záver}

Tri slová majú charakterizovat postoj krestana k nekrestanským náboženstvám podla deklarácie Nostra aetate - „uznat', chránit' a zveladovat' duchovné, mravné a spoločensko-kultúrne hodnoty, ktoré sa v nich nachádzajú “. ${ }^{164}$ Hugo Makibi Enomiya-Lassalle prijal za svoj tento postoj, túto víziu Magistéria Cirkvi, a stal sa jej autentickým nositelom.

Lassalleho poňatie spirituálneho dialógu sme opísali pomocou troch pojmov: akomodácia, zen pre krestanov a téza o univerzálnej povahe transcendentnej „skuisenosti“. Pochopitel'ne, zazen, ako metóda nepredmetnej meditácie, nie je pre každého - či už je to krestan, alebo buddhista. Prínos pátra Lassalleho sa zdaleka nevyčerpáva tým, že so súhlasom svojich predstavených ponúkol túto metódu krestanom. Jeho hlavným prínosom je skôr to, že neváhal vstúpit na neprebádané územie náboženskej skúsenosti inej duchovnej tradície a svoju skúsenost' reflektoval teologicky vo vztahu $\mathrm{k}$ medzináboženskému dialógu a teológii spirituality. Vyvinul mimoriadne úsilie, aby získal mimoriadnu kvalifikáciu a z pozície tejto mimoriadnej kvalifikácie - ako autorizovaný znalec zenu a jezuita s hlbokým poznaním katolíckej spirituality - prakticky ukázal a teoreticky odôvodnil, že sa "netreba obávat" konfliktu medzi krestanskou a zenovou spiritualitou. ${ }^{165}$

164 Nostra aetate, čl. 2.

165 Enomiya-Lassalle 1995, s. 26. 
Hugo Makibi Enomiya-Lassalle sa stal živým stelesnením dialógu duchovnej skúsenosti, sprítomnením koncilovej ekleziológie putujúcej Cirkvi, ${ }^{166}$ ktorá „smeruje k plnosti Božej pravdy "167 a na tejto ceste sa stretáva s inými pútnikmi, objavuje stopy jednej a tej istej pravdy a podla príkladu Boha vstupuje do dialógu spásy - toho dialógu, ktorý Boh vedie s ludstvom od počiatku času -, aby sa $\mathrm{v}$ ňom otvárala pre plnšie porozumenie Božej pravdy. ${ }^{168}$

166 Lumen gentium, čl. 48.

167 Dei verbum, čl. 8.

168 Dialóg a oblasovanie, čl. 33 - 41. 



\section{Mystika - styčný bod spirituálneho dialógu}

Niet pochýb o tom, že to, čo je spoločné, môže viest'k prijatiu toho, čo je odlišné, pochopitel'ne pod podmienkou, že je ako spoločné poznané, uznané a ocenené.

$\mathrm{K}$ spoločným znakom náboženstva patrí mystika. „Mystika je jav, ktorý religionistika opakovane nachádza vo všetkých velkých náboženstvách“169 - zdá sa, že „každé náboženstvo má svoje mystické vyjadrenie“. ${ }^{170}$ Mystické skúsenosti sú doložené tol'kými svedectvami a dosvedčené tolkými dôveryhodnými osobami, že o ich existencii nemožno rozumne pochybovat. Mystická skúsenost' sa ukazuje byt' skúsenostou vskutku všeludskou.

Hoci je kontext, v ktorom sa objavuje, nezriedka rozmanitý, skúsenost' sama vykazuje prekvapivé podobnosti. "Je pozoruhodné, že mystické skúsenosti z rôznych oblastí sveta a z rôznych náboženských tradícii sú, napriek odlišnému názvosloviu, až prekvapivo obdobné." "171

„Mystika je jedna proti pluralite náboženstiev,“" dôvodí preto filozof Slavomír Gálik, „lebo transcendentné póly rôznych náboženstiev sú nielen podobné, ale vel'mi pravdepodobne aj totožné. " 172 Benediktín David Steindl-Rast vidí

169 Holm 1998, s. 36.

170 Fiores, Goffi 1999, s. 553.

171 Heller, Mrázek 1988, s. 122.

172 Gálik 2006, s. 34. 
potom v mystike spoločné jadro náboženstva. ${ }^{173} \mathrm{~V}$ kontexte spirituálneho dialógu mystika môže figurovat ako styčný bod medzi jednotlivými účastníkmi tohto typu dialógu a ich pozíciami. Možnosti, ktoré tento prístup otvára, tu načrtneme na príklade hermeneutiky mystickej kontemplácie kontextualizovanej na pozadí vzt’ahu medzi mystikou a náboženskou inštitúciou a morfológie mystickej skúsenosti.

\subsection{Mystické jadro náboženstva}

V každom náboženstve sa objavuje napätie medzi jeho mystickou a inštitucionálnou dimenziou, konštatuje David Steindl-Rast vo svojom článku Mystické jadro organizovaného náboženstva. ${ }^{174}$ Pôvodná mystická skúsenost sa postupom času formalizuje a inštitucionalizuje, autor rozvíja svoju myšlienku dalej. Najprv sa formuje náboženská doktrína, etika a kult, neskôr sa etabluje náboženská inštitúcia. ${ }^{175} \mathrm{~V}$ živom náboženstve sú doktrína, etika a kult postavené do služieb mystiky. Steindl-Rast prirovnáva ich funkciu k zavlažovaciemu systému, ktorý rozvádza „živú vodu“ z mystického zdroja náboženstva do každodenného života. Jednotlivé náboženstvá sa od seba lišía podobne, ako sa líšia rôzne zavlažovacie systémy - niektoré systémy sú efektívnejšie ako iné, pričom ich výkon závisí od sta-

173 Steindl-Rast 1989, s. $11-14$.

174 Ibid., s. 11-14.

175 K rovnakým záverom prichádza aj filozof Slavomír Gálik (2006, s. 33): „pravdepodobne každé náboženstvo vzniklo z mystickébo pohybu, ale po čase, stublo, nabralo na seba nejakú inštitucionalizovanú podobu". 
vu aj veku systému, nakol'ko funkčnost’ systému obvykle časom klesá. Zo svojej pôvodnej podoby interpretácie základnej mystickej skúsenosti doktrína môže skostnatiet' do dogmatizmu. Morálka (ako obsah etiky), ktorá prepája základnú mystickú skúsenost’ s každodenným životom veriacich, sa môže sformalizovat' do podoby moralizmu. Kult, ktorý je pripomienkou a oslavou základnej mystickej skúsenosti, môže degradovat' na ritualizmus, ak forma prevládne nad obsahom.

Každé náboženstvo (lat. religio, $\mathrm{z}$ toho religiozita) sa zákonite inštitucionalizuje, pretože „religiozita je tradične a inštitucionálne ukotvená spiritualita", tvrdí Zdeněk Vojtíšek. ${ }^{176}$ Steindl-Rast ilustruje proces inštitucionalizácie náboženstva obrazom sopky. Počiatky vel'kých náboženstiev pripomínajú erupcie vulkánu - výbuch sopky sprevádza oheň, teplo, svetlo. Svetlo základnej mystickej skúsenosti nachádza svoj výraz v náboženskom učení (doktrína), teplo sa manifestuje ako morálny záväzok (premietnutý do etiky), oheň prechádza do oslavy (kult). Svetlo náuky, teplo morálky a oheň rituálu tryskajú $z$ mystickej skúsenosti podobne ako láva $z$ vulkánu. Ako sa však magma vzdaluje od svojho zdroja, nevyhnutne sa ochladzuje, tuhne a transformuje sa na horninu. Živá „skúsenost" transcendencie, vyjadrená v pôvodnej doktríne, etike a kulte, sa vytráca. Duch vyvanie, forma ostáva.

Kde-tu sa však môžu objavit trhliny vo vyvrenine, cez ktoré magma presakuje. Kde-tu prerazia horúce pramene a gejzíry, nastanú príležitostné zemetrasenia a erupcie $\mathrm{v}$ analógii k týmto geologickým procesom mystika interferuje s inštitúciou.

176 Vojtíšek 2012, s. 25. 
Príroda prirodzene vytvára štruktúry, kultúra prirodzene kreuje inštitúcie. Pomyslime len na dômyselnost', s akou príroda chráni semená rastlín, na všetky tie šupy, obaly a struky. Ale na rozdiel od štruktúr prírody, ktoré zanikajú, ked' splnia svoj účel, ludské štruktúry majú tendenciu uchovávat svoju existenciu. Náboženské inštitúcie sú ako struky, ktoré v sebe nesú, alebo by aspoň mali niest', semená nového života.

David Steindl-Rast nepochybuje o tom, že mystika môže rozpustit' rigor mortis dogmatizmu, moralizmu a ritualizmu v oživujúcej interakcii s náboženskou inštitúciou, lež cesta $\mathrm{k}$ mystickému jadru náboženstva nevedie po obvode kruhu vymedzeného náboženskými fenoménmi, ale smeruje do jeho stredu - od periférnych náboženských skúseností imanentnej povahy (intencionálne skúsenosti), k samotnej základnej mystickej „skúsenosti“ - k autentickej „skúsenosti“ transcendencie, ktorá je zo svojej povahy neintencionálnou „skúsenostou“.

\subsection{Morfológia mystickej skúsenosti}

Pre porozumenie mystiky je klúčové rozlíšenie medzi skúsenostou intencionálneho a neintencionálneho typu. Kým pre intencionálny typ skúsenosti je charakteristická prítomnost' sprostredkujúcich faktorov skúsenosti ako premenných, ktoré našu skúsenost̉ utvárajú, takpovediac konštruujú, a teda tiež vopred určujú alebo podmieňujú, či dokonca determinujú, pre neintencionálny typ skúsenosti je, naopak príznačná neprítomnost' sprostredkujúcich faktorov skúsenosti, čo spôsobuje, že skúsenost’ 
je nesprostredkovaná, a teda neskonštruovaná a nepodmienená. ${ }^{177}$

Dvom základným kategóriám skúsenosti zodpovedajú dve rámcové interpretačné paradigmy - konštruktivizmus a esencializmus (v dejinách známy skôr ako perenializmus, vo svojej aktuálnej podobe tiež ako neoesencializmus; v našej interpretácii postkonštruktivizmus, pretože v súčasnosti sa rozvíja prevažne v kritickej reakcii na konštruktivizmus). Zatial čo konštruktivizmus absolutizuje intencionálny typ skúsenosti a možnost' neintencionálnej skúsenosti celkom popiera, postkonštruktivizmus nahliada skúsenost’ v celku oboch jej základných modalít a argumentuje $\mathrm{v}$ prospech možnosti neintencionálnej skúsenosti. Vo vztahu k mystike sa konzekventne vyprofilovali dva konkurenčné modely mystiky - konštruktivistický a esencialistický (postkonštruktivistický) model mystiky.

Konštruktivistický model mystiky si nachádzal svojich priaznivcov postupne od 60. rokov 20. storočia (napríklad John Hick), až kým sa jeho hlavným protagonistom stal americký filozof Steven Katz, ked'v roku 1978 publikoval svoj programový článok Language, Epistemology and Mysticism. ${ }^{178}$ Katzove tézy a argumenty vyvolali vel'ký ohlas predovšetkým u Roberta Gimella a Petra Moora.

Steven Katz redukuje mystickú skúsenost' na iné formy ludskej skúsenosti. Pre jeho radikálnu formu konštruktivizmu sú charakteristické dve tézy - konštruktivistická téza

177 Podrobnú filozofickú analýzu intencionality a neintencionality obsahuje predchádzajúca monografia autora Sebatranscendencia: antropologický model (Dojčár 2017).

178 Katz „Language, Epistemology and Mysticism“ in Katz 1978, s. 22 - 74. 
o sprostredkovanej povahe každej skúsenosti a pluralistická téza o radikálnej pluralite mystických skúseností.

Katz, a s ním celé konštruktivistické hnutie, interpretuje skúsenost', vrátane mystickej skúsenosti, ako kognitívne sprostredkovanú, a teda podmienenú našimi predchádzajúcimi skúsenostami, postojmi, mentálnymi a kultúrnymi vzorcami, jazykom a inými podmieňujúcimi faktormi: „čistá“, teda nesprostredkovaná skúsenost̉ nejestvuje - jestvuje len mentálna konštrukcia či rekonštrukcia skúsenosti.

Hoci sa rozchádzajú v tom, akým spôsobom má byt skúsenost' podmienená, vo svojej teórii poznania konštruktivisti súhlasne vychádzajú z neokantovskej epistemológie, ktorú vzṫahujú paušálne na celý rozsah ludskej skúsenosti, mystickú skúsenost' nevynímajúc. Námietka kritikov konštruktivizmu preto smeruje ku jadru tejto teórie poznania a dá sa formulovat nasledovne: Skutočne nie je možné, aby popri sprostredkovanom type skúsenosti jestvovali aj nesprostredkované skúsenosti zoläśt', ak o nich referujú mystici naprieč náboženským spektrom?

Súčasní predstavitelia postkonštruktivizmu (neoesencializmus) postavili svoju kritiku konštruktivizmu na možnosti „čistej“, teda nesprostredkovanej skúsenosti a na tomto základe potom navrhli svoj esencialistický model mystiky. Donald Evans a Robert K. C. Forman zhodne tvrdia, že je možné transcendovat človeku vlastný intencionálny typ skúsenosti smerom k „skúsenosti“ neintencionálneho typu.

Evans vyvracia Katzovu tézu o zásadnej nedostupnosti „čistej“ nesprostredkovanej skúsenosti. Mystici dosvedčujú presne to, čo Katz popiera, tvrdí Evans, a totiž to, že človek môže poodstúpit od vlastného konceptuálneho myslenia a jeho jazykového vyjadrenia a otvorit sa pre 
skúsenost', ktorá nie je sprostredkovaná psychomentálne (neintencionálna „skúsenost' “). ${ }^{179}$

Centrálnou kategóriou neoesencialistického diskurzu je preto neintencionálna „skúsenost" ako udalost cistébo vedomia („Pure Consciousness Event", PCE) ${ }^{180}$ a jeho jadro spočíva $\mathrm{v}$ argumentácii $\mathrm{v}$ prospech transkultúrneho výskytu tejto „skúsenosti“. Presvedčenie o univerzálnom výskyte nesprostredkovanej „skúsenosti“ potom zakladá univerzalistickú tézu. ${ }^{181}$ Proti Katzovej pluralistickej téze takto Robert Forman postuluje vlastnú axiómu, svoj neosencialistický variant perenializmu, založený na presvedčení o univerzálnom výskyte nesprostredkovanej „skúsenosti“ (univerzalistická téza).

Udalost' cistého vedomia majú charakterizovat' dva znaky: neintencionalita a fenomenálna identita. Robert K. C. Forman definuje PCE ako stav „bdelébo, ale bezobsažného (neintencionálneho) vedomia“. ${ }^{182}$ Práve neintencionalitou, tým, že ,subjekt je bdelý, vedomý, ale bez objektu či obsahu vedomia“, ${ }^{183}$ sa má udalost cistého vedomia odlišovat od „bežnej“ skúsenosti, ktorá je svojím zameraním na predmet (intencionalita) vždy skúsenostou „niečoho“. $Z$ uvedeného dôvodu Forman zavádza termín, udalost' "cistého vedomia $\mathrm{v}$ protiklade $\mathrm{k}$ výrazu ,skúsenost', pretože ten predpokla-

179 Evans 1989, s. $53-60$.

180 Forman 2007, s. 72.

181 Bernhardt „Are Pure Consciousness Events Unmediated?“ in Forman 1990, s. $225-229$.

182 Forman „Introduction: Mysticism, Constructivism and Forgetting“ in Forman 1990, s. 8. Forman 2007, s. 71.

183 Bernhardt „Are Pure Consciousness Events Unmediated?“ in Forman 1990, s. 220. 
dá podvojnost' subjektu a objektu skúsenosti, ktorá je však transcendovaná v neintencionálnom type „skúsenosti“.

V roku 1990 vyšla pod názvom Problém čistébo vedomia: mystika a filozofia priekopnícka neoesencialistická zbierka štúdií venovaná obrane univerzalistickej tézy. ${ }^{184}$ Kým Katz, a s ním celé konštruktivistické hnutie tvrdí, že nejestvuje dôkaz o výskyte neintencionálnej „skúsenosti“, ${ }^{185}$ autori tejto zbierky naopak argumentujú v prospech transkultúrneho výskytu PCE. Štyri štúdie prvej kapitoly majú za úlohu preukázat výskyt $\mathrm{PCE} \mathrm{v}$ indických tradíciách sánkja a joga-daršana, ako aj v indickom buddhizme, $\mathrm{v}$ katolíckej mystike majstra Eckharta a v klasickej židovskej kabale. Autori štúdií druhej kapitoly ponúkajú filozofické argumenty v prospech možnosti neintencionálnej „skúsenosti“ a spochybňujú schopnost' konštruktivistov adekvátne vysvetlit kognitívny proces konštruovania mystických skúseností.

Zdokumentované prípady výskytu udalosti cistého vedomia sú následne, podla neoesencialistov, ,fenomenálne identické "186 v prípade, ,ak dva texty opisujú stavy bez predmetu“. ${ }^{187} \mathrm{~V}$ súlade s týmto metodologickým postulátom dalej ukážeme, ako neintencionalita a fenomenálna identita charakterizujú mystickú kontempláciu v dvoch mainstreamových tradíciách mystiky odlišnej historickej, kultúrnej a náboženskej proveniencie, presnejšie v katolíckej mystike anonymného stredovekého autora Oblaku nevedenia (14. storočie) a v advaita-védánte novovekého indického džňánina Ramana Maharšiho (1879 - 1950).

184 Forman 1990.

185 Katz „Language, Epistemology and Mysticism“ in Katz 1978, s. 57.

186 Bernhardt „Are Pure Consciousness Events Unmediated?" in Forman 1990, s. 223.

187 Ibid., s. 224. 


\subsection{Neintencionalita a fenomenálna identita mystickej kontemplácie}

V porovnávacej štúdii o mystickej kontemplácii v mystike Oblaku nevedenia a v advaita-védánte Ramana $\mathrm{Ma}-$ haršiho sme podrobili analýze a komparácii dve historicky, kultúrne a nábožensky vzdialené formy kontemplácie, aby sme preskúmali platnost' postkonštruktivistickej argumentácie. ${ }^{188}$ Závery nášho bádania tu zhrnieme nasledovne.

Aby kontemplácia priniesla očakávané výsledky, musia byt splnené určité podmienky. Podmienkou „krestanskej“ i „maharšiovskej“ kontemplácie sú mravná a koncentračná kvalifikácia ako dôsledok spôsobu života, ktorý je ovocím cielavedomého mravného úsilia. Vlastnou metódou kontemplácie je v jednom, aj v druhom prípade sústredenie.

Obaja učitelia kontemplácie ponúkajú vlastné praktické návody, ako dospiet od intencionálnej skúsenosti k neintencionálnej „skúsenosti“. Ich odporúčania sa rôznia v odlišných teoretických východiskách duchovných tradícií, ku ktorým patria, ale približujú vzhladom na konkrétne aspekty kontemplatívnej praxe, ktorú učia. Akokolvek sa líšia, jedno majú spoločné: pozornost treba odvrátit od jej samovolného toku k predmetom (intencionalita) a prostredníctvom sústredenia stabilizovat' na nespochybnitelnom fakte vlastnej existencie, aby v sebatranscendencii následne došlo k odkrytiu (gr. alétheia) neintencionality, ktorá sa z epistemologického hladiska ukazuje ako vôbec prvá podmienka možnosti každej intencionality. Pre stredove-

188 Dojčár 2008. 
kého anglického mystika Oblaku nevedenia je tažiskovou metódou kontemplácie láskyplné sústredenie sa na vlastné bytie (lat. esse) kontemplujúceho, ktoré odkazuje na bytie Boha (lat. esse, tiež actus essendi - akt bytia) ako jeho „stopa" v človeku; pre indického džňánina je to sebaskúmanie (skt. átmavičara) čoby pátravé naladovanie sa (skt. vičára) na transcendentný zdroj vlastnej existencie človeka (skt. átman).

Inými slovami, metóda Oblaku nevedenia „spočiva v jednoduchom rozpoznani a slepom [pozn. bezprostredno-skúsenostnom] prijati vlastnej existencie“. ${ }^{189} \mathrm{~K}$ zjednoteniu s Bohom dochádza práve skrze vedomie vlastnej existencie (lat. esse) ${ }^{190}$ Kontemplácia vrcholí v sebaprekračujúcom odovzdaní sa, ked' sa duša „v láske umenšuje a Boha vyvyšuje ako všetko vo všetkom". ${ }^{191}$

Aj Maharšiho metóda kontemplácie smeruje k prekročeniu individuality prostredníctvom sústredenia sa na fakt vlastného bytia, ktorý nemožno spochybnit'. Stále smerovanie pozornosti $\mathrm{k}$ tejto apodiktickej skúsenosti vlastnej existencie, spojené s pátravým naladovaním sa (skt. vičára) na jej transcendentný zdroj (skt. átman), tvorí podstatu átmavičary. ${ }^{192}$

Pre mystiku je príznačné napätie medzi skúsenostou a jej vyjadrením (gr. apofáza). Reč zlyháva pri opise nein-

189 Epistle of Privy Counsel in The Cloud of Unknowing, kap. 1, s. 161.

190 Ibid., kap. 9, s. 185.

191 Ibid., kap. 6, s. 178.

192 "The 'I'-thought is said to be the sum-total of all thoughts. The source of the 'I'-thought has to be enquired into." Maharshi 1966 (Sri Ramana Gita), 7, 3. "When the ego, which is mere reflection of the Self, totally disappears, what remains is the true Self alone in all its plenitude and perfection." Ibid., 7, 5 . 
tencionálnej „skúsenosti“ a zdá sa, že mlčanie je jediným adekvátnym výrazovým prostriedkom mystikov. Negatína cesta (lat. via negativa) je postupom „poza“ všetky pojmy a výrazy, je svedectvom o prekročení intencionality i jazyka, ktorý je na ňu viazaný. Nachádzame ju rovnako v učení Oblaku nevedenia i Ramana Maharšiho.

Oblak nevedenia uvádza na cestu zjednotenia s vždy väčším Bohom. Jeho ciel'om je „zjednotenie s Bohom v duchu, láske a v súlade vôle. "193 Opis stavu zjednotenia sa vymyká možnostiam jazyka, prekračuje hranice ludského chápania a hovorenia. Aj ked' ho opisuje ako dokonalost' a blaženost', anglický mystik vie, že každé tvrdenie o transcendentnej „skúsenosti“ je napokon neadekvátne. ${ }^{194}$

S výsledkami Maharšiho sebaskúmania je to podobné. Cielom átmavičary je enstáza - samádhi. V ňom sa odovzdané sebaskúmanie zhodnocuje tým, že otvára priestor pre oslobodzujúce poznanie (skt. džňána). Finálny duchovný stav sahadža-nirvikalpa-samádhi je stavom múdrosti, ${ }^{195}$ ktorá transcenduje utrpenie, ${ }^{196}$ prináša oslobodenie od strastiplnosti pozemskej existencie (skt. mókša) a nepodmienené naplnenie (skt. ánanda). ${ }^{197}$

Obe metódy kontemplácie majú nepredmetný, resp. predmetnost' prekračujúci charakter, pretože sa neuskutočňujú v médiu myslenia, či vztahovania sa $\mathrm{k}$ nejakému predmetu vedomia, ale v obracaní pozornosti na vedomie samotné cez nespochybnitelný fakt vlastnej existencie. Vyústením transcendujúceho pohybu kontemplácie je

193 The Cloud of Unknowing, kap. 67, s. 141.

194 Ibid., kap. 26.

195 „[W]isdom-insight (jnana-drsti)“. Maharshi 1966 (Who am I?), 25.

196 Maharshi 1966 (Sri Ramana Gita), 7, 6.

197 Maharshi 1966 (Who am I?), 28. 
v oboch prípadoch seba odovzdanie, ktoré kontemplujúcemu otvára neintencionálnu „skúsenoste “ ako autentickú „skúsenost" transcendencie a robí ju „neskrytou“ v zmysle starogréckeho filozofického ideálu alétheia.

Mystickú kontempláciu v katolíckej mystike Oblaku nevedenia a v indickej advaita-védánte Ramana Maharšiho charakterizuje neintencionalita. $V$ oboch prípadoch je finálna „skúsenost“, podla jej protagonistov, stavom bdelého, ale bezobsažného vedomia. Popri všetkých rozdieloch, ${ }^{198}$ obe historicky, kultúrne a nábožensky vzdialené podoby kontemplácie sa zdajú byt konkretizáciou udalosti čistébo vedomia (PCE). Na základe uvedeného metodologického princípu sú teda koncepty mystickej kontemplácie v mystike Oblaku nevedenia a v Maharšiho advaita-védánte fenomenálne identické.

198 Teoretické východiská, duchovné metódy, prostriedky a nástroje a pod. 


\section{Záver}

$\mathrm{Na}$ dohl’ad od majestátneho chrámu, týčiaceho sa vysoko nad rozlahlým benediktínskym opátstvom sv. Jána, v objatí malebného univerzitného areálu rovnomennej benediktínskej univerzity, s priečelím hrdo nastaveným blankytným vodám jazera Stumpf, rozkladá sa komplex budov Collegevillského inštitútu. Od svojho vzniku v roku 1967 inštitút vytvára priestor na stretnutie ludí rôznej náboženskej príslušnosti, rozličnej duchovnej orientácie, kultúrnej afiliácie, etnicity, rasy i národnosti. Za pol storočia svojej existencie sa stal vyhláseným centrom dialógu $\mathrm{v}$ jeho autentickej podobe - v tej podobe, akú sme krok za krokom sledovali $\mathrm{v}$ tejto knihe, a ktorá spočíva $\mathrm{v}$ osobnom stretnutí autonómnych osôb, v nadviazaní vztahu, vo vytvorení spoločenstva.

Svojím poslaním, rozvíjat medzikultúrny, medzináboženský a ekumenický dialóg na báze osobného stretnutia, sa inštitút v Collegeville radí medzi avantgardu svetového dialogického hnutia. Krehký balans medzi akademickým a komunitným životom z neho robí unikátne miesto na vzájomné zdiel'anie založené na dialogických princípoch vztahovosti a finality. Stovky účastníkov jeho rezidenčných a vzdelávacích programov svedčia o životaschopnosti tohto „laboratória dialógu“. Inštitút v americkom Collegeville založil tradíciu "stavania mostov“ medzi náboženstvami, spiritualitami, kultúrami, etni- 
kami, rasami i národnostami a potvrdzuje, že dialóg je možný a zmysluplný. ${ }^{199}$

Dialóg, ako stredná cesta medzi extrémnymi pozíciami lahostajnosti a xenofóbie, prináša nádej v protiklade $\mathrm{k}$ beznádeji, akú môže plodit súčasný geopolitický a spoločensko-kultúrny vývoj v mnohých krajinách sveta. Symbolom tejto nádeje je stretnutie. Dialóg ukazuje, že je možné, aby sa úplne odlišní ludia - etnicky, rasovo, národnostne, kultúrne, spoločensky, nábožensky a duchovne - stretli na báze rovnosti a hladali to, čo majú spoločné. Pretože dialóg nezdôrazňuje to, čo lududí rozdeluje, ale to, čo ich spája.

Apel na vztahovost' prelamuje hranice, vyhranenej individuálnosti vo všetkých podobách dialógu, ktorými sme sa tu zaoberali, spirituálny dialóg nevynímajúc. A práve vztahovost' robí $\mathrm{z}$ dialógu znamenie nádeje $\mathrm{v}$ našom beznádejne rozdelenom svete.

Spirituálny dialóg ponúka nové možnosti ako rozvijat vztahovost', otvára nové perspektívy vzájomného kontaktu, ked' obracia našu pozornost' od periférie našej každodennej skúsenosti (intencionálna skúsenost') k jej oživujúcemu zdroju - k základnej mystickej „skúsenosti“, ktorá je svojou povahou neintencionálnou „skúsenostou“.

199 Collegeville Institute 2021. 


\section{Bibliografia}

„Ad gentes." In Dokumenty Druhého vatikánskeho koncilu II. 1993. Trnava: SSV.

Arrupe, Pedro. 1992. Misionár v Japonsku. Trnava: SSV. Buber, Martin. 2001. Problém člověka. Praha: Kalich.

Buber, Martin. 2005. Já a ty. Praha: Kalich.

Bučko, Ladislav. 2003. Na ceste $k$ oslobodeniu: základy misiológie. Nitra: SVD.

Collegeville Institute. 2021. Navštívené 1. januára 2021. https://collegevilleinstitute.org/residencies/resident-scholars/former-scholars/.

„Dei verbum." In Dokumenty Druhého vatikánskeho koncilu I. 1993. Trnava: SSV.

Dialóg a oblasovanie. 2001. Bratislava: ÚVSC.

Dojčár, Martin. 2018. „An Interview with William Skudlarek: Interreligious Dialogue Emphasizes an Experiental Knowledge of Other Spiritual Paths." Spirituality Studies 4 (2), s. 30 - 31.

Dojčár, Martin. 2017. Sebatranscendencia: antropologický model. Trnava: Dobrá kniha.

Dojčár, Martin (ed.). 2016. Religiofóbia: realita, prevencia a edukácia. Trnava: Trnavská univerzita.

Dojčár, Martin. 2013. „The Phenomenon of Consciousness from the Perspective of Comparative Study of Mysticism: A Challenge for Interreligious and Interspiritual Understanding." Studies in Spirituality 23, s. $1-11$. 
Dojčár, Martin. 2012. Problém globálneho spolužitia: antropologické rúchodisko. Trnava: Veda.

Dojčár, Martin. 2010. Medzináboženský dialóg II. Trnava: Trnavská univerzita.

Dojčár, Martin. 2008. Mystická kontemplácia: Oblak nevedenia \& Ramana Maharši. Bratislava: Iris.

Ján Pavol II. 1997. Redemptoris missio. Trnava: SSV.

Enomiya-Lassalle, Hugo Makibi. 1995. Zenová meditace. Brno: Cesta.

Evans, Donald. 1989. „Can Philosophers Limit What Mystics Can Do? A Critique of Steven Katz." Religious Studies 25 (1), s. 53 - 60.

Fiorenza, Francis S., John P. Galvin. 1996. Systematická teologie I. Brno: CDK.

Fiores, Stefano de, Tullo Goffi. 1999. Slovnik spirituality. Kostelní Vydří: Karmelitánské nakladatelství.

Floss, Karel, Pavel Hošek, Ivan Štampach, Zdeněk Vojtíšek. 2008. Cesty k porozuméni jinému: teologie, religionistika a mezináboženský dialog v pojetí Wilfreda Cantwella Smithe. Praha: Dingir.

Forman, Robert K. C. (ed.). 1990. The Problem of Pure Consciousness: Mysticism and Philosophy. New York: Oxford University Press.

Forman, Robert K. C. 2007. „What Does Mysticism Have to Teach Us About Consciousness?" AntiMatters 1 (2), s. $71-89$.

Foucauld, Charles de. 1998. Boh je láska. Bratislava: Oto Németh.

Gálik, Slavomír. 2006. Filozofia a mystika. Bratislava: Iris. „Gaudium et spes.“ In Dokumenty Druhého vatikánskeho koncilu I. 1993. Trnava: SSV. 
Grenz, Stanley. 1997. Úvod do postmodernismu. Praha: Návrat domů.

Gulán, Tomáš (ed.). 2011. Apoštol Pavol pre 21. storočie. Žilina: Žilinská univerzita.

Halík, Tomáš. 2002. Co je bez chvèní, neni peoné. Praha: NLN.

Heller, Jan, Milan Mrázek. 1988. Nástin religionistiky. Praha: Kalich.

Holm, Nils G. 1998. Úvod do psychologie náboženství. Praha: Portál.

Huntington, Samuel P. 2001. Střet civilizaci: boj kultur a promèna svètového rádu. Praha: Rybka Publishers.

Johnston, William. 1997. Hledáni nové spirituality. Brno: Portál.

Kaisen, Sandó. 2018. „Grand Faith.“ Spirituality Studies 4 (2), s. $30-31$.

Katz, Steven T. (ed.). 1978. Mysticism and Philosophical Analysis. New York: Oxford University Press.

Lafon, Michel. 2000.15 dni s Karlem de Foucauldem. Brno: Cesta.

Lehman, Karl. 1996. „Dialog jako forma komunikace v církvi dnes." Teologické texty 7 (1), s. 2 - 6.

Lenoir, Frédéric. 2003. Setkávani buddhismu se západem. Praha: Volvox Globator.

Leuenberg Church Fellowship. 2001. „Church and Israel: A Contribution from the Reformation Churches in Europe to the Relationship between Christians and Jews." Navštívené 1. januára 2021. https://www.jcrelations.net/article/church-and-israel-a-contributionfrom-the-reformation-churches-in-europe-to-the-relationship-between-christians-and-jews.pdf. 
Lipovetsky, Gilles. 2007. Paradoxní šsěstí. Praha: Prostor. Liptay, Lothar. 2000. Vztáab krestanstva k iným náboženstvám. Bratislava: Univerzita Komenského.

„Lumen gentium." In Dokumenty Druhého vatikánskeho koncilu I. 1993. Trnava: SSV.

Lužný, Dušan. 1997. Nová náboženská hnutí. Brno: Masarykova univerzita.

Macháčková, Lucia, Martin Dojčár. 2002. Duchovná scéna na Slovensku II. Bratislava: ÚVSC.

Maharshi, Ramana. 1966. Who am I? Tiruvannamalai: Sri Ramanasramam.

Maharshi, Ramana. 1966. Sri Ramana Gita. Tiruvannamalai: Sri Ramanasramam.

Mráz, Marian. 1999. Problém utrpenia a jeho riešenie v medicinskej etike. Trnava: Dobrá kniha.

Nešpor, Zdeněk. 2020. Česká a slovenská religiozita po rozpadu spoločnébo státu. Praha: Karolinum.

„Nostra aetate." In Dokumenty Druhého vatikánskeho koncilu II. 1993. Trnava: SSV.

Palouš, Radim. 1993. „K spiritualitě postmoderny.” Teologické texty 1, s. 12.

Patanjali. „Yoga Sutras.“ In Woods, James H. 1998. The Yoga-System of Patanjali. Dehli: Motilal Banarsidass.

Pavol VI. 1968. Ecclesiam suam. Rím: SÚCM.

Pavol VI. 1964. „Address of Pope Paul VI to the Members of the Non-Christian Religions." Navštívené 1. januára 2021. https://www.vatican.va/content/paul-vi/en/ speeches/1964/documents/hf_p-vi_spe_19641203_ other-religions.html.

Pew Research Center. 2017. „The Changing Global Religious Landscape." Navštívené 1. januára 2021. https://assets.pewresearch.org/wp-content/uploads/ 
sites/11/2017/04/07092755/FULL-REPORTWITH-APPENDIXES-A-AND-B-APRIL-3.pdf.

Pew Research Center. 2011. „Global Christianity.“ Navštívené 1. januára 2021. https://assets.pewresearch. org/wp-content/uploads/sites/11/2011/12/Christianity-fullreport-web.pdf.

Poláková, Jolana. 1998. „Několik poznámek ke smyslu dialogu." Filosofický casopis 46 (3), s. 465 - 472.

Pontifical Council for Promoting Christian Unity. 2015. „The Gifts and the Calling of God are Irrevocable." Navštívené 1. januára 2021. http://www.christianunity.va/content/unitacristiani/en/commissione-per-i-rapporti-religiosi-con-1-ebraismo/commissione-per-i-rapporti-religiosi-con-1-ebraismo-crre/ documenti-della-commissione/en.html.

Průcha, Jan. 2004. Interkulturni psychologie. Praha: Portál. Ricoeur,Paul.1993.Život, pravda, symbol.Praha: Oikoymenh. Sekty z pohledu cirkvi v Evropè. 1998. Praha: Pastorační středisko při Arcibiskupství pražském.

Steindl-Rast, David. 1989. „The Mystical Core of Organized Religion." ReVision 12, s. $11-14$.

Sväté pismo starého a nové zákona. 1995. Rím: SÚCM.

Šoltés, Radovan. 2021. Starost'o dušu v súčasnom svete. Prešov: Prešovská univerzita.

Štampach, Ivan. 1998. Náboženstvív dialogu: kritickéstudie na pomezi religionistiky a teologie. Praha: Portál.

Štampach, Ivan. 1998. „Sekty - fenomén na prahu tretieho tisícročia (2).“ Rozmer 2, s. 7.

Štampach, Ivan. 1993. Život, Duch a visechno. Tišnov: Sursum. The Cloud of Unknowing and Other Works. Translated into Modern English with an Introduction by Clifton Wolters. 1982. Harmondsworth: Penguin. 
Vojtíšek, Zdeněk. 1998. Netradiční náboženstuí u nás. Praha: Dingir.

Vojtíšek, Zdeněk, Pavel Dušek, Jiř́i Motl. 2012. Spiritualita v pomáhajicich profesich. Praha: Portál.

Waldenfels, Bernhard. 1998. Znepokojivá zkušenost cizího. Praha: Oikoymenh.

Wehr, Gerhard. 1999. Mistr Eckhart. Olomouc: Votobia. 


\section{Register}

A

Advaita-védánta 98, 99, 102

Akomodácia 44, 51, 72, 73, 88

Animozita 8, 21, 22

Antijudaizmus 21, 56, 58, 60

Antisemitizmus 56, 58, 60

Apofatizmus 80, 81, 100, 101

Arrupe, Pedro 72, 77, 79, 80

Askéza 48

Átman 100

Átmavičara 100, 101

Autonómia 26, 27, 28, 30, 31, 38, 39, 61, 103

B

Benedikt XVI. 60, 61, 64

Benediktíni 5, 34, 46, 49, 54, 69, 91

Boží obraz, pozri Imago Dei

Buber, Martin 27, 28

Buddhizmus 16, 48, 49, 50, 51, 52, 53, 54, 73, 76, 77, 78,

$81,82,83,84$

Bytie 82, 86, 87, 100

C

Collegeville Institute 5, 103 
D

Dalajláma 14. Tändzin Gjamccho 49, 54

Dhjána 74

Dialóg 5, 6, 9, 12, 23, 25, 26, 27, 28, 29, 30, 31, 32, 33, 34, $35,36,37,39,40,41,42,46,47,48,49,54,55,58,59$, $60,61,62,63,64,65,66,67,69,70,71,72,73,74,82$, $88,89,92,103,104$

Dialóg a ohlasovanie $35,36,37,40,69,71$

Dialogický étos 12, 23, 25, 29, 30, 37, 38, 39, 67

Dialogický spôsob existencie 36, 37, 39, 65, 66, 67

DIMMID, pozri Mníšsky medzináboženský dialóg

Dokonalost' 87, 101

Dôstojnost' osoby 27, 30, 31, 38, 39

Druhý vatikánsky koncil 32, 35, 36, 41, 46, 47, 53, 57, 59, $60,62,63,69,71$

Džñána 101

E

Eckhart 85, 98

Ego 76, 82, 87

Enomiya-Lassalle, Hugo Makibi 6, 52, 53, 54, 70, 71, 72, $73,74,75,76,77,78,79,80,81,82,83,84,85,86,87$, 88,89

Esencializmus 95, 96, 97, 98

Esencialistický model mystiky, pozri Postkonštruktivistický model mystiky

Etika 28, 92, 93

F

Fenomenológia náboženstva 15

Fenomenálna identita 97, 98, 99, 102

Filozofia dialógu 31 
Forman, Robert K. C. 86, 96, 97, 98

Foucauld, Charles de 65, 66, 67, 70

František 42, 60, 61, 64

G

Globalizácia 7, 8, 66, 67

$\mathbf{H}$

Hermeneutická religionistika 70, 92

Hinduizmus 7, 11, 41, 45, 46, 47, 48

Humanita 23

Huntington, Samuel P. 9, 10, 11

I

Imago Dei 36, 38, 39

Insight 101

Intencionalita 76, 86, 94, 95, 96, 97, 99, 101, 104

Islam 7, 11,50, 56, 56, 61, 62, 63, 64, 78

Islamofóbia 21

J

Jamada, Kóun 52, 73

Jasutami, Hakuun Rjóko 52, 73

Ján Pavol II. 33, 55, 60, 61

Ján XXIII. 35, 57, 58

Ján z Kríža 84, 85

Jezuiti 44, 47, 50, 51, 52, 53, 54, 70, 71, 72, 84, 88

Joga $74,75,77,80,98$

Joga sútry 77

Joga-daršana $74,77,98$

Judaizmus $7,58,59,60,61$ 
K

Katz, Steven 95, 96, 97, 98

Kenšó 80

Komunikácia 25, 26, 27, 29, 30, 31, 37, 39

Koncentrácia 77, 78, 84, 99, 100

Konflikt civilizácií 9, 10, 11

Konštruktivizmus 14, 95, 96, 98

Konštruktivistická téza 95, 96

Konštruktivistický model mystiky 95, 96

Kontemplácia 65, 74, 80, 83, 84, 85, 86, 87, 92, 98, 99, 100, 101, 102

Konzumný étos 41, 67, 68

Krestanstvo 7, 11, 30, 38, 42, 43, 44, 45, 50, 52, 53, 55, 56, $59,61,64,65,66,72,78,80,81,84,85,88$

L

Láska 86, 97, 100, 101

M

Maharši, Ramana 98, 99, 100, 101, 102

Meditácia 74, 81, 83, 84, 85, 88

Medzináboženský dialóg 5, 6, 30, 31, 33, 34, 36, 37, 39, 40, $41,46,57,60,69,71,88,103$

Misia 30, 31, 34, 36, 37, 41, 42, 43, 44, 45, 48, 50, 51, 52, $545,67,72$

Mnišsky medzináboženský dialóg 5, 34, 69

Modlitba 60, 71

Morálka, mravnost' 12, 14, 20, 23, 29, 39, 67, 77, 80, 93

Moslim 8, 56, 61, 62, 63, 64, 65, 66, 68

Múdrost' 101

Multikultúrna civilizácia 9, 11, 56

Mystická kontemplácia 98, 99, 102 
Mystika 6, 82, 91, 92, 93, 94, 95, 96, 98, 99, 100, 101, 102

$\mathbf{N}$

Negatívna teológia, pozri Apofatizmus

Neintencionalita 85, 86, 94, 96, 97, 98, 102

Neintencionálna „skúsenost“ 86, 94, 95, 96, 97, 98, 99, 102, 104

Nepredmetná meditácia 83, 85, 88, 101

Nová religiozita 15, 16, 17, 18, 19, 20

Numinosum, pozri Sacrum

O

Oblak nevedenia 85, 86, 87, 98, 99, 100, 101, 102

Ohlasovanie, pozri Misia

Oslobodenie 76, 101

$\mathbf{P}$

Pataňdžali 74,77

Pavol VI. 34, 35, 47, 57, 58

Perenializmus, pozri Postkonštruktivizmus

Personalita 26, 27, 30, 83

Planetárna civilizácia 7, 8, 9, 12, 13

Pluralistická téza 96, 97

Postkonštruktivizmus 82, 86, 95, 96, 99

Postkonštruktivistický model mystiky 95, 96

Posvätno, pozri Sacrum

Pránajáma 75

Predmetná meditácia, pozri Rozjímanie

Primordiálna subjektivita 30, 76, 87

PCE, pozri Udalost' čistého vedomia 
$\mathbf{R}$

Religiofóbia 21

Rinzai 73, 78, 79

Rozjímanie 83

$\mathbf{S}$

Sacrum 15

Samádhi 80, 101

Sanbó Kjódan 51, 52, 73

Satori 79, 80, 81, 82

Sebatranscendencia 87,99

Sekretariát pre nekrestanov 34, 36, 57, 64

Skudlarek, William 5, 69

Sótó $52,73,78,79$

Spiritualita 16, 49, 52, 53, 54, 73, 83, 85, 88, 93

Spirituálny dialóg 6, 9, 47, 69, 70, 71, 72, 73, 88, 91, 92, 104

Spoločnost' Ježišova, pozri Jezuiti

Steindl-Rast, David 49, 54, 70, 91, 92, 93, 94

Súcno 87

Sústredenie, pozri Koncentrácia

$\mathrm{T}$

Teologický dialóg 71

Transcendencia 20, 93, 94, 102

Transcendentná „skúsenost" $74,80,81,82,83,85,86,87$, 88,101

U

Udalost čistého vedomia 86, 97, 98, 102

Unio mystica 87

Univerzalistická téza 82, 83, 85, 88, 97, 98 
V

Védánta, pozri Advaita-védánta

Vedomie 74, 75, 76, 77, 78, 81, 85, 86, 97, 98, 100, 101, 102

Vzájomnost', pozri Vztahovost'

Vzt'ahovost' 27, 28, 29, 30, 37, 41, 67, 103, 104

\section{Z}

Zen $51,52,54,73,74,75,76,77,78,79,80,81,82,83$, $84,87,88$

Židovstvo, pozri Judaizmus

Zazen 54, 74, 75, 76, 77, 79, 80, 88

Zen-buddhizmus 52, 54, 73, 77

Zen pre krestanov 74,88

$\mathrm{X}$

Xenofóbia 8, 20, 21, 22, 23, 29, 56, 104 
Kniha, ktorú beriete do rúk, je syntézou desiatok rokov angažovaného bádania autora v oblasti spirituálneho dialógu. Na pozadí aktuálnych výziev doby (kap. 1 Planetárna civilizácia) v nej nájdete náčrt kontúr spirituálneho dialógu (kap. 4 Spirituálny dialóg) zakomponovaný do celkového obrazu dialógu (kap. 2 Dialogický étos), ktorého podobu dokresluju perspektívy dialógu v náboženskej oblasti (kap. 3 Perspektivy medzináboženského dialógu) a portréty, či skôr skice niektorých jeho významných osobností. Jednotlivé motivy autorovho obrazu spirituálneho dialógu sa napokon zbiehajú v centrálnom motive, ktorým je preň mystika ako styčný bod dialógu duchovnej skúsenosti (kap. 5 Mystika - styčný bod spirituálneho dialógu).

Odkaz tejto knihy sa dá zhrnút' do niekolkých slov: je to stretnutie a spoločné putovanie. A tým chce aj kniha predovšetkým byt': pozvaním na stretnutie a spoločné putovanie ludí rôznej náboženskej a duchovnej orientácie.



